\author{
UNIVERSIDADE DE BRASÍLIA - UNB \\ FACULDADE DE CIÊNCIAS DA SAÚDE - FS \\ PROGRAMA DE PÓS-GRADUAÇÃO EM ENFERMAGEM - PPGENF
}

HENRIQUE COIMBRA GUIMARÃES

\title{
A PROMOÇÃO DA SAÚDE DOS PORTADORES DE HIV/AIDS EM SITUAÇÃO PRISIONAL: ESTUDO SOB O OLHAR DO MODELO DE NOLA PENDER
}

Dissertação apresentada como requisito parcial para obtenção do título de Mestre em Enfermagem, pelo Programa de Pós-Graduação em Enfermagem da Universidade de Brasília.

Área de Concentração: Cuidado, Gestão e Tecnologias em Saúde e Enfermagem.

Linha de Pesquisa: Processo de Cuidar em Saúde e Enfermagem.

Orientadora: Prof. ${ }^{a}$ Dr. ${ }^{a}$ Moema da Silva Borges

BRASÍLIA - DF 
HENRIQUE COIMBRA GUIMARÃES

\title{
A PROMOÇÃO DA SAÚdE DOS PORTADORES DE HIV/AIDS EM SITUAÇÃO PRISIONAL: ESTUDO SOB O OLHAR DO MODELO DE NOLA PENDER
}

\author{
Dissertação apresentada como requisito parcial para a obtenção do título de Mestre \\ em Enfermagem, pelo Programa de Pós-Graduação em Enfermagem da \\ Universidade de Brasília.
}

Aprovada em 04 de agosto de 2016.

BANCA EXAMINADORA

Professora Doutora Moema da Silva Borges - Presidente da Banca Universidade de Brasília - Campus Darcy Ribeiro

Professora Doutora Diana Lúcia Moura Pinho - Membro Efetivo

Universidade de Brasília - Campus Darcy Ribeiro/ Ceilândia

Professora Doutora Tânia Cristina Morais Santa Bárbara - Membro Efetivo Universidade de Brasília - Campus Ceilândia

Professora Doutora Débora Luiza de Oliveira Rangel - Membro Suplente Universidade de Brasília - Campus Darcy Ribeiro 
Dedico este trabalho, primeiramente a Deus, por ser essencial em minha vida e estar sempre ao meu lado, me guiando e me dando força e coragem durante toda esta longa jornada.

À minha querida mãe, Elaine Coimbra, pelo exemplo em educação e profissionalismo, e por me orientar, incentivar $e$ apoiar sempre, em todas as minhas escolhas. 


\section{AGRADECIMENTOS}

Ao final dessa intensa jornada de trabalho, agradeço a Deus, por estar sempre ao meu lado, permitir a concretização dessa etapa da minha vida, e sempre atender meus pedidos $e$ anseios...

Agradeço à minha mãe, por ser minha maior incentivadora e também meu porto seguro! Sem você nada disso seria possível. Você é a melhor mãe do mundo.

Agradeço aos meus queridos irmãos, pelo incentivo e por sempre acreditarem em mim!

Agradeço à família da D. Geni por sempre estarem na torcida, me apoiando e incentivando. Vocês também foram fundamentais para a realização deste sonho.

Um agradecimento especial à minha orientadora: Professora Doutora Moema da Silva Borges. Professora, agradeço por acreditar no meu potencial e me permitir chegar até aqui...

Aos meus amigos, em especial à Monalisa, obrigado pelas palavras de incentivo e por compreenderem os momentos ausentes.

Agradeço também aos meus queridos colegas de mestrado, pelos incentivos e companheirismo! Nós conseguimos!

Agradeço aos meus chefes, por me incentivarem e compreenderem os momentos ausentes, permitindo a conclusão deste trabalho.

Aos colegas de trabalho do Complexo Penitenciário da Papuda, que me ajudaram grandemente durante todo este período... Em especial às enfermeiras Maria da Cruz e Isaura, que não mediram esforços para a realização da coleta de dados; e também à odontóloga Caroline e aos médicos Rafael e Ana, por estarem me incentivando e sempre dispostos a me orientarem nos momentos de dúvida. 
Ninguém educa ninguém, ninguém educa a si mesmo, os homens se educam entre si, mediatizados pelo mundo.

Paulo Freire 


\section{RESUMO}

GUIMARÃES, H.C. A promoção da saúde dos portadores de HIV/Aids em situação prisional: estudo sob o olhar do Modelo de Nola Pender. 2016. 121 f. Dissertação (Mestrado em Enfermagem) - Departamento de Enfermagem, Faculdade de Ciências da Saúde, Universidade de Brasília, Brasília, 2016.

No mundo todo, os níveis de infecção por HIV/Aids entre a população privada de liberdade tendem a ser bem mais altos do que entre a população fora dos ambientes prisionais, e esta situação agrava-se devido à superpopulação instalada, à precariedade da estrutura física e à lugubridade dos estabelecimentos penais, que, relacionadas a outros fatores, favorecem a disseminação da doença e de outros agravos, representando, assim, uma ameaça à saúde pública. Para que se possa viver melhor com HIV/Aids, é necessário almejar uma melhor qualidade de vida por meio da adoção de comportamentos de promoção da saúde e da busca de superar os impactos e limitações provenientes da doença, que atingem todas as dimensões humanas. Objetiva-se, nesta pesquisa, investigar comportamentos de promoção da saúde das pessoas privadas de liberdade portadoras de HIV/Aids no Complexo Penitenciário do Distrito Federal - Papuda. Trata-se de uma pesquisa social em saúde, exploratória e descritiva, baseada na abordagem qualitativa, interpretada à luz da Teoria da Promoção da Saúde, de Nola Pender. Para a coleta de dados, foi utilizado um instrumento organizado em duas partes, sendo a primeira um questionário com perguntas relacionadas ao perfil sociodemográfico e de saúde dos participantes, e a segunda constituída por um roteiro de entrevista semiestruturado, sequenciado e elaborado de acordo com a teoria de Nola Pender. As entrevistas foram realizadas durante o mês de agosto de 2015. Os dados obtidos por meio das entrevistas foram transcritos e o corpus destas submetidos à análise de conteúdo com auxílio do software Alceste. Foram entrevistados 12 participantes, reclusos no Presídio do Distrito Federal II. Da análise de conteúdo das entrevistas emergiram dois eixos. O primeiro eixo denominado, "HIV/Aids no cárcere: vulnerabilidades, diagnóstico, tratamento e barreiras existentes", faz menção ao HIV/Aids e foi composto por três categorias que dizem respeito aos comportamentos individuais anteriores à infecção, o diagnóstico, o tratamento e as barreiras existentes para a adoção de comportamentos de promoção da saúde na prisão. O segundo, "Percepção acerca da promoção da saúde", foi composto por duas categorias e faz menção à promoção da saúde, qualidade de vida e hábitos saudáveis adotados pelos participantes. Os resultados apontam que, apesar das inúmeras barreiras existentes dentro do sistema penitenciário, essa população reconhece a importância da adoção de alguns hábitos saudáveis. Busca sempre que possível praticá-los, pois demonstram positividade e autoeficácia em relação aos mesmos, uma vez que percebem benefícios como melhora no bem-estar, ganho de peso, melhora no sono, e na qualidade e expectativa de vida. $\mathrm{O}$ estudo apontou também que a enfermagem dispõe de um modelo/teoria próprio, que provou ser objetivo, de fácil entendimento, prático e abrangente. Assim, destaca-se a necessidade dos enfermeiros reconhecerem a importância das bases teóricas para o fortalecimento científico da profissão e, dessa forma, prestar uma assistência integral e resolutiva, por meio da aplicação da teoria de Nola Pender para subsidiar o planejamento de ações de promoção da saúde.

Palavras-chave: HIV; Síndrome da Imunodeficiência Adquirida; Teoria de Enfermagem; Promoção da Saúde; Prisões. 


\begin{abstract}
Worldwide, the level of HIV/AIDS infection among prisoners tends to be much higher than in the wider population outside prisons. This situation is worsened by the conditions inside prisons, such as overpopulation, the limitations of the physical structure and the lurid nature of prisons. In addition to other factors, these facilitate the spread of HIV/AIDS and other diseases, therefore representing a threat to public health. In order to live better with HIV / AIDS, it is necessary to aim for a better quality of life. This can be achieved by adopting behaviors of health promotion and by seeking to overcome the impacts and limitations imposed by the disease, which affect the physical, social and personal aspects of life. The aim of this research is to investigate the behaviors of health promotion undertaken by people deprived of their liberty living with HIV/AIDS in the Penitentiary of the Federal District Papuda. It is a social health study, both exploratory and descriptive, based on a qualitative approach, and interpreted using the Health Promotion Theory by Nola Pender. To collect data, we used an organized instrument into two parts, the first was consist of a questionnaire with questions related to sociodemographic and health, and the second part comprising the semistructured interview guide, sequenced and prepared in accordance with the theory Nola Pender. The interviews were conducted during the month of August 2015 and data obtained from the interviews were transcribed and submitted for content analysis using the Alceste software. Twelve participants, inmates in the prison of the Federal District II. In the analysis of the content of the interviews, two axes emerged. The first axis is "HIV/AIDS in the prison: vulnerabilities, diagnosis, treatment and obstacles". This is directly related to HIV/AIDS infection and was composed of three categories. These relate to individual behaviors prior to infection, the diagnosis and treatment of the disease and existing barriers to adopting behaviors of health promotion in prison. The second axis: "Perception about health promotion" was composed of two categories concerning promotion of health. These are quality of life, and healthy habits adopted by the participants. The results show that, despite the many barriers within the prison system, the population recognizes the importance of adopting some healthy habits, and tries to practice them whenever possible. After adopting these habits, participants experienced improved positivity and self-efficacy as a result of noticing benefits such as improved health, weight gain, improved sleep, as well as quality of life and life expectancy. In addition to this, it was demonstrated that nursing has its own model/theory that proved to be objective, easy to understand, practical and comprehensive. Thus, it highlighted the need for nurses to recognize the importance of the theoretical basis behind the scientific strengthening of the profession. In this way, through the application of Nola Pender's theory to the planning of health promotion actions, nurses can provide integral and resolutive assistance to patients.
\end{abstract}

Keywords: HIV; Acquired Immunodeficiency Syndrome; Nursing Theory; Health Promotion; Prisons. 


\section{RESUMEN}

A nivel mundial, los niveles de VIH / SIDA entre los presos tienden a ser mucho más alto que en la población em libertad y esta situación se ve agravada por la sobrepoblación instalada, la precariedad de la estructura física y lugubridad de las prisiones, que se relacionan con otros factores que favorecen la propagación de la enfermedad y otras enfermedades, por lo que representa una amenaza para la salud pública. Con el fin de vivir mejor con el VIH / SIDA, es necesario apuntar a una mejor calidad de vida mediante la adopción de conductas de promoción de la salud y tratar de superar los impactos y las limitaciones de la enfermedad, que afectan al aspecto físico, social y el personal. El objetivo principal, en esta investigación, es detectar los comportamientos que promueven la salud de las personas privadas de libertad con VIH / SIDA en la Penitenciaría del Distrito Federal - Papuda. Se trata de um estudio social de la salud, exploratorio y descriptivo, basado en el enfoque cualitativo, interpretado a la luz de la teoría de Promoción de la Salud, Nola Pender. Para la recopilación de datos, fué utilizado un instrumiento organizado en dos partes, siendo la primera una encuesta com preguntas relacionadas al perfil sociodemográfico y de salud e la segunda parte constituída por un rotero de entrevista semiestructurada secuenciada y preparada de acuerdo con la teoría de Nola Pender, siendo las entrevistas realizadas en el mes de agosto de 2015. Los datos obtenidos de las entrevistas fueron transcritas y el corpus de éstos sometidos a análisis de contenido utilizando el software Alceste. Se entrevistaron 12 participantes, presos en la prisión del Distrito Federal II. En las entrevistas, en el análisis del contenido surgieron dos ejes: El primer eje, el "VIH / SIDA en la vulnerabilidad de la prisión, el diagnóstico, el tratamiento y las barreras, hace mención de VIH / SIDA y está compuesto de tres categorías relacionadas con los comportamientos individuales antes de la infección, el diagnóstico, el tratamiento y las barreras existentes para la adopción de conductas de promoción de la salud en la cárcel. El segundo eje, la percepción acerca de la promoción de la salud, está compuesto de dos categorías y menciona la promoción de la salud, calidad de vida y hábitos saludables adoptada por los participantes. Los resultados muestran que, a pesar de los muchos obstáculos dentro del sistema penitenciario, la población reconoce la importancia de adoptar algunos hábitos saludables, e intentan siempre que sea posible practicarlos pues demuestran la positividad y la auto-eficacia en relación a ellos, una vez que perciben beneficios tales, como, la mejora en la salud, el aumento de peso, mejora del sueño, la calidad y esperanza de vida. Aún así, se ha descubierto que la enfermería tiene un modelo / teoria propio, que resulta ser objetivo, fácil de entender, práctico y completo. Por lo tanto, existe la necesidad de que los enfermeros reconozcan la importancia de la base teórica para el fortalecimiento de la profesión científica y por lo tanto proporcionen una asistencia integral y de resolución de problemas a través de la aplicación de la teoría de Nola Pender para la planificación de acciones de promoción de la salud.

Palabras clave: VIH; Síndrome de Inmunodeficiencia Adquirida; Teoria de Enfermería; Promoción de la Salud; Cárceles. 


\section{LISTA DE FIGURAS}

FIGURA 1 - DIAGRAMA DO MODELO DE PROMOÇÃO DA SAÚDE, DE NOLA J. PENDER.

FIGURA 2 - DENDOGRAMA DO CORPUS DAS ENTREVISTAS ORGANIZADO EM DOIS EIXOS E CINCO CLASSES. BRASÍLIA, 2016.

FIGURA 3 - MODELO DE PROMOÇÃO DA SAÚDE DE NOLA PENDER ADAPTADO PARA OS PORTADORES DE HIV/AIDS EM PRIVAÇÃO DE LIBERDADE. BRASÍLIA, 2016 96 


\section{LISTA DE TABELAS}

TABELA 1 - CARACTERIZAÇÃO DOS PARTICIPANTES QUANTO À IDADE, ORIENTAÇÃO SEXUAL E ESTADO CIVIL. BRASÍLIA, 2016......................................... 64

TABELA 2 - CARACTERIZAÇÃO DOS PARTICIPANTES QUANTO À PROFISSÃO/OCUPAÇÃO, ESCOLARIDADE, CRENÇA RELIGIOSA E ANOS DE RECLUSÃO. BRASÍLIA, 2016 65

TABELA 3 - VULNERABILIDADES INDIVIDUAIS ANTERIORES À INFECÇÃO DO HIV/AIDS. BRASÍLIA, 2016 


\section{LISTA DE SIGLAS}

ADT - Assistência Domiciliar Terapêutica

AIDS - Síndrome da Imunodeficiência Adquirida

ARVS - Antirretrovirais

CEP - Comitê de Ética em Pesquisa

CTA - Centro de Testagem e Aconselhamento

DF - Distrito Federal

DST - Doença Sexualmente Transmissível

EBBS - Exercise Benefit/Barriers Scale

EUA - Estados Unidos da América

FEPECS - Fundação de Ensino e Pesquisa em Ciências da Saúde

GESSP - Gerência de Saúde no Sistema Prisional

HD - Hospital Dia

HDL - High Density Lipoproteins

HIV - Vírus da Imunodeficiência Humana

HPV - Papilomavírus Humano

HSH - Homens que fazem Sexo com Homens

IE - Imunoensaios

INFOPEN - Sistema Integrado de Informações Penitenciárias

INNTR - Inibidores Não Nucleosídeos da Transcriptase Reversa

INTR - Inibidores Nucleosídeos da Transcriptase Reversa

LEP - Lei de Execuções Penais

LDL - Low Density Lipoproteins

LGBT - Lésbicas, Gays, Bissexuais e Transgêneros

MPS - Modelo de Promoção da Saúde

NUS - Núcleo de Saúde

PDF I - Presídio do Distrito Federal I

PDF II - Presídio do Distrito Federal II

PNAISP - Política Nacional de Atenção Integral às Pessoas Privadas de Liberdade no Sistema Prisional

PNSSP - Programa Nacional de Saúde no Sistema Prisional 
PVHA - Pessoas que Vivem com HIV/Aids

SAE - Serviços Ambulatoriais Especializados em HIV/Aids

SESIPE - Subsecretaria do Sistema Penitenciário

SIAPEN - Sistema de Administração Penitenciária

SINAN - Sistema de Informação de Agravos de Notificação

SP - São Paulo

SRA - Síndrome Retroviral Aguda

SUS - Sistema Único de Saúde

TARV - Tratamento Antirretroviral

TB - Tuberculose

TCLE - Termo de Consentimento Livre e Esclarecido

UCE - Unidade de Contexto Elementar

UNAIDS - Programa Conjunto das Nações Unidas sobre HIV/Aids

UDI - Usuários de Drogas Injetáveis

UDM - Unidades Dispensadoras de Antirretrovirais

WHO - World Health Organization 


\section{SUMÁRIO}

APRESENTAÇÃ

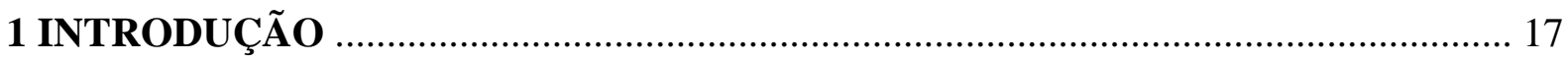

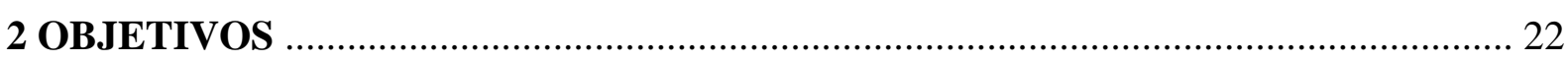

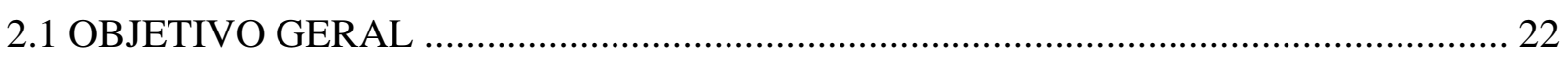

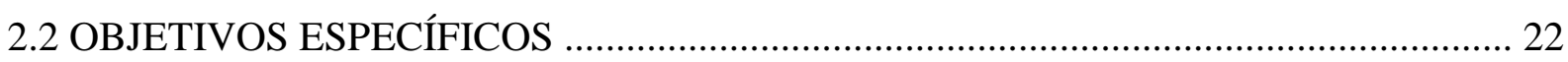

3 CONTEXTUALIZAÇÃO TEMÁTICA E REFERENCIAL TEÓRICO ..................... 23

3.1 DO SUPLÍCIO ÀS PRISÕES: Uma breve história das prisões ....................................... 23

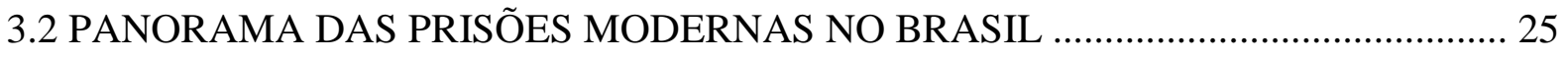

3.3 ASSISTÊNCIA À SAÚDE NAS PENITENCIÁRIAS ................................................. 28

3.3.1 As doenças infectocontagiosas em ambientes prisionais ..................................... 28

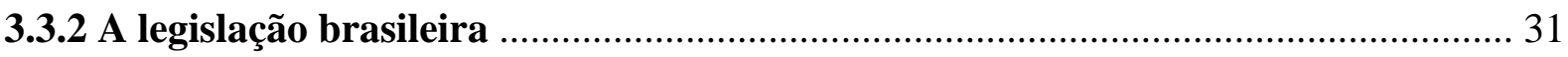

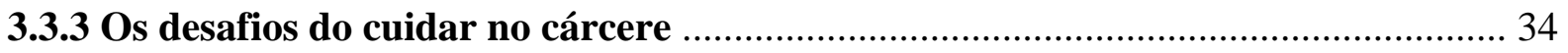

3.3.4 A estrutura penitenciária $X$ assistência à saúde …................................................. 36

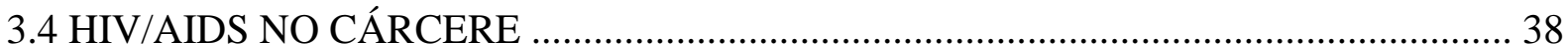

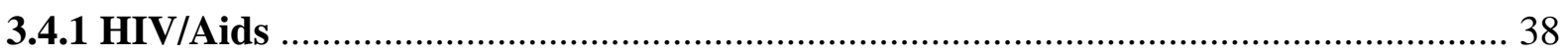

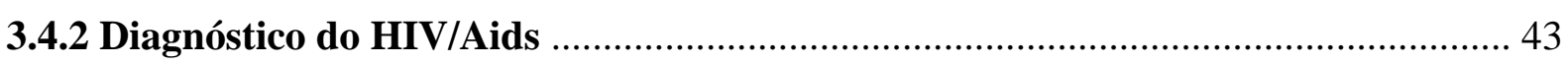

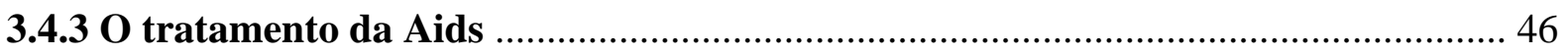

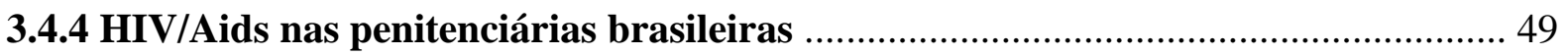

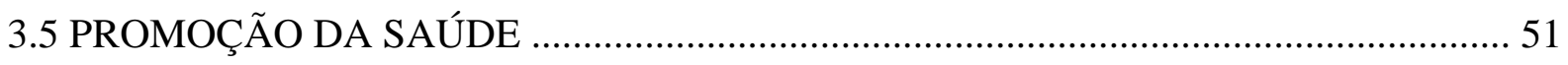

3.5.1 Contextualizando a promoção da saúde ............................................................... 51

3.5.2 O Modelo de Promoção da Saúde, de Nola J. Pender .............................................53

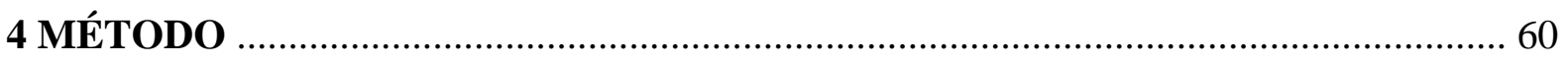

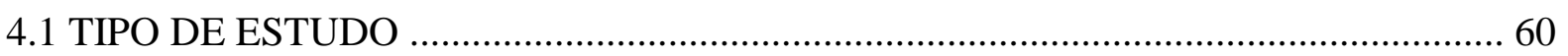

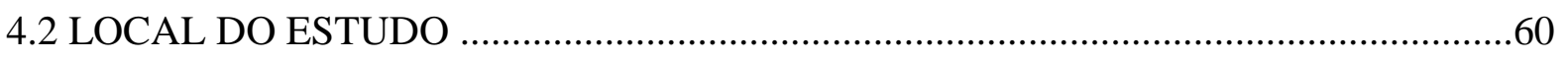

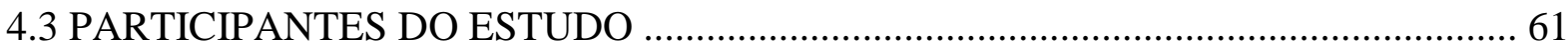

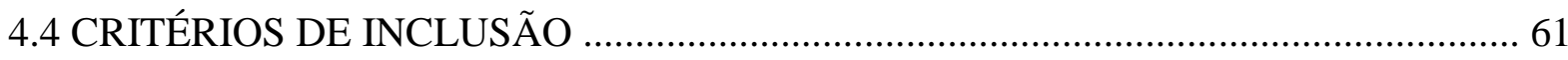

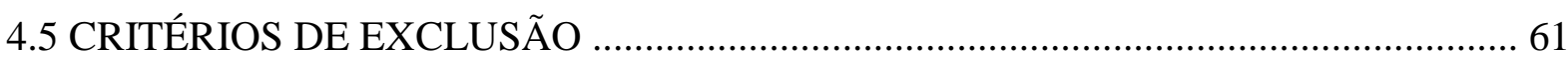

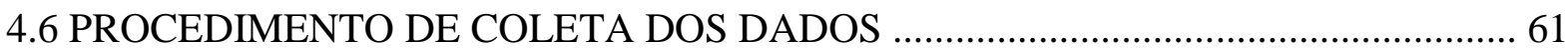

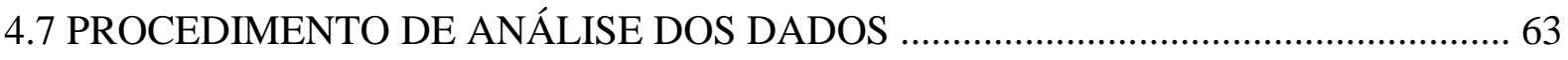

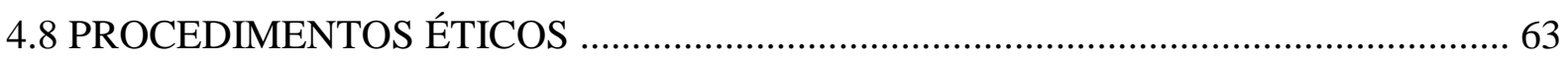


5.2 SOBRE HIV/AIDS E A PROMOÇÃO DA SAÚDE: RELATOS DE PESSOAS PRIVADAS DE LIBERDADE 67

5.2.1 Eixo 1: HIV/Aids no cárcere: vulnerabilidades, diagnóstico, tratamento e as barreiras existentes 68

5.2.1.1 Classe 2: Exame, diagnóstico e tratamento 69

5.2.1.2 Classe 3: Vulnerabilidade, infecção e medicamentos 74

5.2.1.3 Classe 1: Barreiras para a adoção de comportamentos de promoção da saúde 81

5.2.2 Eixo 2: Percepções acerca da promoção da saúde 85

5.2.2.1 Classe 4: Consciência sobre hábitos promotores de saúde 85

5.2.2.2 Classe 5: Hábitos adotados para a promoção da saúde 88

5.3 ADAPTAÇÃO AO MODELO DE PROMOÇÃO DA SAÚDE DE NOLA PENDER ... 92 6 CONSIDERAÇÕES FINAIS 97

REFERÊNCIAS 99

APÊNDICE 1 114

APÊNDICE 2 117

ANEXO 1 119 


\section{APRESENTAÇÃO}

Desde o período da graduação, sempre tive grande interesse pela área da atenção básica em saúde, por ser uma área em que o enfermeiro possui bastante autonomia para estabelecer suas condutas e por acreditar que a promoção e prevenção em saúde são os grandes pilares para se construir uma saúde pública de qualidade.

Durante os estágios, sempre optei por trabalhar com populações carentes e mais vulneráveis, uma vez que percebia maior necessidade e respostas dessa população em minhas ações e serviços.

Logo ao me formar, em 2010, mediante a saturação do mercado de trabalho na área de saúde pública, optei por me especializar em outras áreas de menor interesse pelos enfermeiros em geral, como a "Auditoria em Serviços de Saúde" e "Administração Hospitalar". Mas, concomitantemente, mantive engajamento nos estudos de meu interesse maior, visando alcançar meu grande sonho profissional, ou seja, ingressar no serviço público e assim atuar como enfermeiro da atenção básica, prestando assistência àqueles que mais carecem.

Em junho de 2012, ao ser nomeado na Secretaria de Estado de Saúde do Distrito Federal, esse grande sonho se realizava. No momento da posse, tomei um grande susto, pois fui nomeado enfermeiro da atenção básica, porém com lotação no Complexo Penitenciário do Distrito Federal. Tal notícia me deixou um pouco frustrado, acredito que pelo medo e insegurança de chegar a uma nova cidade, sair da casa dos pais e ainda trabalhar em uma penitenciária, prestando assistência à saúde a uma população totalmente estigmatizada, que necessitaria dos meus serviços, mas, ao mesmo tempo, uma população perigosa e imprevisível, a meu ver capaz de cometer tipos de delitos inimagináveis.

A minha primeira reação foi pedir de exoneração, porém, mediante conversas com os demais colegas e gerentes da área, foi possível fazer um acordo nos seguintes termos: em caso de não adaptação ao serviço, uma nova lotação me seria disponibilizada.

Nos primeiros dias de serviço percebi que ali era um local seguro de se trabalhar e que teria muito a contribuir para a saúde daquela população, e então foi quando decidi ficar.

Desde aquele dia, se passaram quatro anos, e hoje desempenho o meu papel de enfermeiro de forma humanitária, holística, buscando, por meio do cuidado, proporcionar 
maior conforto e qualidade de vida à população privada de liberdade, mesmo com todos os entraves existentes no local.

Atualmente, em meu local de trabalho - a Penitenciária do Distrito Federal I -, coordeno, juntamente com outros profissionais, as ações e processos relacionados às doenças infectocontagiosas, atividade pela qual tenho bastante apreço e gozo de muita autonomia.

Nesse espaço profissional, tenho a oportunidade de criar um vínculo mais estreito com os pacientes acometidos por essas infecções, e observo alguns problemas que portadores de HIV/Aids enfrentam no dia a dia devido ao preconceito que sofrem, não só pelos companheiros de cela, mas também pelo pessoal da segurança pública e por outros profissionais que desempenham alguma ação nestes locais.

Constato, ainda, que a vulnerabilidade às doenças oportunistas e à dificuldade da prática de atividade física em função das normas e condições locais, bem como superlotação, também são fatores que interferem no comportamento de promoção da saúde, prevenção, diagnóstico e adesão ao tratamento do HIV/Aids.

Mediante essas inquietações e por acreditar que a assistência aos portadores de HIV/Aids reclusos nesse Complexo Penitenciário devem ser aperfeiçoadas, desenvolvi este estudo para ampliar o meu olhar e qualificar minha atuação profissional em relação às reais necessidades dessa população.

Acredito que os resultados deste estudo possam nortear profissionais que atuam na área e beneficiar diretamente a população privada de liberdade, portadora de HIV/Aids, bem como desencadear o interesse por novos estudos com essa população, uma vez que a literatura relacionada à sua saúde ainda é muito escassa em nosso país. 


\section{INTRODUÇÃO}

Desde o século passado até os dias atuais, a legislação penal foi se modificando na busca de uma punição mais justa e eficaz. Cada época utilizou suas próprias leis penais pelos mais variados métodos coercitivos; mas isso não significou punir menos, mas, sim, punir melhor, com uma severidade atenuada, justiça e universalidade (FOUCAULT, 2013).

Um grande avanço do direito penal moderno foi o surgimento da individualização das penas, em conformidade com as características singulares de cada criminoso, com a objeção do primário e reincidente, e do crime passional. Nesse momento, a relação castigocorpo se diferencia da época dos suplícios, e relaciona-se à prisão, à reclusão, ao trabalho forçado e à interdição do domicílio, ou seja, a privação dos direitos de liberdade (FOUCAULT, 2013).

$\mathrm{Na}$ perspectiva desse novo advento, o modelo ideal de prisões seria aquele com trabalho obrigatório em oficinas, ocupação constante das pessoas privadas de liberdade, alfabetização, custeio das despesas da prisão por meio do trabalho, com o intuito de transformação do indivíduo, assegurando sua reinserção na sociedade (GOFFMAN, 1974; FOUCAULT, 2013). No entanto, o que podemos ver atualmente é que os estabelecimentos penais são desprovidos desses recursos, inúteis e nocivos à sociedade, pois são caros, mantêm os condenados na ociosidade, multiplicando-lhes os vícios (FOUCAULT, 2013).

Dessa forma, além da superlotação e das péssimas condições de infraestrutura, há uma constante violação dos direitos dos custodiados e um descumprimento das garantias legais previstas nas leis penais. Esses fatos, somados aos mais variados tipos de castigos e punições, afetam diretamente as condutas de comportamento e sua personalidade e dignidade, dificultando, na maioria das vezes, o seu reingresso à sociedade (ASSIS, 2007).

Entretanto, as atuais políticas públicas brasileiras ainda possuem fragilidades relacionadas com a garantia de uma educação qualificada, moradia, lazer, alimentação, saneamento básico e oferta de trabalho, o que dificulta o alcance da promoção da saúde, da qualidade de vida e da ascensão social, gerando, assim, um maior índice da criminalidade e, consequentemente, aumento da população carcerária (NICOLAU et al., 2012).

Segundo dados do Sistema Integrado de Informações Penitenciárias (Infopen), o Brasil possui uma população de 607.731 pessoas privadas de liberdade, caracterizando a 
quarta maior população prisional do mundo, e dispõe atualmente de 1420 estabelecimentos penais estaduais e quatro federais distribuídos pelo país. Destes, 1070 são destinados ao público masculino, 103 ao público feminino, e 242 mistos, que juntos possuem uma capacidade de alojar 376.669 indivíduos, gerando, assim, um défice de 231.062 vagas, com uma taxa de ocupação de 161\% (BRASIL, 2014a).

Essa superpopulação instalada, a precariedade da estrutura física e a lugubridade dos estabelecimentos penais, relacionadas a outros fatores como o tempo de reclusão, o sedentarismo, a alimentação inadequada e desnutrição, a falta de higienização, a marginalização social, o uso de drogas ilícitas e o baixo nível socioeconômico, favorecem a disseminação de doenças infectocontagiosas e de outros agravos, representando, assim, uma ameaça à saúde pública (ASSIS, 2007; GOIS et al., 2012).

Nesse contexto, a disseminação de doenças infectocontagiosas, em especial a infecção pelo HIV/Aids, representam um sério risco à saúde das pessoas privadas de liberdade, de seus contatos (companheiros de celas, familiares e profissionais que atuam no sistema) e para a sociedade, na qual posteriormente irão se reinserir após o livramento (DIUANA et al., 2008).

No mundo todo, os níveis de infecção por HIV entre a população privada de liberdade tendem a ser bem mais altos do que entre a população fora dos ambientes prisionais, e essa situação geralmente é acompanhada e acentuada por uma elevada incidência de hepatite C (HCV), tuberculose, outras Doenças Sexualmente Transmissíveis (DST) e dependência química (UNAIDS, 2007).

Segundo a UNAIDS (2007), internacionalmente, altas taxas de infecção por HIV em ambientes prisionais ocorrem devido ao compartilhamento de material injetável relacionado ao uso de drogas, ou até mesmo utilização compartilhada de lâminas de barbear, e às práticas sexuais sem proteção (principalmente entre homens que fazem sexo com homens).

Estudos realizados em 10 municípios brasileiros, entre 2008 e 2009, estimaram taxas de prevalência de HIV de 5,9\% entre usuários de drogas, de 10,5\% entre homens que fazem sexo com homens e de 4,9\% entre mulheres profissionais do sexo. Dessa forma, evidencia-se que a epidemia do HIV no Brasil possui maior prevalência em populações que vivem em situações de risco e de maior vulnerabilidade (BRASIL, 2013a), características essas bem peculiares à população privada de liberdade, já que nos presídios há uma heterogeneidade 
desta população, o que consequentemente estimula práticas que aumentam o risco de transmissão de doenças infecciosas.

O vírus da imunodeficiência humana - HIV é um retrovírus que tem como uma de suas principais propriedades a infecção de células do sangue e supressão do sistema imunológico. O vírus atinge principalmente os linfócitos T CD4+ do organismo para se multiplicar, os destroem e se disseminam no organismo, ocasionando assim o aumento da carga de vírus circulante e a diminuição do número de linfócitos T CD4+ (PEREIRA et al., 2012).

Ter o vírus HIV não é a mesma coisa que ter a Síndrome da Imunodeficiência Adquirida - Aids; a Aids é a doença causada pelo vírus HIV devido à deterioração progressiva do sistema imune, ocasionando infecções oportunistas, como pneumonia, tuberculose e meningite, que podem levar ao óbito (PEREIRA et al., 2012).

Com o aparecimento dos primeiros casos e a identificação do HIV, a Aids passou a representar um dos grandes problemas de saúde pública no mundo. No Brasil, de acordo com o Boletim Epidemiológico Aids e DST (2015), desde o início de sua epidemia, em 1980, estima-se que haja cerca de 798.366 mil casos de pessoas com Aids, sendo que 615.022 mil foram notificados no Sistema Nacional de Agravos de Notificação (SINAN), e os demais em outros sistemas de notificações; e, destes 519.183 (65,0\%) são do sexo masculino e 278.960 $(35,0 \%)$ do sexo feminino, demonstrando assim crescimento significativo de taxas de detecção de Aids em homens nos últimos dez anos (BRASIL, 2015a).

Diante da situação epidemiológica do HIV/Aids no Brasil e no mundo, nenhuma doença exigiu tanto envolvimento de organizações governamentais e não governamentais, mobilizando a sociedade sob diversos aspectos. Várias conquistas foram obtidas, em termos científicos, tecnológicos e humanísticos (GIR; VAICHUNOLIS; OLIVEIRA, 2005). Destacam-se, dentre outras ações, a descoberta e distribuição universal de medicamentos antirretrovirais (ARVS), o que possibilitou transformar a Aids em uma doença de característica crônica (COLOMBRINI; LOPES; FIGUEIREDO, 2006).

Os benefícios do tratamento com antirretrovirais são satisfatórios, uma vez que diminui consideravelmente a carga viral ou até mesmo a torna indetectável, possibilitando, assim, maior sobrevida, melhor qualidade de vida, diminuição das doenças oportunistas e, consequentemente, redução das frequências de internações hospitalares. No entanto, para um 
tratamento eficaz, é necessária uma rígida adesão por parte da pessoa que vive com HIV/Aids (PVHA) (GIR; VAICHUNOLIS; OLIVEIRA, 2005).

Vários estudos relataram a dificuldade de adesão ao tratamento do HIV/Aids, devido, entre outros fatores, aos efeitos colaterais, a fatores psicológicos, à quantidade de medicamentos e sua correta posologia (ALMEIDA et al., 2011; COLOMBRINI, LOPES, FIGUEIREDO, 2006; GIR, VAICHUNOLIS, OLIVEIRA, 2005). Segundo Almeida et al. (2011), para minimizar o abandono ao tratamento, faz-se necessário considerar a rotina diária do paciente, seus hábitos de vida, conhecer o seu perfil biopsicossocial, e fornecer orientações específicas sobre cada medicamento.

Em estudo realizado com pessoas que vivem com HIV/Aids - PVHA, Meirelles et al. (2010) puderam perceber que as dificuldades psicológicas e sociais, que se expressam por meio do medo, do preconceito, da discriminação e da falta de informação, são fatores que mais influenciam no viver com essa condição de saúde, interferindo diretamente na qualidade de vida desses pacientes.

Para que se possa viver melhor com HIV/Aids, é necessário almejar uma melhor qualidade de vida por meio da adoção de comportamentos de promoção da saúde, tais como a prática de atividade física regular, alimentação saudável, sono e repouso satisfatórios, aliados ao uso correto dos antirretrovirais e à busca de superar os impactos e limitações provenientes da doença, que atingem o aspecto físico, social e pessoal (ALMEIDA et al., 2011; MEIRELLES et al., 2010).

A cronicidade da Aids prevê o seguimento dos pacientes a longo prazo; uma equipe de saúde multiprofissional, humanizada e treinada que se dispõe a estruturar os serviços para atender as novas demandas que possam surgir, buscar sempre acompanhar e avaliar seus pacientes intervindo na prevenção e promoção da saúde, orientando e incentivando a adoção de hábitos saudáveis que, consequentemente, poderão reduzir os riscos do agravamento ou adoecimento, potencializando assim uma melhor qualidade de vida (MEIRELLES et al., 2010).

Dentro desse contexto, percebe-se então a crescente participação dos enfermeiros nas ações de promoção da saúde, e dentre os modelos e teorias de enfermagem que visam à integralização do cuidado, em se tratando de promoção da saúde, destaca-se o Modelo de Promoção da Saúde, de Nola Pender (1982), que surge como uma proposta para integrar as ciências do comportamento às teorias de enfermagem, fundamentando a concepção de 
promoção da saúde em ações voltadas para o desenvolvimento de alternativas para se estimular ou intensificar adoção de comportamentos saudáveis (GUEDES et al., 2009; VICTOR, LOPES, XIMENES, 2005).

Diante da concepção de que as ações de promoção da saúde trazem benefícios significativos na qualidade de vida, bem como possibilita acompanhar o cuidado em saúde, é imprescindível investigarmos as condutas de promoção da saúde realizadas pelas PVHA nesses locais, e a partir da identificação, desenvolver políticas de intervenções que incentivem a adesão de tais práticas (MEIRELLES et al., 2010).

Porém, dentro do contexto prisional, ao contrário do que se imagina, tendo em vista uma clientela delimitada intramuros aparentemente sob controle, são inúmeras as dificuldades para o desenvolvimento de ações de saúde, principalmente relacionados com a sua prevenção e promoção. Nesses ambientes, devido à periculosidade do local, a circulação das pessoas privadas de liberdade e dos profissionais de saúde é restrita, e isso faz com que muitas vezes os profissionais de segurança assumam a função de julgar a necessidade de atendimento à saúde, facilitando ou dificultando o processo (DIUANA et al., 2008).

Devido à carência de estudos desenvolvidos relacionados ao tema em ambientes prisionais, é de extrema relevância e especificidade identificarmos fatores facilitadores e barreiras existentes dentro do universo prisional para se adotar comportamentos de promoção da saúde, visando o planejamento de intervenções de enfermagem com o intuito de mitigar os riscos existentes, possibilitando, assim, maior qualidade de vida a estes pacientes mesmo com todas as limitações causadas pela doença e pelo ambiente em que se encontram.

Assim, o estudo em questão visa responder à seguinte pergunta de pesquisa: As pessoas privadas de liberdade portadoras de HIV/Aids, que cumprem sua sentença no Complexo Penitenciário do Distrito Federal - Papuda, adotam comportamentos de promoção da saúde? 


\section{OBJETIVOS}

\subsection{OBJETIVO GERAL}

Investigar comportamentos de promoção da saúde das pessoas privadas de liberdade portadoras de HIV/Aids no Complexo Penitenciário do Distrito Federal - Papuda à luz do Modelo de Promoção da Saúde de Nola Pender.

\subsection{OBJETIVOS ESPECÍFICOS}

- Identificar as características sociodemográficas e de saúde dos portadores de HIV/Aids do Complexo Penitenciário da Papuda;

- Descrever a vivência das pessoas privadas de liberdade do Complexo Penitenciário da Papuda, considerando sua condição de portadores de HIV/Aids;

- Apreender as experiências de promoção da saúde dos portadores de HIV/Aids em privação de liberdade;

- Identificar práticas comportamentais e os fatores que facilitam ou dificultam a adoção destas práticas;

- Propor adaptação do Modelo de Promoção da Saúde de Nola Pender para as pessoas privadas de liberdade portadoras de HIV/Aids. 


\section{CONTEXTUALIZAÇÃO DA TEMÁTICA E REFERENCIAL TEÓRICO}

\subsection{DO SUPLÍCIO ÀS PRISÕES: Uma breve história das prisões}

Durante o século XVII e metade do século XVIII, a forma de punição para as pessoas que cometiam crimes ou delitos se dava por meio do suplício, que se baseava em um ritual marcante, ficando registrado no corpo ou na memória da vítima; ao mesmo tempo, pelo lado da justiça que se impunha, o suplício devia ser ostentoso e constatado por todos (FOUCAULT, 2013).

O termo suplício é definido pelo dicionário da língua portuguesa Houaiss como uma grave punição corporal ordenada por sentença; ou, ainda, sofrimento intenso provocado em um ser humano por técnicas especiais que podem envolver aparelhos especialmente desenvolvidos para isso, com o fim de obter revelações ou confissão de crimes.

A finalidade do suplício era punir e intimidar a sociedade para assim impedir o futuro descumprimento das leis, sendo a reprodução do crime na execução do culpado quase uma encenação teatral, um ritual político que não restabelecia a justiça, e sim reafirmava o poder do Estado (FOUCAULT, 2013).

\footnotetext{
“... uns podem ser condenados à forca, outros a ter a mão ou língua cortada ou furada e ser enforcados em seguida; outros, por crimes mais graves, a ser arrebentados vivos e expirar na roda depois de ter os membros arrebentados; outros a ser arrebentados até a morte natural, outros a ser estrangulados e em seguida arrebentados, outros a ser queimados vivos, outros a ser queimados depois de estrangulados; outros a ter a língua cortada ou furada e em seguida queimados vivos; outros a ser puxados por quatro cavalos, outros a ter a cabeça cortada, outros, enfim, a ter a cabeça quebrada" (FOUCAULT, 2013, pag. 34).
}

Não era incomum que nessas demonstrações de suplícios a população se revoltasse, por entender que a era execução injusta, caluniando os juízes e fazendo tumulto contra a sentença. Em algumas situações, o condenado poderia se tornar herói pela grandiosidade de seus crimes cometidos, e, às vezes, pela afirmação de seu arrependimento tardio (FOUCAULT, 2013).

O protesto contra os suplícios ocorreu na segunda metade do século XVIII, quando o Iluminismo tornou a prática dos suplícios inaceitável, pois revelava tirania, excesso, a sede de vingança e o cruel prazer de punir. Dessa forma, não havia mais heróis populares e nem 
grandes execuções; a pena era destinada a prevenir delitos e não simplesmente castigar (FOUCAULT, 2013; NUCCI, 2011).

O castigo passou de uma arte das sensações insuportáveis a uma privação dos direitos de liberdade, definindo uma moral moderna do ato de punir; porém, mesmo assim, sempre existiram certos complementos punitivos referentes ao corpo, como a redução alimentar, privação sexual e outros (FOUCAULT, 2013).

Inicialmente, as prisões, eram estabelecimentos para se guardarem os réus, preservando-os fisicamente, até serem julgados. As prisões com o intuito de um lugar para o cumprimento da pena foi realmente implementado em 1681, por meio da fundação da colônia da Pensilvânia, e, a partir daí, vários sistemas penitenciários foram criados e aperfeiçoados, na busca de proteger a sociedade e ressocializar o criminoso (NUCCI, 2011).

Goffman (1974) refere que as prisões podem ser classificadas como uma instituição total, definida como um local de residência e trabalho, onde um grande número de pessoas com situações semelhantes ficam separadas da sociedade por um período determinado, levando uma vida fechada e formalmente controlada.

Essas instituições possuem uma organização hierárquica, em que existe um grande grupo controlado, denominado e internado, que tende a se sentir, na maioria das situações, inferior e fraco; e uma pequena equipe dirigente, responsável pela supervisão e que tende a sentir-se superior e correta (GOFFMAN, 1974).

As prisões marcaram a história da justiça penal, quando se iniciaram a transição de um local árduo, detestável, de penas duras, para um local mais humanizado, passando a ser uma forma mais imediata e civilizada de se cumprir a pena imposta; onde cada um deve ser tratado de acordo com o crime, cumprindo assim sua respectiva pena (FOUCAULT, 2013).

Essas novas medidas de segurança que acompanham a pena, tendo como princípios o isolamento do mundo exterior, o trabalho e disciplina exacerbados, têm a finalidade de controlar o indivíduo, neutralizar sua periculosidade, modificar suas disposições criminosas, e, somente após tais modificações, é que o mesmo estaria apto para se reintegrar à sociedade (DASSI, 2006; FOUCAULT, 2013). 


\subsection{PANORAMA DAS PRISÕES MODERNAS NO BRASIL}

No Brasil, o cumprimento das penas privativas de liberdade é disciplinado pela Constituição Federal, pelo Código Penal e regulamentado pela Lei 7210/84, a Lei de Execuções Penais (LEP), que tem como objetivo a ressocialização das pessoas privadas de liberdade (BRASIL, 1984).

O capítulo II, seção I, artigos 10 e 11 da LEP, ressalta que a assistência ao preso e ao internado é dever do Estado, sendo garantida ao egresso assistência material, à saúde, jurídica, educacional, social e religiosa. O objetivo da oferta dessa assistência é prevenir o crime e orientar o retorno do convívio na sociedade (BRASIL, 1984).

O estatuto executivo-penal brasileiro é considerado um dos mais avançados e democráticos existentes, por se basear na premissa de que a execução da pena privativa de liberdade deve ter por base o princípio da humanidade, sendo intolerável qualquer tipo de punição desnecessária, cruel ou degradante, ou que viole os direitos previstos (ASSIS, 2007).

Entretanto, observa-se uma omissão do Estado em relação a essas premissas, nas penitenciárias do país, demonstrando a ineficiência destas, pois as prisões não são capazes de diminuir as taxas de criminalidade e de criminosos, pelo contrário, elas tendem a aumentarem ou se modificarem, devido à exclusão, superlotação, infraestrutura precária, ociosidade, a convivência e o abuso do poder (ASSIS, 2007; MACHADO, 2009).

No Brasil, criou-se o Sistema Integrado de Informações Penitenciárias (INFOPEN), atualizado pelos gestores dos estabelecimentos penais, que sintetiza as informações sobre as unidades e a população prisional. O objetivo desse relatório anual é aprimorar o diagnóstico do sistema prisional e, assim, possibilitar a elaboração de políticas públicas cada vez mais adequadas à realidade prisional. Apesar de sua importância, ressaltam-se obstáculos na coleta dos dados, sendo um deles a não adesão de todas as unidades prisionais do país (BRASIL, 2014a).

Segundo dados do Infopen (2014), o Brasil possui a quarta maior população prisional (607.731 mil), sendo liderado pelos Estados Unidos, China e Rússia, e a quinta maior taxa de ocupação dos estabelecimentos prisionais (161\%). Um dado preocupante, em relação ao período 2008 - 2013, demonstra que, entre os quatro países que possuem a maior população prisional do mundo, a taxa de aprisionamento brasileira apresentou tendência contrária aos outros três, com aumento de $33 \%$ da população prisional, ao passo que os demais reduziram 
significativamente, tendo os Estados Unidos uma redução de 8\%, a China de 9\%, e a Rússia de $24 \%$ (BRASIL, 2014a).

No Brasil, o número de pessoas privadas de liberdade nas Unidades Federativas é bastante discrepante, tendo o estado de São Paulo 219.073 pessoas privadas de liberdade, o que representa $36 \%$ da população prisional do país. Em relação à taxa de aprisionamento (n. ${ }^{\circ}$ pessoas privadas de liberdade/100 mil habitantes), o estado de São Paulo se posiciona em segundo lugar da lista, com 497,4 pessoas privadas de liberdade para cem mil habitantes, seguido pelo Distrito Federal (DF) com uma taxa de 496,8 pessoas privadas de liberdade para cem mil habitantes (BRASIL, 2014a).

De acordo com dados de março de 2016, da Subsecretaria do Sistema Penitenciário do DF (SESIPE-DF), o Distrito Federal disponibiliza 7.411 vagas em todas as suas penitenciárias, abrigando 14.533 pessoas privadas de liberdade. No Complexo Penitenciário da Papuda, formado por quatro unidades prisionais destinadas exclusivamente ao público masculino, concentra-se o maior número das vagas, correspondendo a 5.053, porém abriga 12.186 pessoas privadas de liberdade, o que representa aproximadamente $140 \%$ a mais de sua capacidade, gerando, assim, um défice de 7.133 vagas (DISTRITO FEDERAL, 2016a).

Quanto à natureza da prisão e ao tipo de regime, constata-se que cerca de $41 \%$ das pessoas privadas de liberdade não possuem condenação, a mesma proporção de pessoas em regime fechado. Apenas 3\% das pessoas privadas de liberdade estão em regime aberto e $15 \%$ em semiaberto. Esses dados evidenciam um dos motivos da superlotação dos presídios brasileiros, pois, apesar de o número de vagas ter quase triplicado nos últimos anos, chegando a 375.892 vagas, o défice de vagas mais do que dobrou, chegando a uma taxa de ocupação prisional brasileira de $161 \%$. Ou seja, no Brasil, em um espaço concebido para custodiar apenas dez indivíduos, há, em média, 16 pessoas encarceradas (BRASIL, 2014a).

Dentre todos os estabelecimentos penais no Brasil, a maior parte, três quartos, é voltada ao público masculino, sendo que há menos unidades prisionais femininas (7\%) do que estabelecimentos mistos (17\%). Em relação à disponibilidade de vagas exclusivas a grupos específicos, apenas 9\% das unidades dispõem de celas específicas para estrangeiros e para indígenas, e $15 \%$ dos estabelecimentos têm celas específicas para idosos e para pessoas lésbicas, gays, bissexuais e transgêneros - LGBT. Em apenas $6 \%$ das unidades analisadas registrou-se a existência de módulos, alas ou celas com acessibilidade para portadores de deficiência física, conforme a legislação em vigor (BRASIL, 2014a). 
Na obra "Estação Carandiru”, Dráuzio Varella (2009) descreve de maneira fidedigna a realidade do sistema prisional brasileiro com base em suas vivências e experiências adquiridas ao longo dos dez anos como médico na Casa de Detenção de São Paulo, o maior presídio do Brasil. Apesar de seu objetivo não ter sido denunciar um sistema penal antiquado, apontar soluções para a criminalidade ou defender os direitos humanos, Dráuzio revelou como um código penal não escrito organizava o comportamento da população carcerária para se adaptar ao ambiente e se proteger. Não importava a pena a que tinham sido condenados, todos ali se encontravam em situações semelhantes e seguiam a um rígido código penal, criado pela própria massa carcerária, em que desrespeitá-lo poderia equivaler a penas severas e brutais, inclusive a morte.

Segundo Machado (2009), o sistema prisional brasileiro está entrando em falência, e isso representa um dos mais graves problemas sociais da atualidade, pois as penitenciárias no país vêm se tornando cruéis masmorras, com uma superlotação instalada onde se encontram pessoas privadas de liberdade em regime provisório misturados com condenados, empilhados num espaço físico mínimo, com péssimas condições de infraestrutura, higiene e alimentação, ocasionando, assim a propagação de doenças e despertando o sentimento de revolta e injustiça.

Assis (2007) revela que, apesar da ausência de números oficiais, calcula-se que, no Brasil, em média, 90\% dos ex-detentos que retornam à sociedade voltam a praticar crimes, e, consequentemente, acabam retornando à prisão. Essa situação é um reflexo das péssimas condições em que os condenados são submetidos dentro ambiente prisional, num processo que não oferece quaisquer preparações para a ressocialização.

Além do descaso estatal em relação às penitenciárias, percebe-se também que uma grande parcela da sociedade, amedrontada pelo elevado índice de criminalidade, não se sensibiliza com a situação desumana em que se encontram as pessoas privadas de liberdade, prevalecendo na sociedade um pensamento de conformidade e tolerância absoluta em relação à violação dos direitos dos custodiados, mostrando-se indiferente quanto ao caos do sistema carcerário brasileiro (MACHADO, 2009).

Portanto, enquanto persistir essa negligência de ambos os lados, tratando as prisões como um depósito de lixo humano e de seres imprestáveis para o convívio em sociedade, não apenas a situação carcerária, mas o problema da segurança pública e da criminalidade como um todo, tendem apenas a agravar-se (ASSIS, 2007). 


\subsection{ASSISTÊNCIA À SAÚDE NAS PENITENCIÁRIAS}

No Brasil, as pessoas privadas de liberdade estão sob a tutela do Estado, e esse fato não os tira os direitos fundamentais relacionados com a integridade física, moral e também com a dignidade humana. A Lei de Execução Penal, n. ${ }^{\text {o } 7.210, ~ d e ~} 11$ de julho de 1984, prevê, no inciso VII do art. 41, o direito à saúde por parte do preso como uma obrigação do Estado, sem possibilidades de suspensão, mantendo o direito de gozar dos mais elevados padrões de assistência à saúde (BRASIL, 1984).

De uma maneira perversa, o sistema de justiça criminal presta um serviço à saúde pública, reunindo membros da sociedade com elevado risco para doenças (SPAULDING et al., 2011), e, frequentemente, estes, durante o período de liberdade, não buscam os serviços de saúde (COLE et al., 2014). Para alguns detentos, durante a reclusão, nota-se a primeira oportunidade de receber um atendimento por profissionais de saúde (ARRIOLA et al., 2001).

As peculiaridades sociais e psicológicas relacionadas à luta pelo poder, à organização e funcionamento de instituições prisionais, decorrentes da priorização da segurança em detrimento da saúde e ao preconceito existentes em aceitar a saúde como um direito das pessoas presas, somadas às necessidades de segurança, acabam induzindo ações de saúde eminentemente prescritivas (DIUANA et al., 2008; SOUZA et al., 2012).

Os Estados Unidos da América - EUA têm o maior número de prisioneiros per capita, sendo em média 756 por 100.000 habitantes, em comparação com uma média de 145 por 100.000 habitantes em todo o mundo. As condições de saúde dessa população são, geralmente, bastante precárias, podendo deduzir que a disparidade do estado de saúde entre os prisioneiros e a população em geral está atribuída a fatores comportamentais de risco e condições socioeconômicas precárias, com destaque na alta taxa de uso de drogas injetáveis, consumo de álcool e tabaco, comportamentos esses que aumentam o risco de doenças infecciosas, cardiovasculares, alguns tipos de câncer e também de doenças mentais, que por sua vez aumentam o risco da criminalidade e reincidência (FAZEL; BAILLARGEON, 2011).

\subsubsection{As doenças infectocontagiosas em ambientes prisionais}

Várias são as complicações de saúde que acometem a população privada de liberdade, sendo que as doenças de maior prevalência estão relacionadas ao trato respiratório 
(tuberculose, pneumonias), às doenças sexualmente transmissíveis (DSTs, Hepatites e HIV/Aids) e às infecções dermatológicas. Desse modo, pode-se considerar que, devido às situações enfrentadas dentro do ambiente prisional, há uma dupla penalização do condenado, estando uma relacionada à sua perda da liberdade e, a outra, ao lastimável estado de saúde que ele adquire durante a sua permanência no cárcere, fazendo com que os custodiados não saiam sem ser acometidos por uma doença ou com sua resistência física e de saúde fragilizadas (ASSIS, 2007).

Estudos relacionados com a saúde das pessoas privadas de liberdade são, muitas vezes, oriundos de países de alta renda, e revelam apenas dados relacionados com as doenças infectocontagiosas, desconhecendo, assim, as situações dos outros agravos que acometem essa população de países em desenvolvimento (FAZEL; BAILLARGEON, 2011).

Em relação às doenças infecciosas, o rastreamento deveria ser parte integral do papel do sistema prisional, devido à facilidade de transmissão e à alta prevalência de tais doenças. Instituir o tratamento pode ser benéfico não apenas para o indivíduo, mas também para a comunidade em geral (ARRIOLA et al., 2001).

Uma ação benéfica para a população carcerária e também para a saúde pública no geral seria a oferta de testagem rápida para DSTs, com estabelecimento do tratamento imediato (PARECE et al., 1999), prevenindo a transmissão subsequente, podendo reduzir taxas de infecção na comunidade (BARRY et al., 2009; SPAULDING et al., 2009), pois o seguimento após a liberdade é usualmente difícil e improdutivo, porque essa população frequentemente utiliza informações pessoais falsas, não possui endereço permanente e raramente procuram os serviços de saúde (PARECE et al., 1999).

Uma análise da prevalência de HIV em prisões de países de média e baixa renda, dos 75 que informaram os dados, a prevalência da doença era superior a 10\% em 20 deles, sendo essas informações substanciais, pois vários países não notificaram nenhum caso de HIV (DOLAN et al. 2007).

Os dados de prevalência do HIV em populações carcerárias de países de alta renda também variam bastante, sendo que, desde 1991, quando o governo dos EUA começou a coletar dados sobre a infecção pelo HIV em pessoas reclusas, a prevalência variou de $2 \%$ a 5\% em 1992 e de 1\% a 5\% entre os anos de 2007 e 2008; já em outros países de alta renda, como a Itália, esse dado varia de 7\% a 5\%, sendo 0\% na Dinamarca (CHRISTENSEN et al., 2000). 
Infecção pelo vírus da hepatite B é comum em populações carcerárias, com grandes variações entre os países, e até dentro dos mesmos, devido às situações sociodemográficas e culturais de cada região (HARZKE et al., 2009). Estima-se que a prevalência da infecção crônica pelo vírus da hepatite B em prisioneiros norte-americanos seja de 1,0\% a 3,7; em contrapartida, a taxa de infecção crônica na população em geral é cerca de $0,4 \%$ a $0,5 \%$ (WEINBAUM; SABIN; SANTIBANEZ, 2005).

Outro grave problema de saúde pública é o grande número de prisioneiros infectados pelo vírus da hepatite $\mathrm{C}$ em todo o mundo. Uma revisão de 30 estudos realizados em 14 países, sobre a prevalência do vírus da hepatite $\mathrm{C}$ nas populações prisionais, constatou que cerca de $30 \%$ a $40 \%$ dos prisioneiros possuíam anticorpos contra o vírus da hepatite C (VESCIO et al. 2008), podendo esse dado estar diretamente relacionado com a utilização de drogas injetáveis. Já nos EUA, as estimativas de prevalência do vírus da hepatite C nas unidades prisionais variam de $23 \%$ a 34\%, a depender do Estado (FOX et al., 2005; MACALINO et al., 2004).

A tuberculose possui uma prevalência maior em pessoas privadas de liberdade do que na população em geral, principalmente em países de baixa renda, sendo 17.808 casos por 100 mil prisioneiros no Cazaquistão, 2065 casos por 100 mil prisioneiros em São Paulo Brasil, e 3199 casos por 100 mil prisioneiros em São Petersburgo, na Rússia (FAZEL; BAILLARGEN, 2011). Porém, há vários estudos que evidenciam altas taxas de infecções por tuberculose na Europa e nos EUA, sendo que a taxa média de notificação em 13 países da Europa Ocidental, em 2002, foi de 90 casos por 100 mil prisioneiros (AERTS et al., 2006).

A prevalência estimada de tuberculose entre os anos de 1993 e 2003, nos EUA, foi de 29,4 casos por 100 mil prisioneiros nas prisões federais, e de 24,2 casos por 100 mil prisioneiros nas prisões estaduais; sendo que na população em geral essa prevalência era de 6,7 casos por 100 mil habitantes (MACNEIL; LOBATO; MOORE, 2005).

Altas taxas de prevalência por tuberculose justificam-se devido aos elevados fatores de risco que essa população está exposta, incluindo a infecção pelo HIV, o uso de drogas injetáveis, o baixo nível socioeconômico, a desnutrição, a falta de moradia e a dificuldade de acesso aos serviços de saúde. Somado a isso, após o cárcere, fatores como má ventilação e superlotação contribuem para a transmissão e disseminação da doença (BONE et al., 2000; MACNEIL; LOBATO; MOORE, 2005). 
No âmbito nacional, evidencia-se maior prevalência de estudos relacionados com a tuberculose (TB) em presídios, porém, mesmo com esse avanço, a magnitude do problema da TB em ambientes prisionais é pouco conhecida devido à baixa implantação de programas específicos de vigilância epidemiológica e de controle de TB na população carcerária (BRASIL, 2011; SANCHEZ et al., 2007).

Em 2007, em uma primeira avaliação nacional, a população prisional, que representava apenas $0,2 \%$ da população do país, contribuía com $5 \%$ dos casos notificados em 2008 no Sistema de Informação de Agravos de Notificação (SINAN), despertando, dessa forma, para a necessidade de pesquisas na área devido à probabilidade de surtos e maiores consequências à população (BRASIL, 2011).

Segundo o levantamento do Infopen (2014), relacionado aos agravos de saúde que acometem a população privada de liberdade no Brasil, apenas 49\% dos estabelecimentos prisionais responderam a esse quesito, abrangendo uma população de 235.628 pessoas privadas de liberdade. Dentre os agravos, pôde-se verificar que houve uma prevalência, a cada mil pessoas presas, de 12,2 pessoas infectadas por HIV; 10,4 com infecção por sífilis; 5,1 portadoras do vírus da hepatite; 9,4 infectadas por tuberculose; e 2,5 acometidas por outros agravos (BRASIL, 2014a).

No período de março de 2016, em todas as Penitenciárias do Distrito Federal, havia uma população carcerária de 14.533 pessoas privadas de liberdade com acesso aos serviços de saúde (DISTRITO FEDERAL, 2016a), e de acordo com a Gerência de Saúde no Sistema Prisional (GESSP), durante o mesmo período, foram registrados nessa população 97 casos de HIV/Aids $(0,7 \%), 10$ de hepatite B $(0,1 \%), 33$ de hepatite C (0,2\%), 221 de outras DSTs $(1,5 \%), 16$ de tuberculose $(0,1 \%)$ e dois de hanseníase $(0,01 \%)$. Outros agravos, como hipertensão arterial, diabetes e asma, somaram 884 casos $(5,8 \%)$ (DISTRITO FEDERAL, 2016b).

De acordo com consensos internacionais e nacionais, avaliações de saúde em todas as pessoas privadas de liberdade no ato da admissão nas prisões devem ser rotineiras; entretanto, estas não são implementadas na maioria das prisões de países em desenvolvimento, incluindo o Brasil (KAVASERY et al., 2009; SANCHEZ et al., 2009).

\subsubsection{A legislação brasileira}


Diante da grave situação de confinamento das pessoas privadas de liberdade, fez-se necessária a criação do Plano Nacional de Saúde no Sistema Penitenciário (PNSSP), instituído pela Portaria Interministerial n. ${ }^{\circ} 1777$, de 09 de setembro de 2003, que garante o acesso a ações e serviços de atenção básica em saúde in loco a essa população, baseada nos princípios do Sistema Único de Saúde (SUS) - universalidade, equidade e integralidade, e na promoção, prevenção, proteção, tratamento e reabilitação em saúde -, podendo referenciar, se necessário, à atenção especializada ambulatorial e hospitalar (BRASIL, 2004).

Embora tenha se elaborado um plano nacional, a implantação de um programa de assistência ao custodiado enfrenta inúmeros entraves, estando eles relacionados à grande variabilidade de agravos à saúde de acordo com as características da população carcerária; a superpopulação instalada; as características das equipes de saúde no que se refere à disponibilidade e capacitação; a falta de infraestrutura adequada para os atendimentos; os impasses existentes entre saúde e segurança; e a relação da unidade prisional com a hierarquia do SUS (FERNANDES et al., 2014).

Em busca de resolver esses entraves, recentemente, instituíram a Política Nacional de Atenção Integral à Saúde das Pessoas Privadas de Liberdade no Sistema Prisional (PNAISP) no âmbito do SUS, em substituição ao PNSSP. A PNAISP é regulamentada pela Portaria Interministerial n. ${ }^{\circ} 1$, de 02 de janeiro de 2014, e, dentre várias especificações, garante a essa população serviços de saúde de forma integral por meio da permanência das equipes de saúde nos estabelecimentos prisionais (BRASIL, 2014b).

Segundo a Portaria n..$^{\circ} 482$, de $1 .^{\circ}$ de abril de 2014 , que institui as normas para a operacionalização do PNAISP no âmbito do Sistema Único de Saúde (SUS), para unidades com até 100 custodiados, é preconizado uma equipe de atenção básica prisional tipo I ou uma equipe de atenção básica prisional tipo I com saúde mental, com carga horária de 6 horas semanais por profissional que a compõe; para unidades entre 101 e 500 custodiados, preconiza-se uma equipe de atenção básica prisional tipo II ou uma equipe de atenção básica prisional tipo II com saúde mental, com carga horária de 20 horas semanais para cada profissional; e para unidades que mantêm entre 501 até 1200 custodiados, a equipe de atenção básica prisional tipo III, já contemplados os profissionais de saúde mental, com carga horária de 30 horas semanais a serem cumpridas individualmente (BRASIL, 2014c).

Dentre os profissionais que compõem essas equipes, eles variam entre médico clínico, enfermeiro, cirurgião-dentista, assistente social, psicólogo, terapeuta ocupacional, 
fisioterapeuta, farmacêutico, nutricionista, médico psiquiatra ou com experiência em saúde mental, técnico/auxiliar de enfermagem e técnico/auxiliar de higiene bucal (BRASIL, 2014c).

Observa-se que, mesmo com a regulamentação de equipes de saúde nos estabelecimentos prisionais, o quantitativo de profissionais de saúde não se mostrou compatível com a recomendação da portaria governamental, contendo equipes incompletas e com uma disparidade acentuada entre as categorias profissionais, com menor quantitativo de profissionais de nível superior - como médicos, enfermeiros e cirurgiões-dentistas (CARTAXO et al., 2013; FERNANDES et al., 2014). Além do défice de profissionais nas equipes, nota-se que muitos não cumpriam a carga horária contratual e os atendimentos baseavam-se então no tratamento das enfermidades e não na prevenção e promoção da saúde (NICOLAU et al., 2012).

Segundo dados relacionados com a saúde nas penitenciárias brasileiras, constata-se que 796 (63\%) unidades prisionais não possuem módulo de saúde, e 462 (37\%) oferecem este serviço no local. Percebe-se ainda que essa porcentagem é maior entre os presídios femininos (52\%), em relação aos presídios mistos (42\%) e masculinos (34\%) (BRASIL, 2014a).

Apesar de apenas $37 \%$ dos estabelecimentos possuírem módulo de saúde, estes alojam 63\% da população privada de liberdade (BRASIL, 2014a).

Outra diferença relevante em relação ao atendimento de saúde é o tipo de regime das penitenciárias, em que os estabelecimentos que mantêm pessoas privadas de liberdade em regime aberto ou de limitações de final de semana são os que menos dispõem dessas equipes - apenas $17 \%$, o que pode ser justificado pelo fato de que o detento possui capacidade de procurar por atendimento na rede comum (BRASIL, 2014a).

Já em relação aos presídios onde não há possibilidades de se buscar atendimentos de saúde por meios próprios, nota-se apenas que um em cada quatro estabelecimentos (25\%) destinados ao recolhimento de detentos provisórios possui equipe de saúde, situação esta menos agravante nos presídios destinados ao cumprimento de pena em regime fechado, onde dois em cada três estabelecimentos (66\%) possuem módulo de saúde (BRASIL, 2014a).

A unidade federativa do Brasil que apresenta a melhor situação em relação aos estabelecimentos que possuem módulo de saúde é o Distrito Federal, onde todas as unidades contam com equipes de saúde completas, tendo a presença do profissional médico em sua composição (BRASIL, 2014a). 
Mediante aos dados apresentados, mesmo com a legislação vigente relacionada à saúde no sistema penitenciário, na realidade, observa-se que o direito à saúde está sendo descumprido devido à assistência deficitária e precária, às limitações existentes em prol da segurança e, em determinadas situações, há falta dessa assistência, tornando-se um problema de saúde pública (GALVÃO; DAVIM, 2013).

Isso se deve a vários motivos, dentre eles o quantitativo reduzido de profissionais da saúde, os problemas de infraestrutura, a falta de profissionais de segurança, falta de recursos materiais, a falta de autonomia para desempenhar as funções, a periculosidade do local e a relações de poder entre profissionais de segurança, saúde e as pessoas privadas de liberdade.

Essa deficiência da prestação de tal serviço faz com que os agentes de segurança penitenciária se responsabilizem por regular o acesso das pessoas privadas de liberdade aos serviços de saúde, diminuindo o critério de prioridade em relação à gravidade do problema, e, consequentemente, a qualidade da assistência prestada (CARTAXO et al., 2013).

Nota-se que a assistência à saúde está pautada em uma medicina curativa, em que a intervenção só ocorre após a instalação de uma doença ou agravo. Dessa forma, observa-se a necessidade de um maior envolvimento entre governantes em conjunto com os gestores da saúde e segurança, para de fato colocarem em prática uma assistência à saúde eficaz dentro das penitenciárias brasileiras; mas para isso é necessário uma reestruturação de todo o serviço, mudando paradigmas existentes, embasando a assistência na educação em saúde, com foco na prevenção e promoção, considerando os aspectos éticos e legais das profissões, a fim de se mitigar os preconceitos relacionados com o julgamento.

\subsubsection{Os desafios do cuidar no cárcere}

Cuidar é uma virtude que consiste em colocar-se no lugar do outro, geralmente em situações diversas, seja na dimensão pessoal ou social (SOUZA et al., 2005). O cuidado com a saúde existe desde que surgiu a vida, já que era necessário cuidar da vida para que esta pudesse se manter. Os atos de cuidados foram criadores, inovadores e geradores do saber, e por meio deles surgiram as ações práticas, que ao aos poucos viraram crenças e costumes, originando, posteriormente, os ofícios e as profissões (COLLIÈRE, 2003).

Por ser um conceito bastante abrangente, pode possibilitar múltiplos significados, a depender do contexto que está inserido; ora revela solidariedade, evidenciando 
relacionamentos compartilhados entre cidadãos em comunidades, ora transmite uma noção de obrigação, dever e compromisso social. Desse modo, a prestação de cuidados ao ser humano, de maneira solidária, holística e com interação mútua por meio das relações interpessoais, compreende um dos fundamentos da profissão de enfermagem (SOUZA et al., 2005).

\footnotetext{
"Cuidar em enfermagem consiste em envidar esforços transpessoais de um ser humano para outro, visando proteger, promover e preservar a humanidade, ajudando pessoas a encontrar significados na doença, sofrimento e dor, bem como, na existência. É ainda, ajudar outra pessoa a obter auto conhecimento, controle e auto cura, quando então, um sentido de harmonia interna é restaurada, independentemente de circunstâncias externas" (WALDOW, LOPES, MEYER, 1998, p. 38).
}

As ações inerentes à profissão de Enfermagem e às demais profissões da saúde, quer sejam administrativas ou assistenciais, são as mesmas da realidade extramuros; porém, devido às especificidades do Sistema Penal, elas se diferenciam da realidade extramuros no que se relaciona à maneira de sua aplicabilidade (SOUZA; PASSOS, 2008).

A periculosidade do Sistema Penitenciário gera tensão em profissionais de todas as áreas, devido à sua imprevisibilidade, uma vez que as pessoas privadas de liberdade possuem um único objetivo, a liberdade, e um dos meios de se alcançar esse objetivo é a fuga (VALENTE; SANTOS, 2014)

Nessa perspectiva, observa-se que o contexto de cuidar em situação de cárcere é permeado por limites e desafios, o que evidencia a importância da interdisciplinaridade no ambiente prisional, por todos os profissionais que ali atuam, independente das diferentes categorias, a fim de se obter uma assistência à saúde com segurança e proteção, tanto para esses profissionais como para as pessoas reclusas (VALENTE; SANTOS, 2014).

O encarceramento propicia características psicossociais que geram efeitos sobre a formação dos sistemas de representação, ligados à vida nos presídios e, particularmente, na situação de doença, relacionados às práticas e concepções de saúde-doença. Geralmente, essas novas características repercutem de forma negativa em relação à assistência à saúde, pois os sinais e sintomas são subvalorizados, e a busca pela assistência à saúde é prejudicada por fatores ligados ao preconceito e à exclusão (SOUZA et al., 2012).

A desvalorização da pessoa privada de liberdade e de sua queixa pelos profissionais de segurança é frequente dentro dos ambientes prisionais. Por não serem considerados confiáveis, é preciso apresentar sintomas verificáveis, sendo o sofrimento psíquico 
insuficiente para suscitar a assistência à saúde ou para evidenciar que algo está errado. Além disso, em algumas situações, a saúde é submetida à ordem disciplinar, funcionando como um elemento de troca e negociação para se manter a disciplina e a ordem nos estabelecimentos (DIUANA et al., 2008; MARTINS et al., 2014).

Doenças como a Aids, devido à sua forma de transmissão, possibilitam que os profissionais de segurança adotem medidas defensivas para se proteger dos riscos de contrair a doença, por meio da identificação e afastamento dos doentes e dos possíveis suspeitos; essa diferenciação e distância entre eles e as pessoas privadas de liberdade, baseadas na lógica das estratégias defensivas das identidades, parece proporcionar a impressão de um risco sob controle. Já a tuberculose, por sua propagação pelo ar, dificulta essa demarcação territorial, fragilizando e extrapolando as barreiras impostas, constituindo, assim, uma ameaça a todos, independente de sua identidade (DIUANA et al., 2008).

Dessa forma, os agentes de segurança penitenciária atribuem aos demais profissionais os cuidados com as pessoas privadas de liberdade, procurando desenvolver apenas o papel de segurança e vigilância envolvidos com o cárcere, evitando assim sua aproximação com o detento, o que, para muitos, seria a solução das contradições existentes entre o vigiar/punir e o assistir/prevenir (DIUANA et al., 2008).

\subsubsection{A estrutura penitenciária $X$ assistência à saúde}

A estrutura carcerária brasileira se caracteriza por apresentar um défice de vagas, ocasionado pela superlotação e/ou saturação dos estabelecimentos existentes, dificultando, em especial, a segurança e garantia do atendimento à saúde das pessoas privadas de liberdade. Esse défice, ao contrário do que se imagina, é mais acentuado nas penitenciárias femininas $(46,05 \%)$ em relação às masculinas $(39,42 \%)$, levando as mulheres a serem alojadas em locais projetados para homens, sem infraestrutura adequada para atender suas demandas específicas, como a gestação e a maternidade, que envolvem a amamentação e os cuidados com o recémnascido (CARTAXO et al., 2013).

No contexto da assistência à saúde à gestante em situação de cárcere, em um dos estudos ficou evidenciado que a assistência pré-natal, quando acontecia, era realizada em períodos mais avançados da gestação e em unidades de saúde do SUS fora do âmbito prisional (GOIS et al., 2012), necessitando de escoltas policiais e viaturas para o deslocamento até a 
unidade de saúde, gerando, assim, um obstáculo devido à escassez de recursos humanos e materiais, e pela demora da marcação da consulta (FERNANDES et al., 2014; GALVÃO, DALVIM, 2013; OLIVEIRA, NATAL, CAMACHO, 2012). Entre as entrevistadas, 77,8\% relataram não terem feito consultas de pré-natal, e das que realizaram, a média foi de apenas duas consultas (GALVÃO; DALVIM, 2013).

Outro estudo realizado com 12 mulheres privadas de liberdade, sendo nove gestantes e três puérperas, revelou que duas das gestantes ainda não haviam recebido nenhuma consulta de pré-natal até o momento da entrevista, sendo que as mesmas se encontravam na 24. ${ }^{\mathrm{a}}$ e 25 . $^{\mathrm{a}}$ semanas de gestação, respectivamente, e duas haviam iniciado o pré-natal no $3 .^{\circ}$ trimestre de gestação; a minoria delas recebeu orientações relacionadas ao aleitamento materno, cuidados com a mama e o recém-nascido, e, apesar de todas informarem que havia um espaço destinado ao binômio mãe-filho na penitenciária, este era reduzido e encontrava-se em situações precárias (PÍCOLI et al., 2014).

Nesse contexto, que diz respeito à assistência à saúde da gestante, denota-se, nos estudos anteriormente referenciados, que as recomendações do Ministério da Saúde não estão sendo levadas em consideração, pois para uma atenção pré-natal e puerperal de qualidade e humanizada são fundamentais ações de prevenção e promoção da saúde, além de diagnóstico e tratamento adequado dos possíveis problemas que podem ocorrer nesse período. O principal objetivo da atenção pré-natal e puerperal é acolher a mulher desde o início da gravidez, para assegurar, o nascimento de uma criança saudável. Diante disso, foi estabelecido o mínimo de seis consultas de pré-natal, sendo iniciado o mais precocemente possível e se estendendo até o 42. ${ }^{\circ}$ dia puerperal (BRASIL, 2006).

Em um levantamento realizado em 109 unidades prisionais do estado de São Paulo, observou-se que, apesar de todas possuírem condições estruturais de atendimento com local próprio, dispor de equipe de saúde e ter condições para solicitar exames laboratoriais e de imagens, há uma demora no processamento e na entrega desses resultados, até mesmo de exames laboratoriais colhidos na própria unidade, o que causa um grande empecilho para as ações de saúde, dificultando a tomada de decisão e início dos tratamentos (FERNANDES et al., 2014).

Quanto aos exames de imagens, além do problema já mencionado, há outra dificuldade, que é a falta de profissionais de segurança e viaturas para a encaminhar o detento até o local referenciado para sua realização; além disso, faltam medicamentos nos 
estabelecimentos de saúde das unidades prisionais, principalmente de anti-inflamatórios e benzodiazepínicos, mesmo estes estando previstos nos programas do governo (FERNANDES et al., 2014).

Já em um estudo realizado em seis unidades prisionais da Paraíba, foram constatadas inadequações nas estruturas físicas das unidades de saúde destas penitenciárias, sendo os consultórios de enfermagem os que se encontravam em situações mais precárias. Situações como essa interferem diretamente na qualidade da assistência e na biossegurança dos pacientes e profissionais que ali atuam. Outro achado importante desse estudo foi que cinco das seis unidades prisionais não possuíam estrutura arquitetônica adequada para receberem indivíduos com algum tipo de deficiência física ou mobilidade reduzida, como cadeirantes, deficientes visuais e idosos (BARBOSA et al., 2014)

Condições de trabalho precárias estão relacionadas com o não cumprimento dos direitos dos trabalhadores inseridos no contexto das penitenciárias - profissionais de saúde e de segurança -, o que também pode levar, muitas vezes, à desmotivação, ressentimentos e negação em atribuir o direito à saúde das pessoas privadas de liberdade (MARTINS et al., 2014).

Dentre as dificuldades encontradas pela equipe de enfermagem nos serviços de saúde do Sistema Penitenciário, foram ressaltados a falta de autonomia profissional, por estar condicionada ao serviço de segurança, pois a segurança é prioridade e, posteriormente, o tratamento das pessoas privadas de liberdade; a precarização dos serviços de saúde, a falta de infraestrutura das unidades de saúde prisionais e a sua dependência ao agente penitenciário para desenvolver as ações pertinentes (SOUZA; PASSOS, 2008).

Diante de tantas peculiaridades encontradas no sistema penitenciário brasileiro e mediante as situações de insegurança e medo constante, faz-se necessário treinamento específico para a atuação das equipes de saúde nesses locais, uma vez que essas equipes devem estar orientadas e preparadas para atuarem em rotas de fugas ou em eventos de múltiplas vítimas, como rebeliões e surtos epidêmicos, o que gera estresse e insatisfação pelas condições de trabalho em que estão inseridas (SOUZA; PASSOS, 2008).

\subsection{HIV/AIDS NO CÁRCERE}

\subsubsection{HIV/Aids}


O vírus da imunodeficiência humana (HIV) é um retrovírus que se espalha por meio de fluídos corporais, multiplicando-se e afetando células específicas do sistema imunológico, conhecidas como linfócitos T CD4+. Sem o tratamento com antirretroviral, o HIV afeta e destrói essas células específicas do sistema imunológico, diminuindo a imunidade do organismo, tornando-o incapaz de combater infecções e outras doenças (UNAIDS, 2016; WORLD HEALTH ORGANIZATION, 2015).

Quando há o aumento da quantidade de vírus circulante no organismo, consequentemente há uma diminuição do quantitativo dos linfócitos T CD4+, levando à Síndrome da Imunodeficiência Adquirida (AIDS) e ao aparecimento das doenças oportunistas (UNAIDS, 2016; WORLD HEALTH ORGANIZATION, 2015).

A transmissão pelo HIV ocorre pelo contato com fluidos corporais de indivíduos infectados, como o sangue, leite materno, esperma e secreções vaginais. Comportamentos e condições que colocam os indivíduos em maior risco de contrair o HIV incluem sexo desprotegido, sexo anal, uso de drogas injetáveis, compartilhamento de agulhas e seringas contaminadas ou acidentes de trabalho envolvendo as mesmas, e transfusão sanguínea com contaminação (WORLD HEALTH ORGANIZATION, 2015).

A descoberta do vírus HIV no mundo ocorreu por meio da identificação, por cientistas, de um tipo de chimpanzé na África ocidental como a fonte de infecção para HIV em humanos. Acredita-se que a versão do vírus da imunodeficiência, presentes nesses animais, foi transmitida aos seres humanos por intermédio da alimentação de sua carne contaminada pelo vírus (UNAIDS, 2016).

Estudos mostram que essa transmissão de macacos para humanos provavelmente ocorreu ainda no século XIX, e, durante décadas, o vírus se espalhou pela África e posteriormente para outras partes do mundo. Nos Estados Unidos, o vírus existe desde a metade dos anos 1970, e no Brasil, início dos anos 1980 (UNAIDS, 2016).

Atualmente, não há uma cura efetiva e segura, apenas o controle da doença por meio do tratamento frequente com a terapia antirretroviral; no entanto, os cientistas trabalham intensamente em busca de melhores resultados. Em indivíduos não tratados, o HIV é quase universalmente fatal, possuindo um tempo médio entre o contágio e o aparecimento da doença, em torno de dez anos; já em pacientes em uso da terapia antirretroviral e que possuem 
uma adesão satisfatória, sua expectativa de vida é praticamente igual à de uma pessoa não infectada (BRASIL, 2013b; UNAIDS, 2016).

A infecção pelo HIV cursa com um amplo espectro de apresentações clínicas bem definidas, desde a fase aguda até a fase mais avançada da doença. A infecção aguda ou Síndrome Retroviral Aguda (SRA) é a resposta natural do corpo à infecção pelo HIV, e apresenta-se geralmente nas primeiras semanas de infecção até o aparecimento dos anticorpos anti-HIV (soroconversão), ocorrendo entre a 2. ${ }^{a}$ e $4 .^{a}$ semana após a infecção (BRASIL, 2013b; UNAIDS, 2016).

Nessa fase, bilhões de partículas virais são produzidas diariamente, e a viremia plasmática alcança níveis elevados, e o indivíduo torna-se altamente infectante (BRASIL, 2013b; UNAIDS, 2016).

A infecção pelo HIV é acompanhada por um conjunto de manifestações clínicas, e acomete entre $50 \%$ a $90 \%$ dos indivíduos infectados, causando febre, adenopatia, faringite, exantema, mialgia e cefaleia. A maioria desses sinais e sintomas desaparece entre três a quatro semanas, porém, linfadenopatia, letargia e astenia podem persistir por vários meses (BRASIL, 2013b; UNAIDS, 2016).

Percebe-se que os sinais e sintomas que caracterizam a SRA são bastante semelhantes aos de outras infecções comuns, podendo habitualmente ser atribuídos a outra etiologia, impossibilitando o diagnóstico precoce da infecção (BRASIL, 2013b).

Outra fase característica da infecção pelo HIV é denominada de latência clínica ou fase assintomática. Nesse momento, o HIV ainda está ativo, mas se reproduz em níveis muito baixos; porém, com o passar dos anos, caso a pessoa não faça o tratamento antirretroviral, sua carga viral começa a aumentar e a contagem de linfócitos T CD4+ começa a diminuir (BRASIL, 2013b; UNAIDS, 2016).

Enquanto a contagem de linfócitos T CD4+ permanece acima de 350 células $/ \mathrm{mm}^{3}$, os episódios infecciosos mais frequentes são geralmente bacterianos, como as infecções respiratórias, dentre elas a tuberculose pulmonar. À medida que a infecção progride, e a contagem de linfócitos T CD4+ diminui, variando entre 200 e 300 células $/ \mathrm{mm}^{3}$, os sintomas como febre baixa, perda ponderal, sudorese noturna, fadiga, diarreia crônica, cefaleia, alterações neurológicas, infecções bacterianas e lesões orais, tornam-se mais frequentes, além do aparecimento de herpes-zoster (BRASIL, 2013b). 
Indivíduos que adotam uma terapia antirretroviral conseguem viver sob a latência clínica por várias décadas, podendo transmitir o vírus para outras pessoas, porém os riscos são bastante diminuídos. Já pessoas que não aderem ao tratamento, essa fase pode durar cerca de uma década, com a possibilidade de evoluir rapidamente para a Aids (BRASIL, 2013b; UNAIDS, 2016; WORLD HEALTH ORGANIZATION, 2015).

A Aids é definida pelo aparecimento de infecções oportunistas e neoplasias, devido ao comprometimento do estado imunológico, apresentando o quantitativo de linfócitos $\mathrm{T}$ CD4+ abaixo de 200 células/mm³ (BRASIL, 2013; UNAIDS, 2016). Dentre as infecções oportunistas, as mais frequentes são as pneumocistose, neurotoxoplasmose, tuberculose pulmonar atípica ou disseminada, meningite criptocócica e retinite por citomegalovírus. Neoplasias, como sarcoma de Kaposi, linfoma não-Hodgkin e câncer de colo uterino, também podem estar presentes (BRASIL, 2013b).

Além das infecções e das manifestações não infecciosas, o HIV pode causar doenças por dano direto a certos órgãos ou por processos inflamatórios, tais como miocardiopatia, nefropatia e neuropatias, que podem estar presentes durante toda a evolução da infecção (BRASIL, 2013b).

Segundo dados da World Health Organization - WHO (2015), o HIV continua sendo um grave problema de saúde pública, afetando mais de 34 milhões de pessoas, e levando à morte 1,2 milhões de pessoas no ano de 2014. A África Subsaariana é a região mais afetada, com aproximadamente 25,8 milhões de pessoas vivendo com o HIV em 2014, e também é responsável por quase $70 \%$ do total global das novas infecções pelo vírus.

Em 2014, em nível mundial, estima-se que 2,0 milhões de pessoas contraíram o vírus, e que apenas $54 \%$ das pessoas com HIV sabiam do seu estado sorológico. Aproximadamente 15,8 milhões de pessoas vivendo com HIV estavam recebendo a terapia antirretroviral (WORLD HEALTH ORGANIZATION, 2015).

Entre 2000 e 2015, a incidência do HIV diminuiu 35\%, as mortes relacionadas com a Aids diminuíram 24\%, com cerca de 7,8 milhões de vidas salvas, como resultado dos esforços internacionais em busca de melhorias do tratamento e da cura da doença (WORLD HEALTH ORGANIZATION, 2015).

Segundo o Boletim Epidemiológico HIV/Aids (2015), estima-se que no Brasil, desde o início da epidemia, em 1980, foram registrados 798.366 casos de Aids no país, sendo $615.022(71 \%)$ registrados no Sistema Nacional de Agravos de Notificação 
(SINAN), e os demais em outros sistemas de notificação. A taxa de detecção de Aids no Brasil vem estabilizando nos últimos dez anos, com uma média de 20,5 casos para cada 100 mil habitantes (BRASIL, 2015a).

Em relação ao sexo, foram registrados no Brasil, até junho de 2015, 519.183 $(65,0 \%)$ casos de Aids em homens e 278.960 (35,0\%) em mulheres. No período de 1980 até 2003, observou-se um aumento do número de casos de Aids entre a população feminina, ficando essa relação estabilizada entre o período de 2004 a 2008. No entanto, a partir de 2009, observa-se uma redução nos casos de Aids em mulheres e aumento nos casos em homens, sendo que essa relação passou a ser de 19 casos de Aids em homens para cada 10 casos em mulheres em 2014 (BRASIL, 2015a).

Nos últimos dez anos, a taxa de casos de Aids em homens aumentou de 24,7 casos para cada 100 mil habitantes, em 2005; para 27,7, em 2014, representando um aumento de 10,8\%; já entre as mulheres houve uma queda, passando de 16,3 casos a cada 100 mil habitantes, em 2005; para 13,7, em 2014, representando uma queda de 18,9\% (BRASIL, 2015a).

A maior concentração dos casos de Aids no Brasil está entre os indivíduos com idade entre 25 a 39 anos em ambos os sexos; entre os homens, essa faixa etária corresponde a 53,6 \% e entre as mulheres 49,8\% (BRASIL, 2015a).

Entre os homens, observa-se um predomínio da categoria de exposição heterossexual; porém, houve uma tendência de aumento na proporção de casos em Homens que fazem Sexo com Homens (HSH) nos últimos dez anos, passando de 34,9\%, em 2005, para 44,9\%, em 2014. A proporção de Usuários de Drogas Injetáveis (UDI) vem diminuindo ao longo dos anos em todo o país, com tendência significativa de queda (BRASIL, 2015a).

Em relação aos óbitos, tendo como causa básica a Aids, desde o início da epidemia no país até dezembro de 2014, foram identificados 290.929 óbitos, sendo $71,2 \%$ entre os homens e $28,8 \%$ entre as mulheres, evidenciando uma queda significativa nos últimos dez anos, passando de 6,0 óbitos para cada 100 mil habitantes, em 2005, para 5,7, em 2014, o que representou uma queda de 5,0\%. Porém, essa tendência não é acompanhada por todas as regiões do país, pois as regiões Norte e Nordeste apresentaram aumento da mortalidade, tendo como causa básica a Aids (BRASIL, 2015a). 


\subsubsection{Diagnóstico do HIV/Aids}

O HIV/Aids, em pleno século XXI, ainda é uma doença estigmatizada, vergonhosa e fortemente associada à desvalorização moral e social do indivíduo por ainda estar relacionada a comportamentos de risco (CARVALHO; GALVÃO; SILVA, 2010). A descoberta do diagnóstico de HIV provoca reações de tristeza, medo, e também a sensação de estar à beira da morte, tanto aos portadores como aos seus familiares (MALISKA et al., 2009).

Além desses sentimentos, há o receio da revelação do diagnóstico à rede social do indivíduo devido ao preconceito e julgamentos a serem enfrentados a partir daquele momento. Passado esse período de turbulência após o diagnóstico, surge a necessidade do enfrentamento mediante a sua nova condição, e o paciente e seus familiares percebem que é possível viver com a Aids, passando a adotar mudanças em seu cotidiano, a fim de se buscar uma melhor qualidade de vida (CARDOSO, MARCON, WAIDMANI, 2008; MALISKA et al., 2009).

$\mathrm{Na}$ atualidade, são grandes os desafios associados à implementação de testes diagnósticos pela infecção por HIV, por envolverem o planejamento de políticas públicas que incluem desde questões estruturais (políticas, custo-efetividade, etc.) até as operacionais (recursos humanos, validação dos testes e boas práticas de laboratório) (BRASIL, 2014d).

Logo após a descoberta do HIV, foram desenvolvidos imunoensaios (IE) para o diagnóstico da infecção, sendo que, nas últimas décadas, quatro gerações de IE foram desenvolvidas, além dos testes rápidos, permitindo diminuir ainda mais o período da janela imunológica do HIV, agilizando e ampliando, dessa forma, o diagnóstico, já que em nosso país mais de $95 \%$ dos casos são diagnosticados na fase crônica da infecção (BRASIL, 2014d).

Os testes para detecção da infecção pelo HIV são empregados em três situações principais, sendo para a triagem sorológica do sangue doado e garantia da segurança transfusional de hemoderivados e órgãos para transplante; para os estudos de vigilância epidemiológica; e para realizar o diagnóstico da infecção pelo HIV (BRASIL, 2014d).

Há vários tipos de testes e fluxogramas para identificação do HIV; assim, casos de infecção recente são melhor identificados com a utilização de um teste de $4 .{ }^{\text {a }}$ geração como 
teste de triagem, e, posteriormente, um teste molecular como teste confirmatório (BRASIL, 2014d).

Para ampliar o acesso ao diagnóstico, de maneira presencial, rápida e eficaz, empregam-se os testes rápidos como testes de triagem, já que estes podem ser utilizados em ambientes laboratoriais e não laboratoriais, capazes de detectar anticorpos anti-HIV em até 30 minutos (BRASIL, 2014d).

Esses dispositivos são otimizados para acelerar a interação antígeno/anticorpo, por meio de reagentes sensíveis à cor, como, por exemplo, o ouro coloidal. São ideais para fornecer resultados no mesmo dia em uma variedade de situações e locais, inclusive em populações vulneráveis. Possuem diversas formas de apresentação, podendo ser realizados com fluido crevicular gengival, mais conhecido como fluido oral, plasma ou sangue total pela punção digital (BRASIL, 2014d).

O teste rápido por fluido oral está sendo bastante utilizado no Brasil, devido à facilidade na sua execução, leitura e interpretação, agilidade no resultado e, além de simplificar a testagem do HIV por não ser invasivo, reduzindo o risco biológico, pode ser executado em qualquer local (BRASIL, 2014d).

Estudos americanos demonstram a importância de testes diagnósticos para o HIV no momento da prisão, a fim de se identificar o quanto antes os soropositivos, para que tão logo se inicie o tratamento e evite a disseminação.

O sistema prisional do estado americano da Carolina do Norte oferece, dentro da avaliação médica de rotina aos recém-chegados, a testagem voluntária para o HIV apenas para aqueles com comportamento de risco, por meio do teste ELISA, em amostras coletadas por punção venosa. Dos 54.016 detentos recebidos entre janeiro de 2004 e maio de 2006, 20.820 (38\%) foram testados para HIV durante todo o período; destes, 18.574 (89\%) foram testados na admissão. Mas a proporção testada variou de $1 \%$ a $84 \%$, entre oito diferentes unidades de acolhimento. Os autores acreditam que essa oferta de testagem de rotina pode aumentar a identificação de casos (ROSEN et al., 2009).

Já no estado de Rhode Island, o sistema prisional possui um centro unificado de admissão e triagem, avaliando cerca de 15.000 novos detentos por ano. A partir do ano de 1988, a testagem para HIV tornou-se obrigatória. Um estudo avaliou a prevalência de HIV nos detentos recebidos entre fevereiro de 1998 a fevereiro de 2000, utilizando as mesmas amostras para avaliar também a prevalência de hepatite B e C. Amostras séricas obtidas 
por punção venosa foram submetidas ao teste ELISA, confirmado com o Western Blot (MACALINO et al., 2004).

Ocorreram 5.390 admissões sequenciais nesse período, porém 4.269 indivíduos não eram reincidentes, ou seja, 1.121 indivíduos já tinham histórico de prisão. Os resultados para o HIV estavam disponíveis para 3.932 (92,1\%), com uma prevalência de 1,8\% (95\% IC=1.37, 2.19). Na análise univariada, a infecção por HIV foi relacionada à cor negra ou à origem latina, ter mais de 40 anos e ser usuário de drogas injetáveis (MACALINO et al., 2004).

No ano de 2009, nesse mesmo estado, ocorreram cerca de 17.000 admissões. Considerando que os resultados da triagem para o HIV ficavam disponíveis entre 7 a 14 dias, após processamento em laboratório fora do complexo penal, foi realizado um estudo piloto utilizando o teste rápido oral para HIV, entre setembro de 2008 e setembro de 2009 , Para aumentar a aplicabilidade de processar múltiplas amostras durante o processo de admissão e triagem, grupos de detentos consentiam em autocoletar o swab oral. Um total 1.364 detentos foram avaliados pelo projeto piloto, dos quais 98\% consentiram e realizaram o teste. Doze amostras orais foram positivas; destes, 11 depois se identificaram como sabidamente HIV positivos. Houve apenas um novo diagnóstico. Além disso, um detento que posteriormente se identificou como HIV positivo teve o teste rápido oral negativo, mas confirmado com amostra sanguínea (BECKWITH et al., 2011).

Procurando avaliar o melhor momento para a testagem após a prisão, 298 pessoas admitidas em sequência na cadeia de New Haven, Connecticut, Estados Unidos, no ano de 2008, foram também sequencialmente alocadas em três grupos: rastreamento imediato (no mesmo dia, $n=103$ ), precoce (dia seguinte, $n=98$ ) ou tardio (após 7 dias, $n=97$ ). O teste foi ofertado na forma "opt-out". No total, 130 (44\%) consentiram por escrito e realizaram o swab oral. No grupo imediato, $52(53 \%)$ aceitaram, contra $46(45 \%)$ no precoce e $32(33 \%)$ no tardio. Comparados ao grupo tardio, o grupo imediato e precoce foram significativamente mais testados. Na análise multivariada, apenas os designados no grupo imediato e os com baixa probabilidade de serem soltos foram significativamente associados a terem sido testados. Dois indivíduos obtiveram um resultado preliminar positivo, apenas um confirmado com o Western Blot. Incluindo 12 indivíduos sabidamente infectados, a prevalência do HIV foi de 4,4\% (13/298) (KAVASERY et al., 2009). 


\subsubsection{O tratamento da Aids}

Na década de 1980, mais precisamente no ano de 1986, houve a descoberta do primeiro antirretroviral, a Zidovudina, e desde então a comunidade científica desenvolve estudos frequentes, na busca pelo melhor controle e cura do HIV/Aids, obtendo várias conquistas em termos científicos, tecnológicos e humanísticos (BRASIL, 2015b; GIR, VAICHULONIS, OLIVEIRA, 2009).

Porém, mesmo com esses avanços relacionados com o HIV/Aids no Brasil e no mundo, inicialmente havia um sentimento de impotência dos profissionais à frente de tal situação, pois as pessoas, ao serem diagnosticadas, evoluíam para o óbito rapidamente, pois as alternativas terapêuticas e o conhecimento sobre a doença ainda eram limitados (GIR; VAICHULONIS; OLIVEIRA, 2009).

Após a criação do SUS e a implantação dos serviços de saúde no país, no início da década de 1990, estabeleceu-se uma rede para diagnóstico, aconselhamento e tratamento da infecção pelo HIV e da Aids, sendo esta estruturada em diferentes níveis assistenciais como os Centros de Testagem e Aconselhamento (CTA), os Serviços Ambulatoriais especializados em HIV e Aids (SAE), as Unidades Dispensadoras de Antirretrovirais (UDM), os Hospitais-Dia (HD) e os serviços de Assistência Domiciliar Terapêutica (ADT) (HALLAL et al., 2013).

O Brasil considera o acesso universal ao tratamento e à prevenção de DST e Aids um direito da população garantido pelo governo por meio do Ministério da Saúde no âmbito do Sistema Único de Saúde, sem custo a todos que dele necessitem, demonstrando que mesmo em países em desenvolvimento é possível promover o acesso universal ao tratamento com equidade, independentemente de raça, gênero ou condição social (HALLAL et al., 2013).

A instituição da terapia antirretroviral (TARV) não tem por objetivo erradicar a infecção pelo HIV, mas sim diminuir a morbidade e mortalidade das PVHA, diminuindo o número de frequências das internações, e, consequentemente, melhorando a qualidade e a expectativa de vida; porém, requer uma rígida adesão por parte dos pacientes (BRASIL, 2013b; GEOCZE, et al., 2010; GIR, VAICHULONIS, OLIVEIRA, 2009). Nesse sentido, pode-se afirmar então que a Aids passou a ser considerada uma doença crônica em países onde o acesso ao tratamento antirretroviral é uma realidade (POLEJACK; SEIDL, 2010). 
Nesse contexto, considera-se que a adesão adequada ao tratamento com antirretrovirais é um dos grandes desafios no controle da doença, tanto para o paciente quanto para a equipe de saúde (FIUZA et al., 2013), pois a adesão vai muito além da tomada da medicação; por ser compreendida como um processo dinâmico, multideterminado e de corresponsabilidade entre paciente e equipe de saúde (PADOIN et al., 2011; POLEJACK, SEIDL, 2010), está diretamente vinculada ao acesso e retirada da medicação na data prescrita, comparecimento às consultas, frequência e realização de exames laboratoriais; e, além disso, esta é influenciada diretamente por fatores biopsicossociais (FIUZA et al., 2013; PADOIN et al., 2011).

Atualmente, existem vários métodos para se aferir a adesão, podendo incluir medidas indiretas e diretas. Entre as medidas indiretas, destacam-se o autorrelato, o monitoramento eletrônico de medicamentos, a contagem de comprimidos e os registros de retirada de medicamentos nas farmácias de dispensação; já nas medidas diretas, podemos incluir a detecção dos medicamentos antirretrovirais ou de seus metabolizadores no sangue (POLEJACK; SEIDL, 2010).

Mesmo com os métodos existentes para monitorar e medir a adesão, não há como garantir um padrão de adoção satisfatório devido às peculiaridades e especificidades de cada método (POLEJACK; SEIDL, 2010).

Estudo realizado por Fiuza et al. (2013) demonstrou que 35,4\% dos pacientes investigados deixaram em algum momento de suas vidas, de aderirem ao tratamento antirretroviral devido a questões psicológicas ou por causa dos efeitos colaterais.

Outro estudo demonstrou que, apesar de os pacientes terem conhecimento sobre a doença e sobre a necessidade do tratamento, muitos deles não apresentavam adesão, sendo possível identificar como fatores determinantes, o conhecimento do motivo do tratamento; conhecimento sobre carga viral; bebidas alcoólicas; quantidade de comprimidos; efeitos colaterais; coincidência entre horário de trabalho e horário de ingerir alguma dose do medicamento; tempo de acompanhamento no serviço; comparecimento às consultas; e necessidade de que alguém acompanhar o paciente ao serviço de saúde (GEOCZE et al., 2010).

Sabe-se que a adesão ao tratamento antirretroviral está ligada diretamente aos aumentos dos níveis de linfócitos T CD4+, e consequentemente diminuição da carga viral. Essa evidência pôde ser comprovada por um estudo com 61 pacientes portadores de 
HIV/Aids no município de Marília - SP, pelo qual constatou-se que os pacientes aderentes possuíam cinco vezes mais chances de ter contagem de CD4+ maior que 200 cels $/ \mathrm{mm}^{3} \mathrm{em}$ relação aos não aderentes, e a carga viral indetectável foi quase seis vezes maior entre os aderentes quando comparados aos não aderentes, representando 62,8\% com carga viral < 80 cópias/ ml (ILIAS; CARANDINA; MARIN, 2011).

Anteriormente, a terapêutica antirretroviral era indicada para pessoas assintomáticas com contagem de linfócitos CD4+ $<350$ células/mm3 (HALLAL et al., 2013). Atualmente, vários estudos clínicos desenvolvidos demonstram que o início precoce da terapia antirretroviral possui um impacto favorável no aumento dos níveis de linfócito T CD4+, sendo recomendando estimular início imediato da TARV para todas as PVHA, se possível logo após o diagnóstico, independentemente da contagem de linfócitos T CD4+ (BRASIL, 2013b).

Os avanços na terapia antirretroviral levaram ao aumento progressivo nas taxas de resposta terapêutica. Inúmeros estudos mostram que aproximadamente $80 \%$ dos pacientes alcançam carga viral plasmática inferior a 50 cópias $/ \mathrm{mL}$ após um ano de tratamento e que a supressão viral se mantém ao longo do tempo, demonstrando a durabilidade da TARV tanto para terapia inicial quanto para esquemas de resgate (BRASIL, 2013b).

A terapia inicial deve sempre incluir combinações de três antirretrovirais, sendo dois da classe dos Inibidores Nucleosídeos da Transcriptase Reversa (INTR), associados a um Inibidor Não Nucleosídeos da Transcriptase Reversa (INNTR). Dessa forma, no Brasil, recentemente foi instituído o tratamento combinado, sendo este o esquema de primeira escolha, composto pelas medicações Tenofovir, Lamivudina e Efavirenz, conhecido popularmente como 3 em 1 (BRASIL, 2013b).

Com o objetivo de se avaliar as vantagens do tratamento antirretroviral com dose fixa combinada em relação ao regime de comprimidos separados, em 2013 foi realizada uma revisão sistemática com informações sobre 27.230 pacientes, demonstrando preferência à medicação combinada em dose fixa, melhor aderência entre os pacientes que receberam a medicação combinada e também melhor supressão virológica entre estes (RAMJAN et al., 2014).

Outra revisão sistemática, envolvendo 35 publicações, realizada entre os meses de novembro e dezembro de 2014, também encontrou resultados positivos em relação ao uso do tratamento com dose fixa combinada, com maior aderência pelos pacientes e melhor 
supressão virológica; a contagem de linfócitos T CD4+ não apresentou diferenças significativas. Além disso, pôde-se constatar também menos alterações laboratoriais nos exames dos pacientes em uso da medicação combinada e diminuição dos custos relacionados com o tratamento e a doença (CLAY et al., 2015).

A simplificação e adequação do esquema terapêutico, levando em consideração o perfil biopsicossocial do indivíduo, bem como suas rotinas diárias e hábitos de vida, são fundamentais para aumentar a adesão à terapêutica ARV (GIR; VAICHULONIS; OLIVEIRA, 2009).

O enfermeiro, como membro da equipe interdisciplinar, deve primar pela individualização do paciente, considerando cada indivíduo como único de acordo com suas características e especificidades, sensibilizando-o a minimizar fatores intervenientes negativos, por meio de orientações específicas sobre cada medicamento, os benefícios com alimentação, sono e repouso, atividade física e demais hábitos de promoção da saúde. Assim, poderá contribuir efetivamente, enquanto membro da equipe interdisciplinar, para a avaliação e indicação do esquema mais apropriado para o paciente (GIR; VAICHULONIS; OLIVEIRA, 2009).

\subsubsection{HIV/Aids nas penitenciárias brasileiras}

Os dados da prevalência de HIV em pessoas privadas de liberdade no Brasil surgiram desde o final da década de 1980 e ainda não se tem uma estatística da realidade do país, devido à baixa priorização de estudos epidemiológicos com essa população (COELHO et al., 2007). No entanto, a escassez de dados aponta para o fato de que o HIV/Aids no sistema penitenciário brasileiro está vinculado à origem socioeconômica, baixa escolaridade, relações conflituosas com a família e sociedade, frequências de práticas de risco associadas à patologia (ALQUIMIM, 2014; CAMARGO et al., 2012; COELHO et al., 2007), e, juntamente com esses determinantes sociais, soma-se a precariedade do sistema prisional brasileiro, que impossibilita o desenvolvimento de programas educativos e de promoção à saúde eficazes para esta população (COELHO et al., 2007).

Em estudo realizado em uma penitenciária feminina de São Paulo com 290 mulheres privadas de liberdade, pôde-se concluir que, apesar do risco de comportamento relacionado com a utilização de drogas injetáveis (UDI) na população carcerária estar associado com a 
infecção pelo vírus HIV, as variáveis relacionadas com o comportamento sexual, como sexo desprotegido, sexo com parceiros HIV, e outros, compõem o grupo de variáveis mais importantes na transmissão da doença (STRAZZA et al., 2007).

Segundo dados de um estudo realizado em 2003, na penitenciária de Ribeirão Preto, pôde-se constatar que, dos 333 participantes, 19 possuíram sorologia positiva para HIV, o que representa uma prevalência de $5,7 \%$, taxa esta quase sete vezes maior que a estimada na população masculina brasileira em geral. Mais de $40 \%$ dos participantes relataram nunca terem sido testados para o HIV anteriormente. Em relação a fatores de risco, $81 \%$ possuíam histórico de uso de drogas não injetáveis, sendo a maconha a mais utilizada; e 29\% relataram uso de drogas injetáveis ilícitas (COELHO et al., 2007).

Em penitenciárias do Mato Grosso do Sul, foi desenvolvido um estudo com 3.365 presidiários alojados em oito prisões masculinas e quatro femininas, demonstrando uma prevalência de $1,8 \%$ para o HIV, não havendo diferença significativa entre homens e mulheres. Dos participantes, 50\% relataram não terem parceiros regulares, assim como a maioria não utilizava o preservativo regularmente; $3 \%$ se declararam homossexuais, e dos que se declararam heterossexuais, $9 \%$ já tiveram relações homossexuais; em relação ao uso de drogas, $52 \%$ relataram fazerem uso de drogas não injetáveis e apenas $1 \%$ utilizou drogas injetáveis; quanto ao teste prévio de HIV, $46 \%$ de todos os participantes relataram nunca terem feito o teste (CAZANTI; ENNE; CRODA, 2014).

Outro estudo realizado no Presídio Central de Porto Alegre, por Prellwitz et al. (2013), concluiu que seis das sete (86\%) pessoas privadas de liberdade portadoras de HIV/Aids em tratamento com ARVS apresentaram falência virológica durante a pesquisa, e isso demonstrou a probabilidade de subnotificação da utilização do medicamento ARV, o fornecimento deficiente dessas medicações, a baixa aderência e um irregular acompanhamento por profissionais de saúde.

Já segundo Camargo et al. (2012), as situações e vivências no decorrer da vida de mulheres soropositivas privadas de liberdade influenciam comportamentos por vezes negligentes em relação à sua saúde, tanto na prevenção como no tratamento. Na penitenciária onde se desenvolveu o estudo, o tratamento e assistência às mesmas são oferecidos corretamente em busca de uma melhor qualidade de vida, mas muitas vezes não por iniciativa própria, e sim por determinação da instituição prisional, sugerindo que essa população se 
estivesse em situação de liberdade não conduziriam o seu tratamento de forma regular e adequada conforme o preconizado.

Ante as várias peculiaridades e limitações do sistema prisional e as altas taxas de infecções pelo HIV nesses ambientes, deve-se levar em consideração que a grande maioria dessa população irá se reintegrar à sociedade no futuro (UNAIDS, 2007); e dessa forma, fazem-se necessários esforços dos formuladores de políticas públicas para se reduzir a transmissão do HIV/Aids em ambientes prisionais, por meio de ações de promoção e prevenção da saúde, oferta de testes de triagem aos que ingressam nos presídios e iniciativas de adesão ao tratamento ARV, com o intuito de almejar a melhoria da qualidade de vida dessa população e dos profissionais que ali trabalham, além de também contribuir para a redução do avanço da infecção na sociedade em geral (PRELLWITZ et al., 2013; UNAIDS, 2007).

\subsection{PROMOÇÃO DA SAÚDE}

\subsubsection{Contextualizando a promoção da saúde}

A assistência multidisciplinar, foco das discussões em saúde, almeja romper com o modelo biomédico fragmentado e pouco resolutivo e pactuar com uma assistência direcionada à promoção, prevenção, proteção e reabilitação em saúde. As ações de enfermagem são direcionadas ao cumprimento desses princípios e, para tal, é necessária a aplicação de uma teoria de enfermagem (GUEDES et al., 2009).

$\mathrm{Na}$ década de 70, devido às grandes críticas do modelo assistencial de saúde vigente no mundo, centrado apenas no modelo médico-hospitalar, e em uma medicina voltada para a medicalização, fez-se com que uma nova concepção de saúde surgisse e fosse tema de várias discussões. Com isso, em 1974, no Canadá, com a divulgação do documento denominado Informe Lalonde - "Uma nova perspectiva sobre a saúde dos canadenses", iniciaram-se discussões sobre o assunto (BUSS, 2000).

Logo em seguida, em 1978, houve a I Conferência Internacional sobre Cuidados Primários de Saúde, em Alma-Ata, cuja meta foi "Saúde para todos no ano 2000". O conceito de promoção da saúde tornou-se mais difundido em 1986, com a divulgação da Carta de Otawa na I Conferência Internacional de Promoção da Saúde, que definia promoção da saúde 
como "processo de capacitação da comunidade para atuar na melhoria da sua qualidade de vida e saúde, incluindo uma maior participação no controle deste processo" (HEIDMANN et al., 2006; BRASIL, 2002; BUSS, 2000).

Decorrentes disso, sete conferências internacionais sobre a promoção da saúde foram organizadas, devido à relevância e magnitude do tema; dentre elas podemos citar a de Adelaide, em 1988 (Políticas Públicas Saudáveis), Sundsvall, em 1991 (Ambientes Favoráveis à Saúde), Jacarta, em 1997 (Reforço da Ação Comunitária), Cidade do México, em 2000 (reforçou a importância das ações de promoção da saúde), Bangkok, em 2005 (reforçou as mudanças no conceito de saúde global), Nairóbi, em 2009 (estratégias chave e compromissos urgentes para aplicação da saúde e no desenvolvimento), e Helsinque, em 2013 (Saúde em todas as Políticas) (HEIDMANN et al., 2006; BRASIL, 2002; BUSS, 2000).

Houve também, concomitantemente a esses fatos marcantes, a realização das conferências regionais, sub-regionais e específicas de promoção à saúde, inclusive nas Américas, trazendo formalmente o tema e novas propostas para as sub-regiões do mundo (BRASIL, 2002; HEIDMANN et al., 2006).

Com os avanços das discussões dos temas e das pesquisas realizadas durante os anos, a conceituação de promoção da saúde foi se modificando, segundo Buss (2000), o conceito de promoção da saúde pode ser reunido em dois grandes grupos, sendo o primeiro relacionado às atividades dirigidas à transformação de comportamentos individuais com o foco na mudança dos estilos de vida, com a adoção de hábitos saudáveis, localizando-os no ambiente familiar; já o segundo sustenta que a saúde é produto de um amplo espectro de fatores que estão relacionados com os determinantes sociais da saúde (alimentação, moradia, renda, educação, trabalho, saneamento básico, habitação), sendo suas ações direcionadas ao coletivo e ao ambiente físico, social, político, econômico e cultural, por meio das implantações de políticas públicas que visam condições favoráveis ao desenvolvimento da saúde.

Diante deste novo cenário no que diz respeito à Promoção da Saúde, o Ministério da Saúde instituiu a Política Nacional de Promoção da Saúde (PNPS) através da Portaria MS/GM $\mathrm{n}^{\circ} 687$ de 30 de março de 2006, que vem sendo alvo de grandes revisões e adota como conceito de Promoção da Saúde:

"Conjunto de estratégias e formas de produzir saúde, no âmbito individual e coletivo, que se caracteriza pela articulação e cooperação intrassetorial $e$ 
intersetorial e pela formação da Rede de Atenção à Saúde, buscando se articular com as demais redes de proteção social, com ampla participação e amplo controle social. Assim, reconhece as demais políticas e tecnologias existentes visando à equidade e à qualidade de vida, com redução de vulnerabilidades e riscos à saúde decorrentes dos determinantes sociais, econômicos, políticos, culturais e ambientais" (BRASIL, 2015c, p. 7).

A PNPS possui como objetivo promover a equidade e a melhoria das condições e dos modos de viver, ampliando a potencialidade da saúde individual e coletiva e reduzindo vulnerabilidades e riscos à saúde decorrentes dos determinantes sociais, econômicos, políticos, culturais e ambientais (BRASIL, 201c).

Como uma de suas essências, a PNPS estabelece relações com outras políticas públicas vigentes, podendo destacar as do setor saúde como: a Política Nacional de Atenção Básica (Pnab), a Política Nacional de Alimentação e Nutrição (Pnan), a Política Nacional de Educação Popular em Saúde (Pnep-SUS), a Política Nacional de Humanização (HumanizaSUS), a Política Nacional de Gestão Estratégica e Participativa (ParticipaSUS), a Política Nacional de Práticas Integrativas e Complementares (PNPIC), a Política Nacional de Redução da Morbimortalidade por Acidentes e Violências, a Política Nacional de Atenção às Urgências, e as Políticas Nacionais de Saúde Integral de Populações Específicas, como as da população negra, da população LGBT e da população privada de liberdade (BRASIL, 2015c).

\subsubsection{O Modelo de Promoção da Saúde, de Nola J. Pender}

As teorias de enfermagem fornecem subsídios para uma assistência embasada em princípios científicos, e dessa forma busca a compreensão dos indivíduos em sua plenitude. A primeira teoria/filosofia de enfermagem empregada indiretamente por Florence Nightingale visou a organização do trabalho e do ambiente, com intuito de prestar uma assistência qualificada; já em 1975, surgiram as primeiras concepções da Teoria de Promoção da Saúde, de Nola Pender, instituída anos após; seus princípios são enfatizados até os dias atuais (PENDER, MURDAUGH, PARSONS, 2002).

O Modelo de Promoção da Saúde, de Nola Pender (MPS), possui como bases e fontes teóricas a perspectiva de enfermagem holística, da psicologia social e da teoria de aprendizagem. O modelo integra diversos constructos, e, baseado na Teoria Cognitiva Social, 
postula a importância dos processos cognitivos na alteração comportamental, que inclui as seguintes crenças: autoatribuição, autoavaliação e autoeficácia (TOMEY; ALLIGOOD, 2004).

O MPS é semelhante ao Modelo de Crença na Saúde, porém não possui como objetivo estudar o comportamento de prevenção da doença, excluindo assim o medo ou ameaça como fonte de motivação para o comportamento de saúde. Esse modelo relaciona-se com comportamentos para melhorar a saúde e aplica-se potencialmente ao longo do ciclo vital, e os pressupostos dessa teoria refletem a perspectiva da ciência comportamental e enfatizam o papel ativo do paciente na gestão dos comportamentos de saúde, alterando o contexto ambiental (TOMEY, ALLIGOOD, 2004).

Dessa forma, o Modelo de Promoção da Saúde Nola Pender vem de encontro a PNPS, no que diz respeito à atenção e ao cuidado com a saúde, pois torna-se uma estratégia de produção de saúde que respeita as especificidades e as potencialidades, através da escuta qualificada dos trabalhadores e dos pacientes, de modo a modificar a atenção da perspectiva estrita do adoecimento para o acolhimento de suas histórias e condições de vida, possibilitando assim a identificação dos fatores e condições de vulnerabilidades, os riscos e as potencialidades de saúde que afetam a vida da população (BRASIL, 2015c).

O Modelo de Promoção da Saúde pode ser usado para implementar e avaliar ações de promoção da saúde, por meio da análise de três categorias principais, sendo elas as características e experiências individuais; os sentimentos e conhecimentos sobre o comportamento; e o resultado do comportamento de promoção da saúde desejável, que estão claramente definidas em um diagrama simples (FIGURA 1) e de fácil compreensão, que permite associar estas categorias com o resultado esperado (TOMEY, ALLIGOOD, 2004).

- As características e experiências individuais compreendem o comportamento anterior, que são as vivências de comportamentos anteriores relacionados, que pode interferir positivamente ou negativamente nos comportamentos de promoção da saúde, e também aos fatores pessoais, que são preditores de um dado comportamento e são analisados de acordo com os fatores biológicos, psicológicos e socioculturais (TOMEY, ALLIGOOD, 2004; VICTOR, LOPES, XIMENES, 2005).

- O núcleo central do diagrama de Pender, sentimentos e conhecimentos sobre o comportamento, relaciona-se com os benefícios para a ação, resultados positivos que reforçam os benefícios que serão adquiridos por meio da adoção de determinado 
comportamento de saúde; barreira á ação, bloqueios antecipados, imaginados ou reais, de determinado comportamento; autoeficácia, julgamento da capacidade pessoal para organizar e executar um comportamento de promoção da saúde; sentimento em relação ao comportamento, sentimentos positivos ou negativos que interferem diretamente antes, durante e a seguir ao comportamento adotado; influências interpessoais, que são os conhecimentos relativos aos comportamentos, crenças ou atitudes de outras pessoas ou normas e modelos sociais que podem interferir positivamente ou negativamente; influências situacionais, interferência do ambiente facilitando ou impedindo determinado comportamento de saúde (TOMEY, ALLIGOOD, 2004; VICTOR, LOPES, XIMENES, 2005).

FIGURA 1 - DIAGRAMA DO MODELO DE PROMOÇÃO DA SAÚDE, DE NOLA J. PENDER

\section{Caracteristicas}

3. Resultado do Comportamento

e experiências individuais

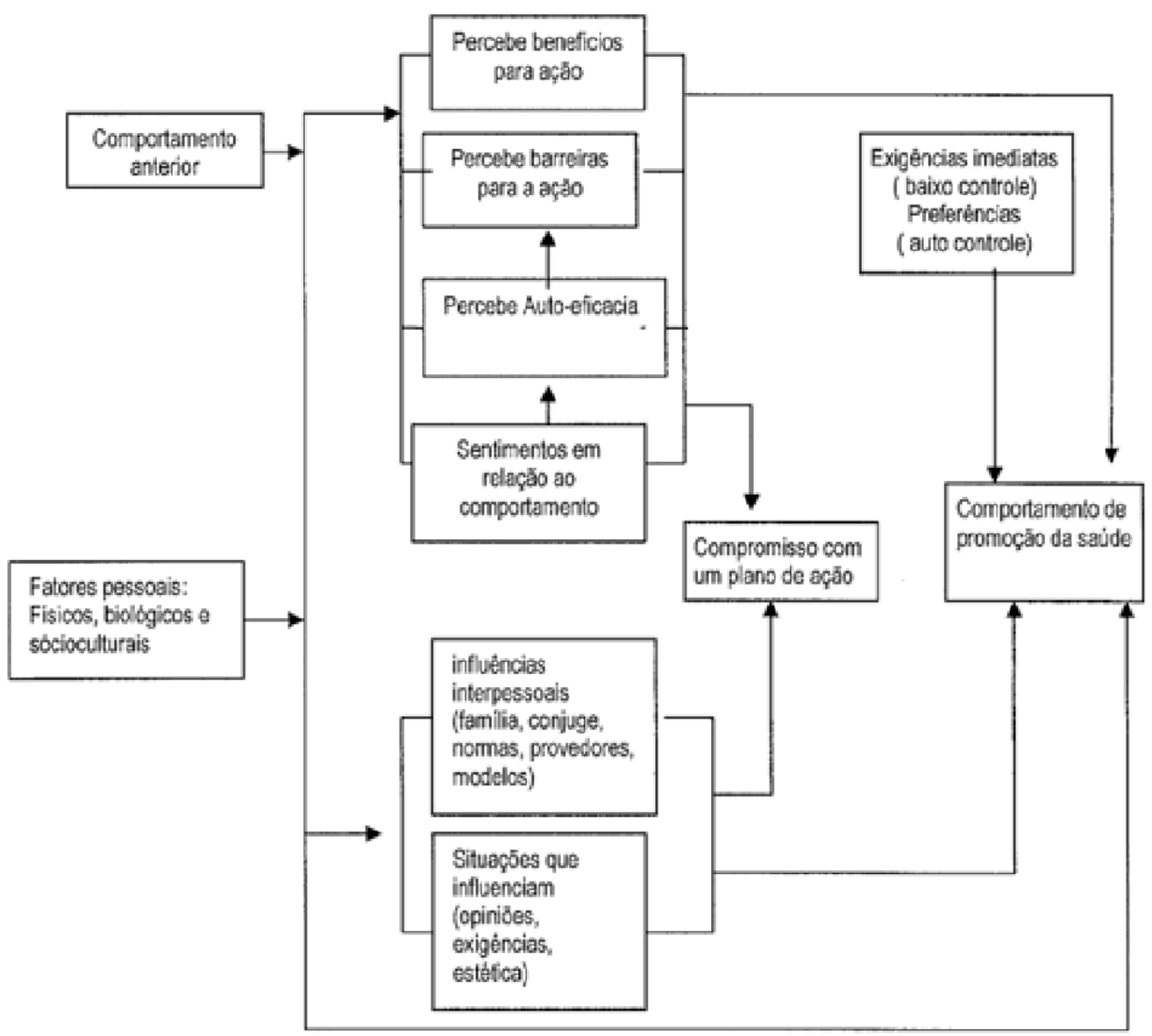

FONTE: Tomey; Alligood, 2004. 
- A terceira e última categoria, resultado do comportamento de saúde de promoção da saúde, abrange o compromisso com o plano de ação, que são as intenções e metas que conduzem ao comprometimento da realização de um comportamento de saúde, ou seja, as intervenções de enfermagem; exigências imediatas e preferências - as exigências imediatas são fatores que os indivíduos possuem controle reduzido sobre eles, porque existem contingências ambientais que interferem na decisão; já as preferências exercem um alto controle sob as ações de mudanças de comportamento, pois dependem exclusivamente do indivíduo; comportamento de promoção da saúde, fỉm ou resultado da ação orientado com o intuito de se obter resultados positivos na saúde, aumento da qualidade de vida, realização pessoal e existência produtiva (TOMEY, ALLIGOOD, 2004; VICTOR, LOPES, XIMENES, 2005).

A validação da teoria ocorreu por meio de estudos e pesquisas, servindo de subsídio para o "Health Promoting Life Style Profile" e para o "Exercise Benefit/Barriers Scale" (EBBS), em que ambos serviram para testar e desenvolver o MPS, sendo o primeiro utilizado para se medir os estilos de vida relacionados com a promoção da saúde, e o EBBS para avaliar os fatores cognitivos e perceptivos dos benefícios e das barreiras à atividade física (TOMEY; ALLIGOOD, 2004).

Dessa teoria, emergiram-se 14 postulados, e dentre estes podemos sintetizar de tal forma que o comportamento anterior e as características herdadas e adquiridas influenciam as crenças, a afetação e regulamentação do comportamento de promoção da saúde; ou seja, caso esses comportamentos sejam dotados de sentimentos negativos, menor será a autoeficácia percebida, maiores serão as barreiras e menores os benefícios; isso compromete negativamente o compromisso com o plano de ação e, consequentemente, no comportamento de promoção da saúde. O contrário também pode ocorrer, aumentando a probabilidade da adoção do comportamento de saúde, desde que não seja interferido pelas exigências imediatas ou preferências (SILVA; SANTOS, 2010).

Ainda relacionado aos postulados, constata-se que as pessoas se comprometem a terem um comportamento de saúde de acordo com as vantagens pessoais que este comportamento pode lhes oferecer, e dessa forma também podem alterar os conhecimentos, a apresentação e os ambientes interpessoal e físico para criar incentivos a ações de saúde (SILVA; SANTOS, 2010). 
A corresponsabilização do paciente sobre a sua saúde é outro fator trabalhado na teoria, pois acredita-se que sua participação ativa e as inter-relações com os profissionais de saúde são ações importantes no processo de adoecimento (SILVA; SANTOS; BERARDINELLI, 2013).

Percebe-se que o modelo de promoção da saúde pode ser aplicado nas diferentes fases do ciclo vital e em diversas situações, tanto em pacientes saudáveis, trabalhadores, quanto em pacientes que possuem uma patologia pré-existente, fatos estes semelhantes aos estudos realizados por Pender e suas colegas, ao validarem o Modelo de Promoção da Saúde (SILVA; SANTOS, 2010).

A teoria de Nola Pender, no Brasil, ainda é pouco utilizada, mas, por meio das publicações existentes, constata-se a relevância dessa teoria, podendo perceber que os estudos direcionam-se a crianças, adolescentes, idosos, adultos trabalhadores, mulheres gestantes e adultos, com patologias distintas, evidenciando, assim, a capacidade de abrangência desse diagrama em todo o ciclo vital e consequentemente em todos os níveis de atenção à saúde.

Em estudo relacionado com a prática de atividade física em escolares com idade entre seis e 18 anos, constatou-se que os fatores pessoais bem como o comportamento anterior relacionado interferem na prática de atividade física das crianças e adolescentes, uma vez que estes gastam muito tempo do dia em atividades sedentárias, as quais podem ser relacionadas com o sobrepeso e a obesidade; quanto ao sexo, as meninas foram mais sedentárias do que os meninos, e quanto à idade os adolescentes apresentaram-se mais ativos. Observou-se que um número considerável de integrantes do grupo desenvolvia atividades físicas extraescolares em locais abertos e públicos, não demandando assim uma boa infraestrutura e nem gastos econômicos (SILVA; SANTOS; BERARDINELLI, 2010).

No caso de crianças com cardiopatias congênitas, devem-se considerar os fatores ambientais, socioculturais e psicológicos, objetivando adaptar uma alimentação saudável para a criança em ambientes hospitalares e principalmente fora destes durante o seu dia a dia, pois uma nutrição adequada constitui um diferencial eficaz para a recuperação e manutenção da sua qualidade de vida. Sendo assim, é necessário que se avaliem as fragilidades e potencialidades para a adoção desse comportamento e, caso necessário, fazer as intervenções apropriadas, corresponsabilizando também as famílias em relação à importância do seu papel na promoção da saúde dessas crianças (GUEDES et al., 2009). 
Ao avaliar a promoção da saúde sexual de mulheres estomizadas, pode-se perceber que o Modelo de Promoção da Saúde proposto por Pender conseguiu identificar vários fatores que interferiam nessa conduta, pois a grande maioria das mulheres entrevistadas possuía várias fragilidades após a descoberta da doença e a realização da cirurgia, dificultando bastante a adoção das práticas de promoção da saúde sexual, ficando evidenciada a necessidade de ações compartilhadas na busca pela promoção da saúde sexual e reprodutiva com mulheres com estomas (MARTINS, 2013).

Já um estudo realizado com 60 profissionais da equipe de enfermagem quanto à utilização de luvas para punção venosa, administração de medicamentos em injetores laterais de equipo e retirada de agulhas e cateter intravenoso, constatou-se que, após treinamento utilizando a teoria de promoção da saúde, os profissionais relataram que adotariam o uso de luvas com maior frequência em tais procedimentos, passando de 58,3\% para 83,3\%,18,33\% para $71,66 \%$, e de $61,66 \%$ para $90 \%$, respectivamente. Outro dado muito interessante foi que 90\% dos participantes relataram que a partir daquele momento iriam encorajar os demais colegas de trabalho a utilizarem as luvas com maior frequência para realizar tais procedimentos. Dessa forma, constata-se que o modelo é possível de alterar comportamentos em instituições de serviços que zelam pela proteção e bem-estar dos trabalhadores (MARZIALE et al., 2010).

Autoestima e automotivação relacionam-se diretamente com o comprometimento do paciente em relação às ações de promoção da saúde propostas pelo enfermeiro. Em um grupo de idosos, foi investigada a relação entre autoestima e a prática de atividade física, sendo observado que os idosos praticantes de algum tipo de atividade, que mesmo com comorbidades associadas, mantêm autoestima elevada quando comparados com os não praticantes (SANTOS, I. et al., 2011).

Porém, há situações em que a falta de conhecimento, as condições socioeconômicas e as situações influenciadoras se convergem em barreiras impeditivas, dificultando as práticas comportamentais de promoção da saúde. Em estudos realizados com portadores de coronoariopatias e obesidade, por meio dos relatos, identificaram-se fatores facilitadores e fatores dificultadores, sendo estes mais frequentes, podendo destacar a inobservância em relação à dor no peito, falta de atividade física, dieta não balanceada, baixa condição financeira, níveis reduzidos de escolaridade, relações de conflito familiar e perda de alguém significativo (SILVA; SANTOS; BERARDINELLI, 2013). 
A simplicidade da teoria de Nola Pender, assim como a fácil aplicação do diagrama, fornecem subsídios para uma assistência integral e qualificada. A consulta de enfermagem é um instrumento valioso na assistência de enfermagem, bem como na implementação das ações de promoção da saúde (SILVA; SANTOS, 2010). Mesmo que o Modelo de Promoção da Saúde possibilite um fácil entendimento pela praticidade e objetividade, alguns autores relatam limitações para a sua aplicação no que se refere à tradução de alguns componentes e variáveis do modelo, que podem induzir a erros de interpretação e uma aplicação equivocada (SILVA; SANTOS, 2010).

Dessa forma, o modelo permite a implementação de intervenções de enfermagem de modo organizado e sistematizado no âmbito da promoção da saúde, em se tratando de mudanças no comportamento. Estudos que envolvem aplicação de teorias de enfermagem facilitam a aproximação dos enfermeiros com as bases teóricas da sua ciência e, consequentemente, de seus constructos, facilitando uma prática baseada em escolhas e adequações comprovadas cientificamente (SILVA; SANTOS, 2010).

Mediante as ações de promoção da saúde, o enfermeiro, como integrante da equipe multiprofissional, destaca-se como transformador e multiplicador de conhecimento com vistas a contribuir no processo educativo e preventivo, uma vez que essa temática está cada vez mais difundida nas ações de saúde pública do país. Destaca-se, então, a necessidade de os enfermeiros reconhecerem a importância das bases teóricas para o fortalecimento científico da profissão, e assim prestarem uma assistência integral e resolutiva, cujo enfoque envolva a interação entre o paciente e o profissional. 


\section{MÉTODO}

\subsection{TIPO DE ESTUDO}

Trata-se de uma pesquisa social em saúde, exploratória e descritiva, baseada na abordagem qualitativa, interpretada à luz da Teoria da Promoção da Saúde, de Nola Pender.

A pesquisa social em saúde representa as várias maneiras de investigação de saúde/doença, e busca compreender o ser humano em sociedade por intermédio dos vários atores do meio que estão inseridos no convívio social dos indivíduos, sejam eles instituições políticas e de serviços, bem como os profissionais e usuários (MINAYO, 2008).

A metodologia qualitativa aplicada à saúde busca compreender o significado e a realidade da vida individual ou coletiva com toda a riqueza de significados que transborda dela (MINAYO, 2002). Conhecer os significados dos fenômenos do processo saúde-doença é essencial para melhorar a qualidade da relação entre o paciente e o profissional de saúde; promover maior adesão a determinados tratamentos individuais ou coletivos; entender mais profundamente certos sentimentos, ideias e comportamentos dos pacientes e de seus familiares (TURATO, 2005).

Esse tipo de método, além de desvendar processos pessoais ainda pouco explorados, propicia também novos conhecimentos e conceitos, e consequentemente a elaboração de hipóteses, indicadores de qualidade, variáveis e tipologias (MINAYO, 2008).

\subsection{LOCAL DO ESTUDO}

O local de estudo foi o Presídio Masculino do Distrito Federal II (PDF II) do Complexo Penitenciário do Distrito Federal - Papuda, localizada na região administrativa de São Sebastião - Distrito Federal, Rodovia DF 465 - km 4. O PDF II foi definido como campo de pesquisa pelo fato de o pesquisador não possuir vínculo com esses pacientes.

No momento das entrevistas o PDF II possuía uma população de 3.206 pessoas privadas de liberdade, porém disponibilizava apenas 1.464 vagas, evidenciado assim a situação de superlotação do local. 
A população portadora de HIV/Aids no local era constituída por 13 pacientes, sendo que 12 encontrava-se em sistema fechado de detenção e um em sistema provisório de detenção.

\subsection{PARTICIPANTES DO ESTUDO}

O Complexo possuía, no momento da pesquisa, aproximadamente 65 pacientes portadores do HIV/Aids, o que representava $0,6 \%$ da população total. Destes, 35 portadores de HIV/Aids cumpriam pena em regime fechado (23 no PDF I e 12 no PDF II), representando 54\% dos casos de PVHA no Complexo Penitenciário do Distrito Federal.

Neste estudo, foram entrevistados 12 pacientes portadores de HIV/Aids que estão sob regime fechado de detenção, alojados no PDF II, o que representou no momento $18,5 \%$ da população total de PVHA.

\subsection{CRITÉRIOS DE INCLUSÃO}

Como critérios de inclusão, adotaram-se pessoas maiores de 18 anos privadas de liberdade, portadoras de HIV/Aids, do sexo masculino, reclusas em regime fechado de detenção no PDF II, cadastradas no referido local há pelo menos um ano.

\subsection{CRITÉRIOS DE EXCLUSÃO}

Foram excluídas do estudo as pessoas maiores de 18 anos privadas de liberdade, portadoras de HIV/Aids, que estavam em regime provisório ou semiaberto de detenção.

\subsection{PROCEDIMENTO DE COLETA DE DADOS}

Após a aprovação no Comitê de Ética em Pesquisa da Fundação de Ensino e Pesquisa em Ciências da Saúde (CEP/FEPECS), para a coleta de dados foi utilizado um instrumento organizado em duas partes, sendo a primeira um questionário com perguntas relacionadas ao perfil sociodemográfico e de saúde, e a segunda parte constituída pelo roteiro 
de entrevista semiestruturado, sequenciado e elaborado de acordo com a teoria de Nola Pender (APÊNDICE 1). A coleta seguiu os seguintes passos:

Passo 1: Inicialmente, foi realizado o levantamento do quantitativo de pacientes portadores de HIV/Aids na Papuda, através do relatório de agravos fornecido pela Gerência de Saúde do Sistema Prisional (GESSP), em seguida com posse dessas informações pesquisou-se a localização e o tipo de regime de detenção dos participantes no Sistema Integrado de Administração Penitenciária (SIAPEN), obedecendo aos critérios de inclusão e exclusão. Juntamente à direção do presídio e ao chefe do Núcleo de Saúde (NUS) da PDF II, as entrevistas foram marcadas e planejadas para ocorrerem durante o mês de agosto de 2015, às segundas-feiras, no período vespertino, sendo realizadas nos dias 10, 17, 24 e 31 do referido mês.

Passo 2: Visando resguardar a privacidade dos entrevistados e manter sigilo das informações, bem como, proporcionar segurança para que pudessem expor as suas vivências, as entrevistas ocorreram nos consultórios clínicos. O pesquisador apresentou a proposta da pesquisa aos participantes, informando-os sobre o desenvolvimento e os objetivos a serem alcançados. Como todos os participantes demonstraram interesse em participar do estudo, em seguida, solicitou-se a assinatura do Termo de Consentimento Livre e Esclarecido - TCLE (APÊNDICE 2).

As entrevistas ocorreram sem nenhuma intercorrência no interior do consultório, que, por medida de segurança, ficou com a porta entreaberta, e os entrevistados com algemas para frente. Na sala permaneceram apenas o entrevistador e o entrevistado. $\mathrm{O}$ agente penitenciário que acompanhou todo o processo conservou-se do lado de fora do consultório, aguardando a finalização da entrevista, conforme regras da instituição. As questões objetivas foram registradas em impresso próprio e as questões subjetivas foram gravadas em gravador de voz móvel do pesquisador.

Uma limitação encontrada durante a coleta de dados relacionou-se ao fato de que as pessoas privadas de liberdade geralmente se expressam pouco, falando apenas o necessário em virtude do medo de se comprometerem de alguma forma. Essa atitude ocorre devido às regras de convivência no interior dos presídios relacionadas à vida e ao convívio, impostas pela segurança pública ou até mesmo pelas próprias pessoas privadas de liberdade como uma maneira de se prezar a boa convivência. 
Dessa forma, as entrevistas, em sua grande maioria, foram bastante breves e objetivas, com um tempo médio de aproximadamente 15 minutos, gerando um discurso sucinto, mas com as informações suficientes para a análise dos dados.

\subsection{PROCEDIMENTO DE ANÁLISE DOS DADOS}

Os dados obtidos por meio das entrevistas foram transcritos e o corpus das entrevistas submetidos à análise de conteúdo com auxílio do software Alceste (Analyse Lexicale par Contexte d'un Ensemble de Segments de Texte), que consiste em conjugar uma série de procedimentos estatísticos, considerando as coocorrências de palavras e expressões de um determinado texto, apontando as informações essenciais por intermédio de enunciados simples (NASCIMENTO; MENANDRO, 2006).

Este relatório também disponibilizou um dendograma apresentado em dois eixos e cinco classes, onde em cada classe as palavras de maiores coocorrências e os principais extratos das falas dos participantes receberam destaques. Dessa forma, buscou-se identificar nos resultados obtidos os aspectos significativos da promoção da saúde à luz da Teoria de Promoção da Saúde, de Nola Pender na definição das categorias.

\subsection{PROCEDIMENTOS ÉTICOS}

O presente estudo foi encaminhado ao CEP/FEPECS na data de 01/04/2015, sendo aprovado e liberado em 29/06/2015 para se iniciar a pesquisa, sob o número de Protocolo 027867/2015, conforme Parecer Consubstanciado (ANEXO 1).

Após aprovação, durante a realização da pesquisa adotaram-se os preceitos éticos vigentes na Resolução n. ${ }^{\circ}$ 466, de 12 de dezembro de 2012, do Conselho Nacional de Saúde, garantindo aos participantes envolvidos privacidade, proteção da integridade física e moral, preservação de dados e a confidencialidade pela participação na pesquisa (BRASIL, 2012).

Todos os participantes concordaram em participar voluntariamente, assinaram o Termo de Consentimento Livre e Esclarecido (TCLE), impresso em duas vias, sendo uma anexada em seu respectivo prontuário médico e a outra, sob posse do pesquisador; também foram informados sobre a investigação do estudo e assegurados do resguardo de qualquer constrangimento e/ou risco de acidentes relacionados. 


\section{RESULTADOS E DISCUSSÃO}

\subsection{PERFIL DOS PARTICIPANTES}

O perfil sociodemográfico dos 12 participantes do estudo ficou definido da seguinte forma: todos eram do sexo masculino e soropositivos; quanto ao gênero, apenas um declarou ser homossexual; a faixa etária variou entre 27 e 62 anos, com média de 37,5 anos, o que caracteriza uma população de adultos jovens; e a maioria $(66,6 \%)$ se declarou solteira, sendo dois amasiados, um divorciado e apenas um dos participantes casado, conforme dados apresentados na Tabela 1.

TABELA 1 - CARACTERIZAÇÃO DOS PARTICIPANTES QUANTO À IDADE, ORIENTAÇÃO SEXUAL E ESTADO CIVIL. BRASÍLIA, 2016

\begin{tabular}{ccccc}
\hline PARTICIPANTES & IDADE & ORIENTAÇÃO SEXUAL & ESTADO CIVIL \\
\hline Participante 1 & 38 & Heterossexual & Casado \\
Participante 2 & 40 & Heterossexual & Solteiro \\
Participante 3 & 37 & Homossexual & Solteiro \\
Participante 4 & 27 & Heterossexual & Solteiro \\
Participante 5 & 27 & Heterossexual & Solteiro \\
Participante 6 & 43 & Heterossexual & Amasiado \\
Participante 7 & 32 & Heterossexual & Solteiro \\
Participante 8 & 32 & Heterossexual & Solteiro \\
Participante 9 & 36 & Heterossexual & Amasiado \\
Participante 10 & 62 & Heterossexual & Divorciado \\
Participante 11 & 28 & Heterossexual & Solteiro \\
Participante 12 & 49 & Heterossexual & Solteiro \\
\hline
\end{tabular}

O perfil dos participantes corrobora dados do Infopen 2014 o qual indica que a maior parte da população prisional brasileira é formada por jovens adultos entre 18 e 29 anos (56\%), podendo constatar que a proporção de jovens é maior no sistema prisional que na população em geral $(21,5 \%)$. Não há diferenças significativas em relação à faixa etária da 
população prisional feminina e masculina, porém, a proporção de jovens entre a população masculina (56\%) é maior que entre a população prisional feminina (49\%). O fato de a grande maioria ser de jovens justifica também a estatística de que $57 \%$ da população prisional brasileira é solteira (BRASIL, 2014a).

Estudos com portadores de HIV/Aids em penitenciárias brasileiras assemelham-se com os resultados obtidos neste estudo. Nas penitenciárias de Mato Grosso do Sul, a média de idade das pessoas infectadas pelo HIV foi de 34 anos, tendo maior probabilidade de estarem infectadas com o HIV, pessoas solteiras, identificadas como homossexuais ou que já tiveram relações homossexuais, com histórico de DSTs (CAZANTI; ENNE; CRODA, 2014).

Coelho et al. (2007), em seu estudo desenvolvido em uma penitenciária de Ribeirão Preto com portadores de HIV/Aids, demonstrou que a faixa etária mais acometida pela infecção pelo HIV foram os pessoas privadas de liberdade maiores de 30 anos, sendo também inversamente proporcional à escolaridade, estando a infecção mais prevalente em detentos com escolaridade menor que dois anos, e ausente naqueles com escolaridade maior que 8 anos.

Em relação à escolaridade, nota-se que dois participantes se declararam analfabetos, cinco possuíam ensino fundamental incompleto, dois ensino médio incompleto e apenas três possuíam ensino médio completo. Devido a essa baixa escolaridade da população privada de liberdade, observa-se também que as profissões ou ocupações em que estavam inseridos anteriormente à prisão não possuem uma boa remuneração possibilitando uma melhor condição financeira (TABELA 2).

TABELA 2 - CARACTERIZAÇÃO DOS PARTICIPANTES QUANTO À PROFISSÃO/OCUPAÇÃO, ESCOLARIDADE, CRENÇA RELIGIOSA E ANOS DE RECLUSÃO. BRASÍLIA, 2016

\begin{tabular}{|c|c|c|c|c|}
\hline PARTICIPANTES & $\begin{array}{l}\text { PROFISSÃO/ } \\
\text { OCUPAÇÃO }\end{array}$ & ESCOLARIDADE & $\begin{array}{c}\text { CRENÇA } \\
\text { RELIGIOSA }\end{array}$ & $\begin{array}{c}\text { ANOS DE } \\
\text { RECLUSÃO }\end{array}$ \\
\hline Participante 1 & Eletrotécnico & $\begin{array}{l}\text { Ensino médio } \\
\text { incompleto }\end{array}$ & $\begin{array}{l}\text { Cristão, mas sem } \\
\text { religião }\end{array}$ & 15 \\
\hline Participante 2 & Jardineiro & $\begin{array}{l}\text { Ensino fundamental } \\
\text { incompleto }\end{array}$ & Evangélico & 8 \\
\hline Participante 3 & Cabeleireiro & Analfabeto & $\begin{array}{l}\text { Cristão, mas sem } \\
\text { religião }\end{array}$ & 6 \\
\hline Participante 4 & $\begin{array}{l}\text { Assistente de } \\
\text { mecânico }\end{array}$ & $\begin{array}{l}\text { Ensino médio } \\
\text { incompleto }\end{array}$ & $\begin{array}{l}\text { Cristão, mas sem } \\
\text { religião }\end{array}$ & 17 \\
\hline
\end{tabular}


TABELA 2 - CARACTERIZAÇÃO DOS PARTICIPANTES QUANTO À PROFISSÃO/OCUPAÇÃO, ESCOLARIDADE, CRENÇA RELIGIOSA E ANOS DE RECLUSÃO. BRASÍLIA, 2016

\begin{tabular}{|c|c|c|c|c|}
\hline PARTICIPANTES & $\begin{array}{l}\text { PROFISSÃO/ } \\
\text { OCUPAÇÃOO }\end{array}$ & ESCOLARIDADE & $\begin{array}{l}\text { CRENÇA } \\
\text { RELIGIOSA }\end{array}$ & $\begin{array}{c}\text { ANOS DE } \\
\text { RECLUSÃO }\end{array}$ \\
\hline Participante 5 & Mecânico & $\begin{array}{l}\text { Ensino fundamental } \\
\text { incompleto }\end{array}$ & Sem religião & 6,5 \\
\hline Participante 6 & $\begin{array}{c}\text { Carpinteiro, } \\
\text { pedreiro e pintor }\end{array}$ & $\begin{array}{l}\text { Ensino fundamental } \\
\text { incompleto }\end{array}$ & $\begin{array}{l}\text { Cristão, mas sem } \\
\text { religião }\end{array}$ & 44 \\
\hline Participante 7 & $\begin{array}{c}\text { Auxiliar } \\
\text { administrativo }\end{array}$ & Ensino médio & Católico & 2,5 \\
\hline Participante 8 & Motoboy & Ensino médio & Evangélico & 6 \\
\hline Participante 9 & $\begin{array}{l}\text { Agente de crédito - } \\
\text { microcrédito }\end{array}$ & Ensino médio & $\begin{array}{l}\text { Cristão, mas sem } \\
\text { religião }\end{array}$ & 21 \\
\hline Participante 10 & Aposentado & $\begin{array}{l}\text { Ensino fundamental } \\
\text { incompleto }\end{array}$ & $\begin{array}{l}\text { Cristão, mas sem } \\
\text { religião }\end{array}$ & 45 \\
\hline Participante 11 & Artesão & Analfabeto & Evangélico & 14,5 \\
\hline Participante 12 & Serviços gerais & $\begin{array}{l}\text { Ensino fundamental } \\
\text { incompleto }\end{array}$ & Católico & 22 \\
\hline
\end{tabular}

O grau de escolaridade da população prisional brasileira é extremamente baixo. Oito em cada dez pessoas presas estudaram, no máximo, até o ensino fundamental, enquanto a média nacional de pessoas que não frequentaram o ensino fundamental ou o têm incompleto é de 50\%. Em contrapartida, na população brasileira, cerca de $32 \%$ completaram o ensino médio, e apenas 8\% da população prisional o tem concluído (BRASIL, 2014a).

Dessa forma, os dados obtidos nesta pesquisa confirmam outros estudos em relação ao perfil e caracterização da população penitenciária brasileira, composta predominantemente de homens jovens, de baixa renda, que não tiveram oportunidade de completar seus estudos básicos, sem uma profissão definida anteriormente ao ingresso à prisão, evidenciando, assim, uma situação de exclusão social. Tais estudos associam os delitos praticados à condição de pobreza e às situações precárias de inserção no mercado de trabalho (BRASIL, 2004; CARTAXO et al., 2013).

Quanto à crença religiosa, um participante se declarou ateu, os demais cristãos, porém $50 \%$ não praticam nenhuma religião. Já em relação aos anos de reclusão, houve 
variação de 2,5 a 45 anos, com uma média de 17,2 anos, sendo a maioria relacionada a furtos e extorsão, homicídio e tráfico de drogas (TABELA 2).

Segundo Infopen (2014), nota-se que o tempo de pena das pessoas privadas de liberdade condenados, para os quais se obteve informação, mais da metade (53\%) dessas pessoas foram condenadas com pena de até oito anos de reclusão. Apenas 1,7\% das pessoas foi condenada a mais de cinquenta anos de prisão. No Distrito Federal, o tempo de pena de maior prevalência entre a população está entre mais de quatro até oito anos (29,2\%), seguida de mais de oito até 15 anos (25.9\%) (BRASIL, 2014a).

Outro fator que pode também estar associado ao envolvimento com o crime e as drogas, é o de que metade dos entrevistados não possui uma religião estabelecida, e, segundo Galúcio (2012), algumas vezes o contato com algum tipo de religião se dá pela primeira vez dentro do cárcere, por meio da assistência religiosa, prevista na Lei de Execução Penal - LEP n. 7.210. Essa assistência pode contribuir para o equilíbrio e redução de conflitos nos estabelecimentos penais, assim como para o processo de recuperação e ressocialização dos internos (BRASIL, 1984).

\subsection{SOBRE HIV/AIDS E A PROMOÇÃO DA SAÚDE: RELATOS DE PESSOAS PRIVADAS DE LIBERDADE}

Quanto à análise pelo software Alceste, foram identificadas no corpus 7.444 ocorrências de palavras, nas 12 entrevistas, após padronização segundo as normas estabelecidas para análise do mesmo. O programa efetuou a clivagem do corpus em 218 unidades de contexto elementares (UCEs), que são os extratos das falas dos entrevistados. Destas, 99 (45\%) foram inseridas nas cinco classes conforme demonstra dendograma abaixo, sendo o número mínimo de 11 UCEs para constituir uma classe (FIGURA 2).

$\mathrm{Na}$ análise de conteúdo das entrevistas, emergiram dois eixos significativos. O primeiro eixo, denominado "HIV/Aids no cárcere: vulnerabilidades, diagnóstico, tratamento e barreiras existentes", faz menção ao HIV/Aids e foi composto pelas categorias que dizem respeito aos comportamentos individuais anteriores à infecção, ao diagnóstico, ao tratamento e às barreiras existentes para a adoção de comportamentos de promoção da saúde na prisão. 
Esse eixo foi composto por três categorias/classes, que juntas compreendem $61 \%$ dos extratos das falas dos sujeitos (FIGURA 2).

\section{FIGURA 2 - DENDOGRAMA DO CORPUS DAS ENTREVISTAS ORGANIZADO EM DOIS EIXOS E CINCO CLASSES. BRASÍLIA, 2016}

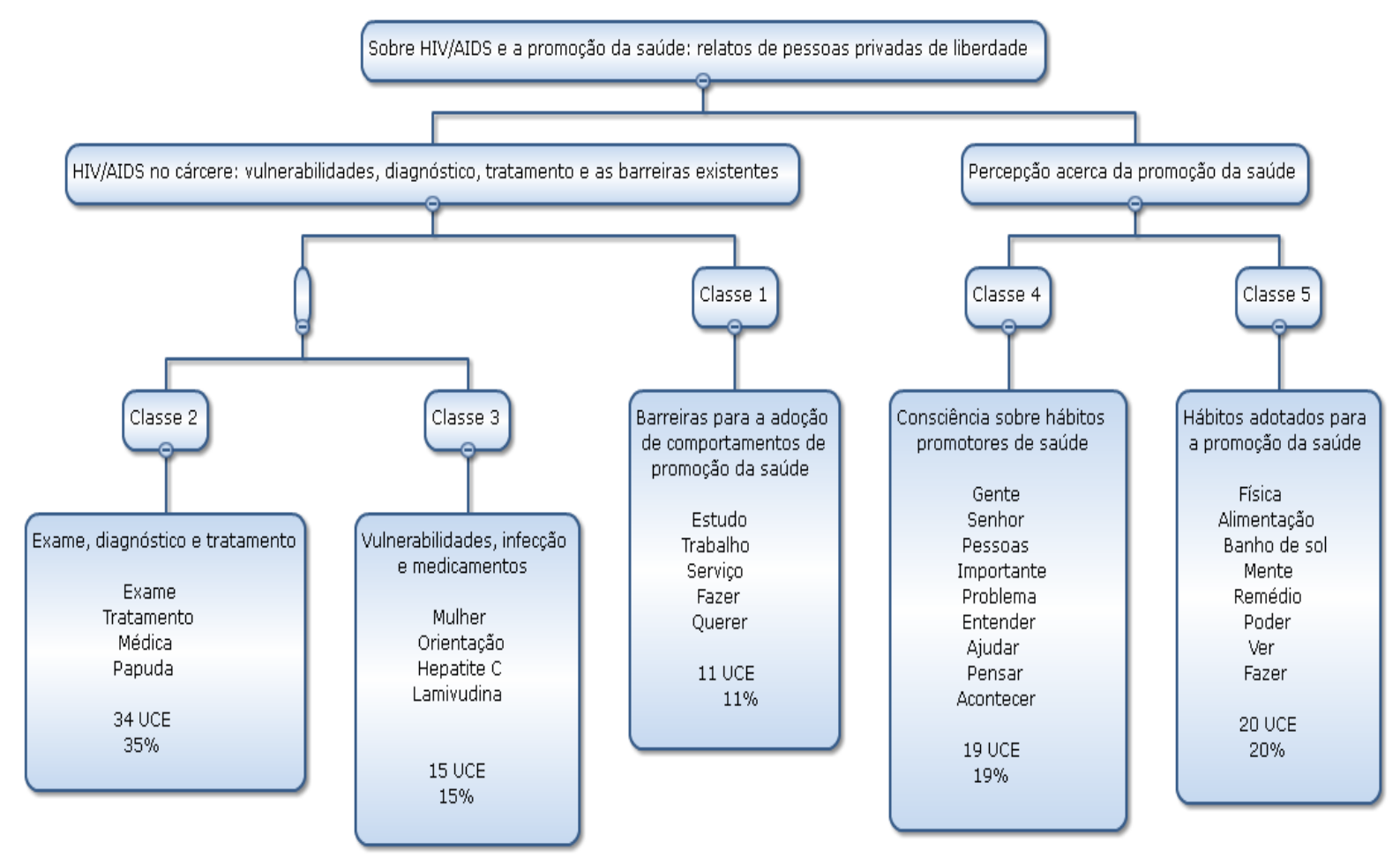

O segundo eixo foi denominado de "Percepção acerca da promoção da saúde" e faz menção à promoção da saúde, qualidade de vida e hábitos saudáveis adotados, sendo composto por duas categorias/classes, que juntas compreendem 39\% dos extratos das falas dos sujeitos (FIGURA 2).

\subsubsection{Eixo 1: HIV/Aids no cárcere: vulnerabilidades, diagnóstico, tratamento e as barreiras existentes}

Esse primeiro eixo foi formado por três classes distintas, e a classe dois, "Exame, diagnóstico e tratamento", foi a de maior significância, possuindo 36 UCEs, o que representa $35 \%$ do total de todas as UCEs originadas. Essa classe possui relação com o núcleo central da teoria de Nola Pender, uma vez que podemos considerar que a adesão ao tratamento 
compreende um comportamento de promoção da saúde, já que cientificamente traz benefícios ao paciente, melhorando seu quadro clínico, diminuindo sua morbimortalidade e, consequentemente, aumentando sua qualidade de vida (FIGURA 2).

A classe dois está diretamente relacionada à classe três, e é denominada "Vulnerabilidades, infecção e medicamentos", pois os assuntos se complementam em relação ao HIV/Aids, possuindo 15 UCEs, o que representa 15\% do total (FIGURA 2).

Ao analisar toda a unidade textual da classe três, percebe-se que sua grande maioria relacionava-se com os comportamentos de risco dos participantes que antecederam a infecção pelo HIV, estando desta forma associada diretamente à primeira fase da teoria por se tratar das características e experiências individuais anteriores dos participantes à infecção (FIGURA 2).

A classe um, "Barreiras para a adoção de comportamentos de promoção da saúde", apresentou apenas 11 UCEs, representando $11 \%$, e se enquadra também ao núcleo central da teoria por se tratar de relatos que envolvem barreiras existentes no ambiente prisional que dificultam o convívio com a doença no respectivo ambiente, influenciando diretamente na adoção de comportamentos de promoção da saúde (FIGURA 2).

\subsubsection{Classe 2: Exame, diagnóstico e tratamento}

Nessa classe as palavras de maior destaque foram exame, tratamento, médica e Papuda, o que permite dizer que o paciente, ao entrar no presídio, realizou o exame, e por meio deste obteve o diagnóstico da doença, e em seguida foi consultado pela equipe médica, que indicou e iniciou o tratamento preconizado.

O diagnóstico de HIV/Aids, apesar de toda a evolução obtida nas últimas três décadas, ainda é bastante doloroso por se tratar de uma doença estigmatizada, desvalorizada moralmente e socialmente, devido à falta de conhecimento da população sobre a mesma e o seu tratamento, e por ser um marco inicial para a construção de uma nova história e identidade. Todos esses fatores despertam sentimentos e comportamentos negativos, de transtornos e inseguranças, por representarem para essas pessoas a certeza de estarem próximo à morte (CARDOSO, MARCON, WAIDMANI, 2008; CARVALHO, GALVÃO, SILVA, 2010; MALISKA et al., 2009; MARQUES et al., 2006). 
A primeira vez que eu vim preso, eu já tinha ficado sabendo que a finada fulana e o finado sicrano, que eram os primeiros que eu tinha tomado, que eles tinham morrido, com esse problema, sabe? Então, já tinha a suspeita! Aí, eu falava, quando eu cheguei na Papuda, que nunca ia fazer esse exame, ia morrer sem saber. Mas aí eu fiz, porque eu não sabia, porque eu não entendia que o exame de sífilis era o mesmo resultado que o de $H I V(E 2)$.

[...] em 2005 eu fiz um exame aqui, eu pedi pra fazer o exame aqui no sistema penitenciário, porque eu tive relacionado com uma pessoa no estado de Goiás [...] A gente pensa que quem vê cara, não vê Aids, né? Aí, eu fiz o exame, e depois de trinta dias, constou. Eu fiquei muito chocado, assim, no tempo, sem saber se eu tinha prejudicado a minha esposa e o meu filho na época, e sem saber como dá aquela notícia pra ela; e aí, a psicóloga foi me preparando e, até que um dia, ela chamou a minha esposa ali numa sala, e aí, me tirou do pátio, e aí, foi aí que eu falei a notícia pra ela. Ela ameaçou me abandonar na hora, e depois voltou atrás, falou que me amava, que tava comigo... Fiz os exames e, graças a Deus, o que era o maior peso da minha consciência era esse: de ter contaminado ela, né. E aí, ela tava, graças a Deus, saudável... Mas, assim, no começo, eu cheguei a emagrecer dez quilos em uma semana, e aí, a minha vontade era só de morrer (E 9).

No presente estudo, o tempo de diagnóstico pela infecção variou de 1 a 20 anos, com a média de 10,6 anos, podendo perceber que 10 dos 12 participantes receberam seu diagnóstico após a prisão, evidenciando, dessa forma, o desinteresse pelo cuidado da saúde enquanto estavam em liberdade, e também a responsabilidade e compromisso dos profissionais de saúde que atuam na saúde prisional com a sua clientela.

Atualmente, no momento em que a pessoa privada de liberdade adentra ao sistema penitenciário do Distrito Federal, ela participa de um acolhimento em saúde, recebendo vacinas, orientações em saúde, agendamento de consultas, se necessário, e ainda lhe é oferecida a realização de testes rápidos ou exames laboratoriais como sorologia viral, que detecta infecção pelo HIV, sífilis, hepatite B e C. Por estarem adentrando uma nova realidade e por estarem emocionalmente abalados, muitos negam a realização desses exames, e só posteriormente terão uma nova oportunidade de realização, seja por manifestação própria ou por estar com o estado de saúde debilitado.

A ampliação do acesso ao diagnóstico de HIV/Aids é um desafio aos programas de saúde pública em todo o mundo. Testes laboratoriais convencionais são complexos, requerem profissionais especializados e infraestrutura física e de maquinários apropriadas, além de ter um prazo de entrega dos resultados prolongado, o que pode levar o indivíduo ao desinteresse pela busca do resultado (BRASIL, 2014d).

Desde 2005, a utilização dos testes rápidos permite atender à crescente demanda pelo diagnóstico de HIV/Aids e outras doenças sexualmente transmissíveis, de maneira ágil, não 
excedendo o tempo de 30 minutos. A testagem presencial é obrigatória, sendo de fácil execução, não necessitando, assim, de estrutura laboratorial, podendo ser feito por meio de amostra de sangue total obtida por punção venosa ou da polpa digital, ou com amostras de fluido oral, permitindo, dessa forma, o rápido encaminhamento para consultas especializadas e início do tratamento (BRASIL, 2014d).

Diante de todas as dificuldades existentes na revelação do diagnóstico de HIV/Aids, cabe ao profissional de enfermagem perceber e interferir ativamente sobre os aspectos evitáveis, como o adoecimento e sofrimento desnecessário, prestando informações sobre a doença, o tratamento e cuidados gerais. É de fundamental importância aproveitar todas as oportunidades cotidianas de contato para aumentar o vínculo enfermeiro-paciente, e desenvolver estratégias educativas específicas a essa nova realidade, e aos poucos essas dificuldades vão sendo substituídas por sentimentos positivos de valorização da vida e de mudanças nos comportamentos, em busca de uma melhor qualidade de vida (CARDOSO, MARCON, WAIDMANI, 2008; MALISKA et al., 2009; MARQUES et al., 2006).

Em busca de melhores resultados no manejo da síndrome, preconiza-se a priorização do acesso precoce ao diagnóstico, com a finalidade de se iniciar o tratamento em tempo oportuno, interferindo diretamente na transmissão e disseminação da doença, assim como na diminuição da morbimortalidade, e aumento da qualidade de vida (HALLAL et al, 2013).

Em relação ao tratamento antirretroviral, 11 entrevistados relataram fazer uso da medicação antirretroviral, conforme lhes foi orientado pela equipe de saúde.

Quando eu comecei a tomar, o primeiro que me atendeu foi o Doutor, aí eu perguntei pra ele o horário pra eu tomar, e ele falou assim: "Não tem um horário certo pra você, arruma um esqueminha pra você tomar". Ai, eu preferi à noite, porque assim que eu tomo eles, uns vinte minutos já me dá sono, sabe (E 2).

Tomo certinho, dez horas da noite, eu tomo o remédio (E 5).

Tomo o meu remédio depois da novela, durmo e daí, eu não acordo mais (E 3).

A gente depende de tudo dos outros, em termos de medicamento, de tratamento, de fazer exame [...] mas, pelo menos, é certinho esses negócio assim, eu pego o meu medicamento todo dia 12, então, dia 12 sempre a Enfermeira me tira (E 6).

A não adesão ao tratamento foi mencionada apenas por dois dos entrevistados no início do tratamento, mas atualmente os mesmos relatam seguir o tratamento proposto. 
Porque eu acredito muito na Enfermeira e no Doutor, que já faz o acompanhamento comigo já tem mais de treze anos. Mas, eu não tomava não, de primeira, fui tomar tem pouco tempo (E 6).

Quando eu descobri, no começo, eu não usava, né... Aí foi depois que eles começaram a me dar porque explodiu em mim a herpes zóster, né... Aí, o Doutor falou que eu ia ter que usar porque era um problema de saúde (E 12).

Santos, W. et al. (2011) realizou um estudo com 26 pacientes portadores de HIV/Aids em uso de antirretrovirais, sendo 13 aderentes ao tratamento e 13 não aderentes; como barreiras à adesão, os pacientes associaram a sensação de prisão ao tratamento devido aos rígidos horários e necessidade de mudança no estilo de vida, dificuldades financeiras para se deslocaram com frequência aos ambulatórios para fazerem consultas, exames e a retirada da medicação, o uso do álcool, efeitos colaterais da medicação e a quantidade de medicamentos a serem ingeridos. Já aspectos facilitadores à terapia relacionaram-se à ausência de efeitos colaterais, memórias relacionadas com os sintomas de doenças oportunistas adquiridas anteriormente, ou até mesmo da Aids, a descoberta do aumento da sobrevida e da melhoria na qualidade de vida com o uso da terapia e o bom relacionamento com membros da rede social.

As dificuldades de acesso ao tratamento, levando à não retirada da medicação nas farmácias de dispensação de antirretrovirais, foram dados encontrados nos estudos de Dantas et al. (2012); Santos, W. et al. (2011); Romeu et al. (2012); e Santos, Seidl (2011). Porém, esse fato não é uma realidade existente na população privada de liberdade do Complexo Penitenciário da Papuda, uma vez que essa população recebe a medicação mensalmente pelos profissionais de saúde que ali atuam, sendo estes os responsáveis pela retirada da medicação nas farmácias de dispensação do programa de DST/HIV/Aids. Assim, a avaliação da adesão pelo paciente nesses locais ocorre por meio do autorrelato e pela análise dos exames laboratoriais que são realizados semestralmente ou sempre que necessário.

A qualidade das informações repassadas aos pacientes em relação à doença e ao tratamento interfere diretamente na adesão, assim como condições sociodemográficas relacionadas à idade, escolaridade, renda, uso de drogas lícitas e ilícitas estão associadas à dificuldade de compreensão em relação à doença, medicação, dosagem, horário, reações adversas e retorno às consultas (FAGUNDES et al., 2010).

A grande maioria dos participantes desta pesquisa, como se pôde perceber nos extratos das falas citados anteriormente, demonstraram terem um bom vínculo com a equipe 
de saúde, principalmente com o médico infectologista e a enfermeira, demonstrando respeito, confiança e admiração por ambos, o que é algo positivo em relação à adesão ao tratamento.

O vínculo e a boa relação com os profissionais de saúde são fatores que fortalecem a adesão ao tratamento, uma vez que nem sempre todos os pacientes possuem apoio familiar ou do ciclo social a que pertencem (ROMEU et al., 2012); e esse apoio é imprescindível, principalmente no início da doença, sendo de primordial importância para ajudar os pacientes no enfrentamento do problema e no tratamento, já que o diagnóstico do HIV/Aids é algo assustador e desmotivador para se continuar a viver (SANTOS, W. et al. 2011).

Romeu et al. (2012) pôde perceber em seu estudo que, apesar de apoio familiar estar presente na maioria dos casos, $94,9 \%$ dos sujeitos afirmaram também terem uma boa relação com o infectologista que os acompanham; já Santos, W. et al. (2011) também constataram que pacientes não aderentes ao tratamento relataram possuir baixo vínculo social.

Doenças oportunistas durante o cumprimento da pena foram relatadas por seis entrevistados (50\%), e dentre elas houve a ocorrência de pneumonia em três, tuberculose em dois, herpes zóster e infecção urinária em apenas um participante cada.

Tuberculose, essa ganglionar, não foi a respiratória não (E 2).

Pneumonia, só isso mesmo, pneumonia, mas me tratei (E 6).

Estudo realizado por Fagundes et al. (2010), relacionado com infecções oportunistas de pacientes portadores do HIV/Aids e o uso de antirretrovirais, concluiu que, dos 144 pacientes avaliados, 131 apresentaram alguma infecção oportunista antes de iniciar o tratamento antirretroviral, e, após a introdução da terapia antirretroviral, doenças oportunistas foram relatados em 74 pacientes, o que representa uma queda de $81 \%$. Dos pacientes que mesmo em uso de antirretrovirais apresentaram infecção(ões) oportunista(s), 58 alegaram uso irregular de antirretrovirais e 16 uso regular, podendo evidenciar que o uso regular da terapia antirretroviral está diretamente ligado à diminuição da ocorrência das doenças oportunistas.

Nesse mesmo estudo, as doenças oportunistas mais prevalentes antes de se iniciar o tratamento foram respectivamente diarreias, candidíase oral, herpes cutâneo, pneumocistose, toxoplasmose e tuberculose pulmonar. Após a introdução da terapia antirretroviral, apesar da grande diminuição, as mais prevalentes respectivamente foram herpes cutâneo, candidíase 
oral, diarreias, pneumocistose, toxoplasmose e tuberculose pulmonar (FAGUNDES et al., 2010).

5.2.1.2 Classe 3 - Vulnerabilidades, infecção e medicamentos.

As palavras mulher, orientação, hepatite $\mathrm{C}$ e lamivudina nos permite relacionar essa classe com as vulnerabilidades individuais dos participantes, como o relacionamento sexual com mulheres, presença de DST, além de representar também as orientações que eles recebem em relação à medicação utilizada.

Nas últimas décadas, as políticas públicas relacionadas com o HIV/Aids adotaram o conceito de vulnerabilidade, em substituição aos conceitos de grupos de risco e/ou comportamentos de risco, para conscientizar a população, em um âmbito geral, sobre as formas de prevenção, com o intuito de diminuir ou acabar com as ideias rotuladoras de preconceito, isolamento e estigmatização relacionadas à doença (MAIA, GUILHEM, FREITAS, 2008; SOUSA, MIRANDA, FRANCO, 2011).

A Aids é uma doença que coloca em destaque a sexualidade e os sentimentos de culpa e castigo, em que as vulnerabilidades estão relacionadas às situações adversas da vida, variando de acordo com os indivíduos ou o coletivo, regiões, grupos sociais, situação econômica e nível educacional (SOUSA; MIRANDA; FRANCO, 2011).

A epidemia da doença no Brasil é bem caracterizada no Boletim Epidemiológico HIV/Aids (2015), em que a maioria dos casos novos se concentram em populações vulneráveis, como gays e homens que fazem sexo com homens, travestis e transexuais, usuários de drogas e profissionais do sexo (BRASIL, 2015a). Em estudos realizados por Maia, Guilhem, Freitas (2008) e Garcia, Souza (2010), identificaram-se maiores vulnerabilidades em pessoas com menor condição socioeconômica e menor alfabetização, pelo fato de se obter dificuldades no acesso à informação ou até mesmo na tomada de decisão.

Estudo realizado por Guerriero, Ayres, Hearst (2002) e Marques Junior, Gomes, Nascimento (2012), associado à masculinidade e vulnerabilidades ao HIV, evidenciou que as concepções de masculinidade relacionadas à força, coragem, virilidade, impetuosidade e dominação levam a adoção de comportamentos de risco, como o sexo desprotegido e com múltiplas parceiras, tornando-os, dessa forma, mais suscetíveis à infecção pelo HIV. 
As vulnerabilidades relacionadas à infecção do HIV/Aids, como sexo desprotegido, múltiplos parceiros, uso de drogas, histórico de DSTs, caracterizam bem os participantes desta pesquisa, conforme demonstra a Tabela 3.

TABELA 3 - VULNERABILIDADES INDIVIDUAIS ANTERIORES À INFECÇÃO DO HIV/AIDS. BRASÍLIA, 2016

\begin{tabular}{|c|c|c|c|}
\hline $\begin{array}{c}\text { PRÁTICAS } \\
\text { COMPORTAMENTAIS } \\
\text { ANTERIORES }\end{array}$ & FATORES INDIVIDUAIS & $\begin{array}{l}\text { FREQUÊNCIA } \\
\quad(\mathrm{N}=12)\end{array}$ & $\%$ \\
\hline \multirow[b]{2}{*}{ Relações sexuais } & Sexo sem preservativo & 12 & $100 \%$ \\
\hline & Múltiplas parceiras & 9 & $75 \%$ \\
\hline \multirow{7}{*}{ DSTs } & Gonorreia & 2 & \\
\hline & Sífilis & 2 & \\
\hline & Condiloma acuminado & 3 & \\
\hline & Hepatite C & 3 & \\
\hline & Cancro Mole & 1 & \\
\hline & Sim, não especificada & 4 & $77 \%$ \\
\hline & Não & 1 & \\
\hline \multirow{5}{*}{ Drogas } & Maconha & 9 & \multirow{5}{*}{$83 \%$} \\
\hline & Cocaína & 7 & \\
\hline & Crack & 1 & \\
\hline & Cocaína injetável & 3 & \\
\hline & Não & 2 & \\
\hline
\end{tabular}

Os participantes da pesquisa relataram que os seus comportamentos anteriores à infecção pelo HIV incluía comportamento de risco, pois não usavam preservativo em relações sexuais, $100 \%$ dos entrevistados não tinha o hábito dessa prática; muitos deles (75\%), além de não usarem o preservativo, ainda relataram relações sexuais com múltiplas parceiras, tornando-os ainda mais suscetíveis à infecção.

Eu era muito novo. Eu era um travesti bonito e... e camisinha era... era lenda. Nunca usei preservativo com meu parceiro (E 3).

É, cavalo doido, sem preservativo [...] Rapaz, eu tenho uma suspeita que foi de uma mulher que eu ficava com ela lá no Pedregal, no Goiás. Mas não tenho a certeza não, porque ela era banda, e aí, eu tenho ela na minha mente (E 4).

Eu tinha várias parceiras, separei da minha ex-mulher e conheci essa menina aí. Eu acho que ela era mulher de programa, eu acho. E preservativo, não usava (E 5). 
O comportamento dos entrevistados corrobora os estudos que afirmam que o preservativo constitui a principal barreira contra a infecção por DSTs, incluindo o HIV/Aids; entretanto, é pouco utilizado, e quando utilizado o intuito é evitar uma gravidez indesejada e não prevenir doenças (GUERRIERO, AYRES, HEARST, 2002; MARQUES JUNIOR, GOMES, NASCIMENTO, 2012).

O uso de preservativo não é um hábito frequente por ser um produto de alto custo, de difícil colocação, podendo levar à perda da ereção e, por diminuir a sensibilidade tanto do homem quanto da mulher, deixando a relação menos prazerosa, dessa forma, a preocupação com o uso do preservativo é deixada para as parceiras, uma vez que, no imaginário masculino, a preocupação com a saúde e prevenção de doenças é uma demonstração de fraqueza (GUERRIERO; AYRES; HEARST, 2002).

Em um estudo realizado com 109 portadores do HIV/Aids, evidenciou-se que 90,8\% dos destes não faziam uso de preservativo nas relações sexuais antes de serem infectados pelo vírus; mas, após a descoberta da soropositividade, passaram a utilizar esse método de proteção em suas relações sexuais. Os motivos para não utilização do preservativo em suas relações sexuais anteriores à infecção estavam relacionados à falta do preservativo no momento da relação, à confiança no parceiro e à falta de conhecimento sobre a doença associada à necessidade de usar proteção (LIMA; FREITAS, 2012).

Além desse fator de risco, também foi possível apreender o hábito de manter relações com múltiplas parceiras. O comportamento monogâmico implicaria em colocar a sua masculinidade à prova; considerando que o homem tem uma sexualidade mais aflorada e desenfreada, recusar qualquer relação sexual seria prova de pouca masculinidade (GUERRIERO, AYRES, HEARST, 2002; MARQUES JUNIOR, GOMES, NASCIMENTO, 2012).

Neste estudo, ficou evidenciado um histórico de múltiplas parceiras anterior à infecção pelo vírus, já que nove dos 12 participantes relataram essa prática; no entanto, Petrola et al. (2011) concluíram que, após a prisão, a rotatividade de parceiros não é tão grande quanto se imagina, uma vez que a maioria $(77,3 \%)$ dos entrevistados tiveram apenas um ou nenhum parceiro em seis meses.

Esse fato se dá provavelmente pelas normas e exigências das penitenciárias em relação às visitas íntimas por meio da comprovação de união estável, o que torna um fator dificultador para se manter relações sexuais no local. Mediante a não permissão destas, a 
pessoa privada de liberdade é imposta à abstinência sexual, uma vez que a existência de relações homossexuais dentro das penitenciárias é negada (REIS, BERNARDES, 2011).

As infecções sexualmente transmissíveis são causadas por mais de 30 tipos diferentes de bactérias, vírus e parasitas, e são transmitidas principalmente pelo contato sexual. Podem levar a doenças crônicas, complicações na gravidez, infertilidade, câncer e até à morte, sendo, nos países em desenvolvimento, uma das cinco principais razões pela procura aos serviços de saúde pela população adulta (WORLD HEALTH ORGANIZATION, 2008).

A ocorrência de doenças sexualmente transmissíveis anterior à infecção pelo HIV foi relatada pela maioria dos entrevistados, sendo que alguns foram infectados por mais de uma DST. Três sujeitos relataram casos de hepatite C, três de condiloma acuminado, dois de sífilis, dois de gonorreia e um de cancro mole; quatro relataram não terem tido outras DSTs, e um refere ter tido, porém não soube informar o nome no momento (TABELA 3).

[...] Me passou gonorreia, e aí, eu fui no posto. E eu descobri assim, gonorreia, sífilis e condiloma. Condiloma é as verrugas e pra essa gonorreia, eu tomei dose única (E 5).

Fiz outros exames de Hepatite C, constou que tinha, mas não sei como é que tá hoje (E 6).

Tenho, Hepatite C (E 12).

Mais de um milhão de DSTs são adquiridas a cada dia em todo o mundo, afetando principalmente e desproporcionalmente mulheres e adolescentes. Estima-se que anualmente há 357 milhões de novas infecções, sendo uma em cada quatro diagnosticadas por clamídia, gonorreia, sífilis e tricomoníase; mais de 290 milhões de mulheres possuem papiloma vírus humano (HPV), estando este relacionado com o câncer de colo de útero, o segundo câncer mais comum em mulheres, com aproximadamente 500 mil novos casos e 250 mil mortes por ano (WORLD HEALTH ORGANIZATION, 2015).

No Brasil, estudo publicado pelo Ministério da Saúde, em 2008, demonstrou que as pessoas que procuraram atendimento em clínicas relacionadas à DST/Aids apresentaram alta prevalência dessas infecções, sendo 14,4\% relacionados com as infecções bacterianas e 41,9\% com as infecções virais. A infecção pelo HPV é bastante considerável, afetando fundamentalmente os adolescentes e jovens, sugerindo que a infecção surge nas idades mais 
precoces, geralmente no início da prática sexual; taxas por infecção gonocócica e por clamídia também foram observadas com maior prevalência nas pessoas mais jovens (BRASIL, 2015d).

Pedrosa et al. (2011), ao realizarem estudo em uma unidade sentinela para DST em Manaus, durante o período de 2005 a 2008, constatou que, dos 14.338 atendimentos no local, $9.346(65,2 \%)$ foram diagnosticados com pelo menos uma DST, tendo maior predomínio em pessoas do sexo masculino, de pele parda e com média de idade de 24 anos. Em relação à prevalência das DSTs, as infecções virais representaram 73\% dos casos, e entre as doenças, o condiloma acuminado (HPV) foi a mais frequente, representando 24,6\% dos diagnósticos, seguido de herpes genital $(8,7 \%)$, gonorreia $(6,7 \%)$, tricomoníase vaginal $(2,9 \%)$, sífilis $(3,1 \%)$, infeccção por HIV $(1,5 \%)$, cancro mole $(0,6 \%)$; outras DSTs, como linfogranuloma venéreo e donovanose, não tiveram impacto no estudo.

Um fator bastante preocupante, referente a ocorrências de DSTs em pessoas privadas de liberdade, relaciona-se com o modo de vida dessa população, a luta pelo poder, a violência e a carência sexual, somadas à alta prevalência das infecções nesse grupo, favorecem a disseminação dessas doenças no local e na comunidade em geral (PETROLA et al., 2011), pois, mesmo durante o cárcere, muitos presidiários possuem relações sexuais com suas esposas e namoradas por meio das visitas íntimas, ou até mesmo com garotas de programas, que de maneira ilícita frequentam esses locais.

Sabendo que a ocorrência de algumas DSTs pode potencializar em três vezes ou mais a chance de infectar-se pelo HIV (GUERRIERO, AYRES, HEARST, 2002; WORLD HEALTH ORGANIZATION, 2015), e que o tempo de reclusão está diretamente associado à predisposição da infecção por DSTs e pelo HIV - ou seja, quanto maior o tempo de detenção, maior a sua suscetibilidade às doenças causadas por via sexual (PETROLA et al., 2011) -, a situação dessas infecções torna-se ainda mais preocupante em relação à população privada de liberdade, ficando evidenciada a magnitude do problema; e neste estudo, os anos de reclusão dos participantes foi relativamente longo se comparado com o da população prisional do país.

A hepatite C é uma DST que também constitui um problema de saúde pública mundial, e está diretamente relacionada com transmissão por via parenteral, por meio de material contaminado por sangue, considerando a população prisional de alto risco para transmissibilidade em relação à população em geral.

Estudos como o de Rosa et al. (2012), em populações carcerárias no Brasil, demonstram uma alta prevalência de infecção por hepatite C nessa população $(9,7 \%)$, e 
destes, 38,9\% relataram fazer uso de drogas injetáveis e 13,8\% possuírem tatuagens. Estudos semelhantes com essa população demonstraram prevalência para infecção de hepatite $\mathrm{C}$ de 3,1\% (SANTOS; SANTANA; FRANCA, 2011), 8,7\% (COELHO et al., 2007), 8,5\% (BRITO et al., 2007), 14,8\% (GONÇALVES, 2005); como fatores associados, pesquisaram o uso de drogas injetáveis e a presença de tatuagens na população infectada, representando, respectivamente, 20,6\% e 46,2\% (SANTOS; SANTANA; FRANCA, 2011), 8,5\% e 19,2\% (COELHO, et al., 2007), 17,1\% e 13,3\% (BRITO et al., 2007), e 37,5\% e 80\% (GONÇALVES, 2005).

Assim, evidencia-se que o uso de drogas está diretamente relacionado com a infecção pelo HIV e outras DSTs, podendo ocorrer por infecção direta por meio do compartilhamento de seringas e agulhas na utilização parenteral, ou até mesmo pelo uso de cachimbos e canudos, pela possibilidade de lesões da mucosa nasal/oral. Como forma indireta por usuários de drogas, o risco relaciona-se com as alterações da libido, aumentando o desejo sexual, o que leva a relações sexuais inseguras (GIACOMOZZI, 2011; SILVA, R. et al., 2015).

No presente estudo, o uso de drogas foi bastante frequente na população, fato este que possivelmente foi um determinante na infecção pelo HIV/Aids. Dos 12 entrevistados, dez relataram uso de drogas ilícitas (83\%), sendo que, destes, três fizeram uso de drogas injetáveis. Maconha e cocaína foram as drogas mais citadas entre os mesmos, e o álcool não foi atribuído como droga por eles (TABELA 3).

Pôde-se perceber que, em relação à fonte de infecção, nove entrevistados afirmam ter sido por meio de relações sexuais sem uso de preservativo, um por uso de drogas injetáveis, e dois não souberam informar, porém estes relataram uso de drogas e terem mantido relações sexuais com múltiplas parceiras sem preservativos.

Esse fenômeno pode ser considerado pelo fato da mudança na disponibilidade das drogas ilícitas e pelas atuais políticas relacionadas ao tema vigente; no entanto, essa redução do uso de drogas injetáveis pode variar de acordo com a localização geográfica, condições econômicas e culturais (CAMARGO et al., 2012).

Dessa forma, este estudo corrobora com estudos desenvolvido por Strazza et al. (2007), desenvolvido em uma penitenciária feminina, e por Cazanti, Enne, Croda (2014), desenvolvido em penitenciárias do Mato Grosso do Sul, pois as vulnerabilidades relacionadas aos comportamentos sexuais, como sexo sem o uso do preservativo e múltiplas parceiras, tiveram maior impacto na infecção pelo HIV de soropositivos do que pelo uso de drogas. 
Em relação à medicação utilizada para o tratamento do HIV/Aids, nota-se que, apesar de essa população receber orientações pela equipe de saúde, a grande maioria não sabia informar o nome das medicações que faz uso, mas a reconhece de alguma forma; dados também encontrados no estudo de Dantas et al. (2012), nos quais o reconhecimento da medicação em uso pelos participantes foi associado à cor por $30 \%$, tamanho $30 \%$ e forma $20 \%$.

Uso. Eu sei que é cinco comprimidos, mas, agora diminuiu pra três, que é... em um vem incluído dois comprimidos, ou é três comprimidos (E 1).

Uso certinho. Eu não sei o nome delas porque eu sou analfabeto, eu não sei ler, mas eu conheço elas (E 3).

Uso, tô tomando a nova que saiu agora. Um comprimido que são quatro em um, eu tenho só um lá no vidro lá, mas de cor, eu não sei o nome, não (E 6).

Uso. Lamivudina, Efavirenz e o outro é o branquinho (E 12).

Além desses motivos, os entrevistados relataram também fazerem o uso da medicação corretamente, seguindo orientações da equipe de saúde, para poderem viver mais e com melhor qualidade de vida, conforme pode se observar abaixo.

Porque é uma maneira que eu tenho de viver mais. Tudo que eles me orientam a fazer, eu faço (E 3).

[...] eles me passam a orientação e eu tenho que acatar porque é pra minha saúde. Se eu tomar fora do pedido que eles estão me pedindo pra mim tomar, eu tô deixando a minha saúde em vão, né (E 8).

O participante que não faz uso de antirretrovirais relatou que não o faz porque se enquadra em um grupo raro de portadores que não desenvolvem a doença, permanecendo com carga viral indetectável e linfócitos T CD4+ satisfatórios, mesmo sem o tratamento.

Não uso, porque o Doutor fala que o meu caso é raro. Eles me falam que o vírus não se multiplica, a carga viral é 0,1 alguma coisa... que de mil, eu sou um (E 4).

Existe um pequeno grupo da população infectada pelo HIV, cerca de $1 \%$, que é geneticamente imune à Aids, ou seja, mesmo infectados, eles não desenvolvem a doença, vivendo normalmente sem tomar qualquer tipo de medicação. Esse fato ocorre devido a um 
defeito genético, em que essas pessoas não possuem um receptor de quimiosina denominado CCR-5, que funciona como um mensageiro celular; sem esse receptor, o vírus da Aids não consegue entrar nas células, infectá-las e se reproduzirem (BRASIL, 2005).

Estima-se que entre $15 \%$ e $20 \%$ da população tenha esse tipo de deficiência genética que leva à defesa contra a Aids. Porém, essa é uma herança genética caucasiana, não sendo encontrada nas populações negra, indiana ou asiática. Pesquisadores acreditam também que há uma relação dessa deficiência na proteção quanto à cólera, varíola e peste bubônica durante a Idade Média, encarando tal mutação como mais uma chance de encontrar a cura da Aids, ou pelo menos uma forma de impedir a transmissão da doença (BRASIL, 2005).

5.2.1.3 Classe 1 - Barreiras para a adoção de comportamentos de promoção da saúde

Nesta classe, recebem destaque os verbos fazer e querer, além de palavras como estudo, trabalho e serviço, que expressam desejos dos entrevistados em relação à promoção da dignidade humana - já que o trabalho e o serviço são direitos assegurados a essa população -, e também às barreiras e dificuldades encontradas por eles no dia a dia na penitenciária, interferindo diretamente nos comportamentos de promoção da saúde.

A superlotação é um grave problema do sistema penitenciário brasileiro, e que fere os preceitos da dignidade humana. O Complexo Penitenciário do Distrito Federal abriga $140 \%$ a mais de pessoas privadas de liberdade do que a sua capacidade, e essa superlotação interfere diretamente na rotina diária da penitenciária, pois dificulta a realização das atividades previstas, ocasionando descaso e má organização (DISTRITO FEDERAL, 2016a).

A superlotação impede que as pessoas privadas de liberdade possuam condições mínimas de higiene e conforto, devido ao calor insuportável, falta de ventilação e falta de privacidade, aumentando a ocorrência de doenças, sujeira e estresse. Essas condições degradantes aumentam as tensões no local, podendo ocasionar uma revolta devido ao sentimento de injustiça, levando esta população a cometerem atos violentos e desumanos, rebeliões, motins e tentativa de fuga (SILVA, 2014; SILVA, 2013).

A ociosidade ocasionada pela falta de um trabalho ou de estudos para ocupar o tempo e esquecer um pouco da doença e do ambiente em que vivem foi uma barreira relatada pela maioria dos participantes. 
Alguma coisa pra pessoa se ocupar a mente: trabalho, ler, alguma coisa assim, que faça a pessoa esquecer, se ocupar naquele negócio que tá fazendo (E 1).

Trabalhando, assim, a pessoa se distrai né, se distrai. Aqui eu tô muito parado, tô estudando e tudo, mas é pouco né (E 2).

Um serviço, um colégio pra você estudar, um curso pra você fazer alguma coisa. Seria bom [...] O que eu queria mais era terminar os meus estudos, pelos menos aprender a ler e escrever o meu nome certo (E 3).

Segundo a Lei de Execução Penal, é dever do Estado fornecer à pessoa privada de liberdade assistência educacional, com o objetivo de prevenir o crime e orientar o retorno à convivência em sociedade, assim como o trabalho com a finalidade educativa e produtiva (BRASIL, 1984). Porém, segundo dados do Infopen (2014), atualmente apenas uma a cada dez pessoas privadas de liberdade realizam alguma atividade educacional no país, enquanto que, no Distrito Federal, apenas 13,7\% da população prisional possuem acesso aos estudos. Em relação às atividades laborais, apenas $16 \%$ da população prisional do país trabalham, enquanto que no Distrito Federal $17 \%$ das pessoas privadas de liberdade possuem algum tipo de atividade laborativa (BRASIL, 2014a).

Dessa forma, como a maioria das pessoas privadas de liberdade é proveniente de uma classe social mais baixa e possui pouca instrução educacional, é necessário um maior investimento na educação dos reclusos, bem como maiores oportunidades de trabalho, pois, assim, se evitaria a ociosidade, o pensamento excessivo e nocivo, conseguindo então, por esses meios, reeducar as pessoas privadas de liberdade e as reintegrarem à sociedade (SILVA, 2014).

Outra queixa em relação às barreiras para se adotarem os comportamentos de promoção da saúde, foi em relação ao banho de sol, pois, segundo relatos, este possui um tempo muito curto ou até mesmo deixa de ocorrer com frequência no local. É durante esse momento que a massa carcerária consegue fazer alguma atividade física ao ar livre, socializarse com as demais pessoas, fortalecer vínculos de amizade e se distrair de alguma maneira.

O exercício que a gente tem aqui, ele é limitado, limitado. O banho de sol também, ele é um tempo limitado (E 3).

Tenho vontade de fazer atividade física, que era o que eu fazia antes (E 5). 
A Lei de Execuções Penais n. ${ }^{\circ}$ 7.210, de 11 de julho de 1984, dispõe, em seu inciso IV, artigo 52, o direito à saída da cela por duas horas diárias para banho de sol; e, ainda, em seu artigo 83, dispõe que os estabelecimentos penais, conforme a sua natureza, deverão contar em suas dependências com áreas e serviços destinados a dar assistência, educação, trabalho, recreação e prática esportiva (BRASIL, 1984).

Nos últimos tempos, vários são os estudos que associam doenças crônicas, inclusive a Aids, com a hipovitaminose $\mathrm{D}$, e sabemos que a exposição solar em horários adequados e de maneira controlada propiciam a síntese de tal vitamina no organismo, que age diretamente na manutenção do cálcio e da massa óssea.

Maria (2015), em seu estudo com pacientes em uso de antirretroviral contendo a medicação tenofovir, concluiu que a vitamina D sérica apresentou valores abaixo da normalidade na maioria dos participantes, sendo de $31 \%$ em usuários da medicação tenofovir e $20 \%$ em não usuários de tenofovir. Já em estudo desenvolvido por Sales (2014), dos 98 pacientes estudados, portadores de HIV/Aids em uso de antirretrovirais, pode-se constatar que $66 \%$ das mulheres e $72 \%$ dos homens apresentaram níveis séricos insuficientes de vitamina D, totalizando mais de $84 \%$ da amostra total.

As causas mais prováveis em relação a esse fato relaciona-se com os tradicionais fatores de risco para hipovitaminose $\mathrm{D}$, como a não ingestão de alimentos ricos em vitamina D (MARIA, 2015; SALES, 2014), a falta de exposição solar (SALES, 2014), o uso de filtro solar (CANUTO et al., 2015), uso de antirretrovirais (CANUTO et al., 2015; MARIA, 2015; SALES, 2014) e presença de sobrepeso e obesidade (CANUTO et al., 2015).

Além de benefícios para os indivíduos no geral, a atividade física pode também, dentro de estabelecimentos penitenciários, se tornar um instrumento transformador do cotidiano, objetivando o bem-estar e a qualidade de vida do detento, sendo considerada como colaboradora na ressocialização das pessoas privadas de liberdade, uma vez que sua prática é prazerosa, possui regras, exige disciplina e adequação às mais diversas normas (MORAES; MORAES; RAMOS, 2014).

Varella (2009) reafirma essa realidade em sua obra, ao salientar que o envolvimento frequente dos detentos do pavilhão sete nas práticas esportivas levou a considerá-lo como o pavilhão mais tranquilo do Presídio do Carandiru.

Porém, segundo estudo desenvolvido por Ferretti e Knijnik (2009), ao entrevistarem três ex-presidiários, pode-se concluir que a maneira como a prática esportiva e as atividades 
físicas estão sendo desenvolvidas nas penitenciárias, ao invés de reeducar as pessoas privadas de liberdade, refletem os valores do ambiente em que estão inseridos - uma vez que como não há na maioria das penitenciárias um profissional liderando essas práticas e sim outro preso -, o intuito então passa a ser ganhar dinheiro por meio de premiações, apostas e disputas por drogas.

Sabe-se que o portador de HIV/Aids necessita de cuidados em vários aspectos, inclusive na alimentação e nutrição, para promover a recuperação e manutenção de uma vida saudável. A alimentação inadequada ou insuficiente foi outra queixa apresentada por alguns sujeitos desta pesquisa, mesmo estes recebendo uma alimentação diferenciada devido ao estado de saúde em que se encontram.

\footnotetext{
A alimentação aqui não é tão bom porque a cantina não tem praticamente nada ... $e$ é muito pouco as coisas que entram da rua. Então, assim, na medida do possível o que tem é o que o sistema penitenciário oferece - que é quase nada -, aí, a gente vai se alimentando do jeito que dá, né (E 9).

Condições para uma alimentação melhor, né (E 1).
}

Portadores de HIV/Aids, diabéticos, hipertensos, obesos, desnutridos, pacientes com tuberculose ou outras infecções respiratórias, pacientes em tratamento de hepatite $\mathrm{C}$, cadeirantes e outros casos excepcionais, necessitam de uma dieta diferenciada, rica em alguns nutrientes. Dessa forma, após avaliação do médico ou enfermeiro, geralmente essas dietas são alteradas de acordo com a necessidade individual, podendo ser complementadas com mais frutas, carnes, leite, feijão e outros. Porém, dentro do ambiente prisional, receber uma "dieta" é um privilégio de poucos, e infelizmente sabe-se que esses adicionais, mesmo devido à necessidade, podem virar moeda de troca, principalmente por drogas e cigarros.

Por meio de um estudo desenvolvido no Presídio Central de Porto Alegre - RS por Rudnicki (2011), onde a alimentação era preparada por uma equipe de detentos, pôde-se perceber que as pessoas privadas de liberdade gostavam da comida recebida e não reclamavam de questões relativas à higiene e qualidade, mas sim em relação à quantidade; e que as reclamações ocorridas a respeito eram provenientes de visitantes, advogados e juízes, que representam outra classe social, possuindo assim outros gostos e costumes em relação à alimentação. 
Já outro estudo desenvolvido no Centro de Detenção e Ressocialização do Paraná, com o intuito de se avaliar as condições higiênico-sanitárias e os aspectos nutricionais da alimentação servida, concluiu-se que a alimentação possui uma boa qualidade, uma vez que não foram detectados coliformes fecais e salmonela; porém, quanto aos aspectos nutricionais, percebeu-se que as dietas estavam com peso acima do valor permitido, sendo mais da metade do peso da marmita constituído pelo arroz branco (MASSAROLLO et al., 2012).

Apesar de nenhum participante ter feito referência a esse fato no momento da entrevista, uma queixa muito comum pelos custodiados no geral é a composição da marmita, uma vez que dizem vir com grande quantidade de arroz, pouca proteína e vegetais. O feijão, segundo eles, é algo raro e na maioria das vezes só recebem aos finais de semana.

Dessa forma, observa-se que, mesmo com a necessidade de uma dieta equilibrada e de ter legislações vigentes acerca do assunto, o sistema prisional brasileiro foge à legislação, pois oferece péssimas condições de higiene, instalações precárias e alimentação muita vezes imprópria para o consumo (SENA; FREITAS; PONTES, 2014).

\subsubsection{Eixo 2: Percepções acerca da promoção da saúde}

Este segundo eixo é formado por duas classes distintas. A classe quatro, denominada "Consciência sobre os hábitos promotores de saúde", foi composta por 19 UCEs, o que compreende $19 \%$ das UCEs totais, e refere-se aos pensamentos dos participantes em relação aos comportamentos de promoção da saúde (FIGURA 2).

A classe cinco, "Hábitos adotados para a promoção da saúde", complementa o que já foi exposto na classe anterior, reafirmando os benefícios que esses entrevistados percebem com os comportamentos de promoção da saúde adotados. É composta por 20 UCEs, o que representa $20 \%$ do total (FIGURA 2).

Essas duas classes relacionam-se também com eixos do núcleo central da Teoria de Nola Pender, uma vez que expressam benefícios e sentimentos no tocante aos comportamentos de promoção de saúde, podendo impactar positivamente ou negativamente na adoção destes.

5.2.2.1 Classe 4: Consciência sobre os hábitos promotores de saúde 
Nesta classe, os verbos entender, ajudar, pensar e acontecer, associados às palavras gente, senhor, pessoas, importante e problema, remetem, dentro do contexto, a relação de importância que os sujeitos atribuem aos comportamentos de promoção da saúde.

A promoção da saúde está relacionada com aspectos sociais, culturais, econômicos e políticos na sociedade para alcançar um desenvolvimento social mais equitativo, necessitando, dessa forma, de parcerias intersetoriais; possui um enfoque mais amplo e abrangente e é consequente a uma mudança de visão do que realmente é a saúde (SUCUPIRA; MENDES, 2003).

A prevenção possui como objetivo final evitar a ocorrências de doenças e a perda do bem-estar (HEIDEMANN, WOSNY, BOEHS, 2014; SUCUPIRA, MENDES, 2003); já a promoção da saúde vai além, pois possui um objetivo contínuo, que é a busca pelo bem-estar, pela qualidade de vida, pelo empoderamento individual e pelo potencial máximo de saúde, não estando associada apenas à presença ou não de doenças (HEIDEMANN et al., 2012; SUCUPIRA, MENDES, 2003).

\footnotetext{
"Assim, a promoção da saúde deve considerar a autonomia e a singularidade dos sujeitos, das coletividades e dos territórios, pois as formas como eles elegem seus modos de viver, como organizam suas escolhas e como criam possibilidades de satisfazer suas necessidades dependem não apenas da vontade ou da liberdade individual e comunitária, mas estão condicionadas e determinadas pelos contextos social, econômico, político e cultural em que eles vivem" (BRASIL, 2015c, p. 8).
}

Dessa forma, analisando os fatos encontrados, pode-se perceber que, após a prisão e o diagnóstico de HIV/Aids, os entrevistados passaram a se preocupar mais com sua saúde e a do próximo, adotando comportamentos e hábitos de vida saudáveis mesmo com todas as barreiras existentes no local. Isso demonstra que os sujeitos recebem orientações sobre promoção da saúde e hábitos saudáveis, uma vez que eles possuem consciência sobre a importância de se adotarem novos hábitos de vida.

[...] eu tô dormindo no chão gelado, tô adoecendo por causa disso, entendeu? As celas cheias demais, sem colchão, tá faltando muito recurso pra gente. O sistema penitenciário não ajuda muito! Eles ajuda em algumas coisas como: pagar a nossa medicação, as vitamina que a gente precisa, uma dieta, mas, nesse termo, de você tá morando numa cela de oito preso tendo vinte e seis preso dormindo no chão, sem colchão (E 9).

[...] não descuidar, né, se caso tiver um corte, um machucado, e alguém que não sabe querer vim me ajudar, eu já penso, e falo: "Olha! Não encosta porque eu 
tenho HIV”. [...] E ai, tu tem que ter a consciência pra que nada disso aconteça, pra pessoa não ser prejudicada (E 10).

[...] desse dia até hoje, eu uso todo dia, mais por causa da minha sobrevivência até, né? (E 12).

No universo da soropositividade para o HIV, sabe-se que o sofrimento físico e psicológico ocasionado após o diagnóstico da doença traz consigo uma gama de responsabilidades associadas inicialmente com a aceitação da doença, a manutenção das relações sociais e a necessidade de autoproteção. Dessa forma, os indivíduos passam a refletir e repensar sobre seus atos, adotando mudanças comportamentais em busca de qualidade de vida e bem estar (LEMOS et al., 2013; LIMA et al., 2011).

Ao serem questionados sobre terem recebido informações acerca de comportamentos de promoção da saúde que levam a uma melhor qualidade de vida, apenas cinco sujeitos relataram já terem recebido esse tipo de orientação e, destes, todos mencionaram a equipe de saúde do presídio.

Palestras que tinham aqui com o Doutor... Exercício físico... Evitar comer comida remosa como carne de porco, essas coisas, assim. É... Não fumar... (E 2).

Orientações do pessoal da saúde. Tomar os medicamentos no horário certo, dormir bem, evitar envolvimento com drogas. É isso aí, tudo que prejudica a gente (E 9).

Atualmente, apesar de vários avanços, ainda há a necessidade de uma reorientação no conceito de promoção e educação em saúde, colocando em foco o princípio da integralidade, empoderamento e participação social. Os profissionais de saúde necessitam desenvolver uma relação paciente-profissional pautada na escuta qualificada, no respeito e na valorização das experiências, das histórias de vida e da visão de mundo, principalmente profissionais que atuam na saúde prisional, uma vez que essa população possui características próprias e bem peculiares, que interferem diretamente em seu estado atual de saúde, devendo ser respeitadas e valorizadas (CARNEIRO, 2011).

Em um estudo desenvolvido por Costa, Oliveira, Formozo (2015), para se avaliar as representações sociais dos portadores de HIV/Aids em relação ao setor saúde, pôde-se perceber o impacto que a equipe de saúde possui na qualidade de vida dessa população, uma vez que o entrevistados relacionaram o processo de adesão ao tratamento, que envolve a 
presença nas consultas, realização de exames, a retirada da medicação e a autoadministração, ao excelente perfil do atendimento que recebiam pelos profissionais de saúde.

A Enfermagem é a profissão da área da saúde cuja essência e especificidade é o cuidado ao ser humano, seja no âmbito individual, familiar ou coletivo, contemplando atividades de promoção, prevenção e recuperação da saúde (BORELLI; MURAI, 2001). O enfermeiro é considerado o profissional ideal para desenvolver e comandar atividades de educação e promoção da saúde, sendo capaz de conscientizar e despertar na população a necessidade e o desejo de mudanças para alcançar uma vida de melhor qualidade (BORELLI, MURAI, 2001; OLIVEIRA et al., 2014).

A educação em saúde deve ser pautada nas características e expectativas dos portadores de HIV/Aids, e, por se tratar de um grupo bastante heterogêneo, é de suma importância levar em consideração vários aspectos, como a capacidade cognitiva do infectado, o grau de escolaridade, a cultura, o sexo, a faixa etária, orientação sexual, a raça/etnia, religião e outras características (SOUSA; SILVA, 2013).

\footnotetext{
"Para desenvolver estas ações, é necessário o conhecimento destas práticas educativas por parte destes trabalhadores, considerando que é essencial conhecer o olhar do outro, interagir com ele e reconstruir coletivamente saberes e práticas cotidianas" (CARNEIRO, 2011, p. 65).
}

Outra forma de se aumentar o vínculo com os pacientes e fortalecer as ações de educação e promoção da saúde dentro de ambientes prisionais, seria a realização de grupos, pois, segundo estudo realizado por Lemos et al. (2013) com portadores de HIV/Aids, as mudanças positivas ocorridas no dia a dia dos pacientes não foram resultados somente dos atendimentos e acompanhamentos individuais, mas também da presença dos grupos temáticos. Nesses ambientes, os pacientes interagem entre si contribuindo uns com os outros a partir de suas vivências e experiências, despertando entre eles sentimentos de compreensão e ajuda mútua, que interferem em uma melhor aceitação e compreensão da doença, possibilitando, dessa forma, se sentirem responsáveis pela sua própria saúde e pela saúde da comunidade a que pertencem, passando a adotar atitudes promotoras de crescimento e bemestar em busca de uma melhor qualidade de vida.

5.2.2.2 Classe 5: Hábitos adotados para a promoção da saúde 
Nesta classe as palavras encontradas com maior frequência no relato dos entrevistados foram física, alimentação, banho de sol, mente e remédio, que, associadas aos verbos poder, ver e fazer, refletem os benefícios adquiridos pela adoção dos novos hábitos de promoção à saúde, que proporcionam a essa população melhor qualidade e expectativa de vida.

Neste estudo, percebemos que a maioria dos entrevistados anteriormente à descoberta da infecção adotava como comportamentos de promoção da saúde apenas a realização de atividade física e cuidados com a alimentação.

A alimentação era normal, mais só física mesmo (E 6).

Eu acho que eu não tinha vida saudável não, só mesmo uma boa alimentação, uma física de vez em quando (E 7).

Após a descoberta da infecção pelo HIV/Aids, percebe-se que a busca por outros comportamentos de promoção da saúde e hábitos saudáveis passou a estar presente no dia a dia dessas pessoas, com o objetivo de se melhorar a qualidade de vida, e consequentemente prolongar a expectativa de vida.

Em primeiro lugar, eu tomo corretamente os medicamentos e as vitaminas, faço exercícios físicos, durmo bem... porque eu não posso perder mais noite de sono igual perdia antes... e também não fico encucado com esse problema aí... (E 2).

Eu procuro me alimentar o melhor possível, né... procuro também não usar drogas, e atividade física eu faço também (E 3 ).

Pelo relato de alguns participantes, percebe-se que as barreiras encontradas devido às questões estruturais e de recursos humanos, não impedem a adoção desses novos hábitos, pois eles tentam, na medida do possível, adotar comportamentos de promoção da saúde e seguir as orientações que recebem da equipe, para que possam viver com maior qualidade de vida.

Muitas vezes esses comportamentos ocorrem por meio de improvisos nas celas, utilizando da criatividade, jogos e reciclagem com baldes, cordas e garrafas; porém, a utilização de alguns materiais são proibidos nas penitenciárias, mas mesmo assim os detentos tentam "burlar o sistema" para se livrarem da ociosidade instalada ou mesmo pela necessidade de realização de tal prática. 
[...] a física, às vezes, sim. Porque nós, quando nós faz ela com o balde, né, aí tem que fazer a corda, e é proibida a corda aqui dentro do presídio (E 8).

Porque tem dia que a gente não tem o que fazer, e já fica numa cela, num espaço pequeno, e a gente não tem como sair e, às vezes, fica sem o banho de sol ou alguma coisa assim, então a gente procura outras atividades: faz um xadrez, faz exercitar a mente, puxa um assunto diferente (E 11).

Sabe-se, atualmente, que a adoção de hábitos saudáveis, como a prática regular de atividade física, associada a uma boa alimentação, possui impactos positivos na qualidade de vida da população em geral, independentemente de qualquer tipo infecção ou agravo. Os portadores de HIV/Aids do Complexo Penitenciário da Papuda, ao serem indagados sobre os benefícios desses hábitos e comportamentos, relataram serem muito positivos para a saúde e o bem-estar geral.

O cara pega peso e não esmagrece tanto. E com certeza vai viver mais do que os outros, né (E 6).

Eu acho que tanto pro corpo quanto pra mente, né (E 7).

Vejo porque, assim: eu tô dormindo na hora adequada, e apesar, assim, de que eu tô tendo insônia à noite, mas a física, um pouco, tá me ajudando a combater essa insônia (E 8).

Vejo benefício. Porque se eu não me cuidar, procurar me cuidar o máximo possível, independente de tá aqui preso [...], mas eu tenho que buscar a melhor forma possivel pra mim ter uma melhor qualidade de vida possivel aqui dentro. Entendeu? (E 9).

Muitos estudos comprovam os benefícios da atividade física para portadores do HIV/Aids, já que a utilização de ARVS a longo prazo acarreta uma série de alterações endócrinas, metabólicas e cardiovasculares.

Alterações físicas estão relacionadas à melhora da força e ganho de massa muscular, ganho de peso e melhora do condicionamento físico, redução da gordura abdominal total e da gordura abdominal central (OLIVEIRA, ALVES, PAES, 2013; PINTO et al., 2013; RODRIGUES, TOIGO, 2015), alterações significativas favoráveis da pressão arterial sistólica (LAZZAROTTO et al., 2014), diminuindo assim o risco às doenças cardiovasculares (LAZZAROTTO et al., 2014; OLIVEIRA, ALVES, PAES, 2013; PINTO et al., 2013; RODRIGUES, TOIGO, 2015).

Mudanças no estado psicológico também podem ser observadas com a prática de atividade física, uma vez que alterações na composição corporal ocasionam uma melhora na 
autoestima; devido à sensação de bem-estar, há também diminuição do estresse, ansiedade, agressividade e quadros depressivos, além de uma sensação positiva de inclusão social e melhora da qualidade de vida (FECCHIO et al., 1998; OLIVEIRA, ALVES, PAES, 2013; PINTO et al., 2013).

Estudo realizado por Fecchio et al. (1998) concluiu que a prática regular moderada de exercícios físicos pode melhorar a imunidade do indivíduo, retardando a infecção e consequentemente prorrogar a Aids.

Já em uma revisão sobre exercício físico e HIV/Aids, desenvolvida por Raso et al. (2007), pôde-se concluir que a prática de atividade física regular traz benefícios ao indivíduo, uma vez que aumenta o consumo máximo de oxigênio e os níveis de hemoglobina, assim como há uma melhora significativa em relação à qualidade de vida desses indivíduos. Porém, não foi possível concluir se a prática de atividade física proporciona alterações em parâmetros celulares, como a contagem de linfócitos TCD4+ e a carga viral.

Dessa forma, é necessário aumentar o nível de atividade física regular das PVHA desde o acompanhamento inicial, objetivando trabalhar a prevenção de agravos e auxiliar no tratamento complementar aos eventos adversos da infecção pelo HIV e pelo uso da medicação antirretroviral (BRASIL, 2013b).

A alimentação saudável, compreende uma ingesta adequada de proteínas, carboidratos, lipídios, minerais, fibras e água, sendo essencial para a manutenção do desempenho e da composição corporal, otimizando o ganho de massa muscular e reduzindo a gordura corporal. Em portadores de HIV/Aids, além de preservar o sistema imunológico, melhorar a tolerância aos antirretrovirais e favorecer a sua absorção, previne os efeitos colaterais dos medicamentos, melhorando o desempenho físico e mental, e consequentemente proporciona uma melhor qualidade de vida para essa população (BRASIL, 2013b).

O estado nutricional do paciente com Aids vem sofrendo alterações com o passar dos anos e com a evolução dos ARVS, diminuindo significativamente os casos graves de desnutrição. Mesmo com esse avanço, a monitoração do peso é de fundamental importância, uma vez que possibilita reconhecer alterações nutricionais existentes, bem como alterações fisiológicas e biológicas que podem estar associadas a diversos fatores como a adesão e não adesão ao tratamento antirretroviral, e à presença de infecções oportunistas (SILVA, A. et al., 2015). 
A perda ponderal é um fator agravante da infecção e reduz a qualidade de vida do paciente, estando diretamente associada à busca pelo atendimento e acompanhamento médico, sendo por PVHA ou até mesmo para a realização de testes de rotina para diagnóstico da doença, uma vez que esta ainda é muito associada ao emagrecimento (SILVA, A. et al., 2015).

Estudo realizado com pacientes em uso de antirretrovirais, em relação às alterações nutricionais e metabólicas, demonstrou que a diminuição dos níveis de hemoglobina e hematócrito, que caracterizam anemia, estavam presentes principalmente em pacientes com menor tempo de infecção; a desnutrição foi presente em pacientes com maior tempo de diagnóstico da doença; e o aumento dos níveis de colesterol e triglicerídeos estava presentes em todas as faixas da doença (SILVA; BURGOS; SILVA, 2010).

Em pacientes portadores de HIV/Aids, avaliados em relação ao IMC (Índice de Massa Corporal), contatou-se que 65\% encontravam-se eutróficos, $20 \%$ magreza I e $15 \%$ sobrepeso (SILVA, A. et al., 2015); corroborando com este estudo, Silva et al. (2014) observaram que, em sua população estudada, 65,8\% dos pacientes apresentaram estado nutricional de eutrofia, porém, quanto à dislipidemia, verificou-se que 43,0\% dos pacientes apresentaram hipercolesterolemia, 63,3\% hipertrigliceridemia, 24,0\% colesterol HDL baixo e $6,3 \%$ apresentaram colesterol LDL alto.

Já outro estudo também revelou baixa prevalência de desnutrição, entretanto, 88,3\% dos pacientes apresentaram hiperglicemia, hiperlipidemia e obesidade central (SILVA et al., 2010).

Dessa forma, as orientações nutricionais devem estar presentes desde o início do diagnóstico, e necessitam, impreterivelmente, articular com um programa de exercícios físicos, a fim de se estabelecer uma conduta que proporcione melhores resultados ao paciente, garantindo assim uma melhor qualidade de vida (BRASIL, 2013b).

\subsection{ADAPTAÇÃO AO MODELO DE PROMOÇÃO DA SAÚDE DE NOLA PENDER}

Os resultados das análises de conteúdo das cinco categorias permitiu relacionar cada uma delas ao Modelo de Promoção da Saúde proposto por Nola Pender. Assim, foi possível estabelecer um plano de ação com o objetivo de otimizar a adesão aos comportamentos de 
promoção da saúde da população carcerária do estudo, conforme representado no diagrama abaixo (FIGURA 3).

A primeira categoria do Modelo de Promoção da Saúde, de Nola Pender, características e experiências individuais, revelou claramente as vulnerabilidades dos participantes à infecção pelo HIV/Aids e também como os fatores pessoais são preditores desses comportamentos. Esta categoria interfere diretamente nos comportamentos de promoção da saúde, por estar relacionada com o modo de vida, as crenças e costumes dos mesmos; porém, o que se pode perceber foi que o comportamento anterior é passível de mudanças por meio de orientações e da conscientização quanto à importância dos cuidados com a saúde (FIGURA 3).

O núcleo central da teoria, comportamento específico, demonstrou que, apesar das inúmeras barreiras existentes como a superlotação e condições físicas do ambiente, alimentação precária, banho de sol curto, a dependência de outras pessoas e as situações enfrentadas no dia a dia na penitenciária, não fez com que as pessoas que vivem com HIV/Aids perdessem a esperança em buscar seus direitos e uma melhor qualidade de vida por meio da adoção de comportamentos de promoção da saúde.

Dentro das limitações existentes, percebe-se que os participantes procuram sempre que possível adotarem comportamentos de promoção da saúde, como a adesão ao tratamento, prática da atividade física e alimentação equilibrada, e isso ocorre porque essa população possui sentimentos positivos em relação a tais comportamentos, autoeficácia para a realização dos mesmos, e consegue perceber os benefícios à sua saúde por intermédio da adoção desses hábitos (FIGURA 3).

A terceira categoria, resultado do comportamento e das experiências, representa as intervenções de enfermagem para se alcançar os objetivos, que são os comportamentos de promoção da saúde que podem ser implementados no Complexo Penitenciário do Distrito Federal, a fim de se melhorar a qualidade de vida desta população. Porém, a adoção desses comportamentos podem sofrer interferências por meio das exigências imediatas ou preferências, como os procedimentos rotineiros do presídio que visam assegurar a segurança e a disciplina do local, ou até mesmo pelas preferências do próprio indivíduo em relação a determinado comportamento (FIGURA 3).

Nas populações privadas de liberdade, mudar o comportamento de um indivíduo ou de um grupo a respeito de sua saúde e do seu meio, e mudar também a ideologia punitiva da 
instituição, é uma tarefa árdua, que exige paciência, intersetorialidade e habilidades (PIRES et al., 2014).

Ao se pensar em um plano de ação ou em um processo de trabalho, é necessário refletirmos sobre os limites e possibilidades presentes em seu território de atuação -nesse caso o sistema penitenciário -, mas nunca deixando de cumprir as responsabilidades diante dessa população privada de liberdade. Dessa forma, são necessários esforços da equipe de saúde para se conhecer as condições em que vivem as pessoas privadas de liberdade, as representações sociais atribuídas por elas à saúde e às doenças, bem como os prováveis fatores que determinam e condicionam o aparecimento e a manutenção dessas enfermidades (PIRES et al., 2014).

Como um profissional de saúde atuante no âmbito prisional, percebo que apenas a teoria e a prática do cuidar não são suficientes para sanar todos os problemas de saúde existentes nesses locais. Trabalhar com pessoas privadas de liberdade exige um pensamento além das práticas do dia a dia, é preciso inovar e buscar recursos para inserir essa população nas ações de saúde, comprometendo-os com o seu autocuidado e corresponsabilizando-os com o seu estado de saúde.

Para que os comportamentos de promoção da saúde - como a prática regular de atividade física, alimentação balanceada, adesão ao tratamento, sono e repouso satisfatórios e atividades laborativas - passem a ser uma realidade dos portadores de HIV/Aids reclusos no Sistema Penitenciário do Distrito Federal, entende-se ser de fundamental importância que a equipe de saúde, sobretudo a equipe de enfermagem, desenvolva o vínculo com seus pacientes para que haja uma relação de confiança e respeito entre ambos, com o objetivo de mitigar as barreiras existentes, a fim de potencializar a adesão a esses comportamentos.

É preciso ter clareza do papel transformador e multiplicador de conhecimento, com vistas a contribuir no processo educativo e preventivo que o enfermeiro, como integrante da equipe multiprofissional, possui. Observa-se, na prática clínica, que as ações de promoção da saúde, muitas vezes já são pré-determinadas pelos enfermeiros e demais profissionais, sem levar em consideração a individualidade do paciente e ao contexto em que o mesmo está inserido, podendo esses fatos resultar em baixa adesão às intervenções propostas.

Nesse cenário, a sugestão de aplicação da teoria de Nola Pender permitiu elaborar uma proposta de assistência integral e qualificada, que possa resultar na implementação de 
intervenções de enfermagem de modo organizado e sistematizado no âmbito da promoção da saúde e nas mudanças de comportamento e estilo de vida.

Uma nova proposta de atendimento a essa população seria algo inovador e bastante valioso, uma vez que investir na educação e promoção à saúde por meio da implementação de grupos propiciaria o compartilhamento de vivências e a troca de experiências entre os profissionais e os pacientes, tanto das questões relacionadas com a doença e o tratamento, como também com o modo de vida e as peculiaridades das pessoas privadas de liberdade.

Além disso, a equipe de enfermagem deve sensibilizar os profissionais de segurança pública quanto aos desafios de se viver com HIV/Aids em um ambiente prisional, quanto a ter noção da importância do cuidado a essa população, a fim de garantir pelo menos os direitos mínimos necessários para se viver com dignidade e qualidade de vida. Parcerias podem ser propostas, estudadas e estabelecidas, como oportunizar os estudos e atividades laborativas a essa população, organizar um ambiente seguro e humanizado para a realização dos atendimentos individuais ou grupais, aumentar a fiscalização quanto às dietas fornecidas e realocá-los em celas específicas para proporcionar maior conforto, e assim também facilitar ações diferenciadas da equipe de saúde. 
FIGURA 3 - MODELO DE PROMOÇÃO DA SAÚDE DE NOLA PENDER ADAPTADO PARA OS PORTADORES DE HIV/AIDS EM PRIVAÇÃO DE LIBERDADE. BRASÍLIA, 2016

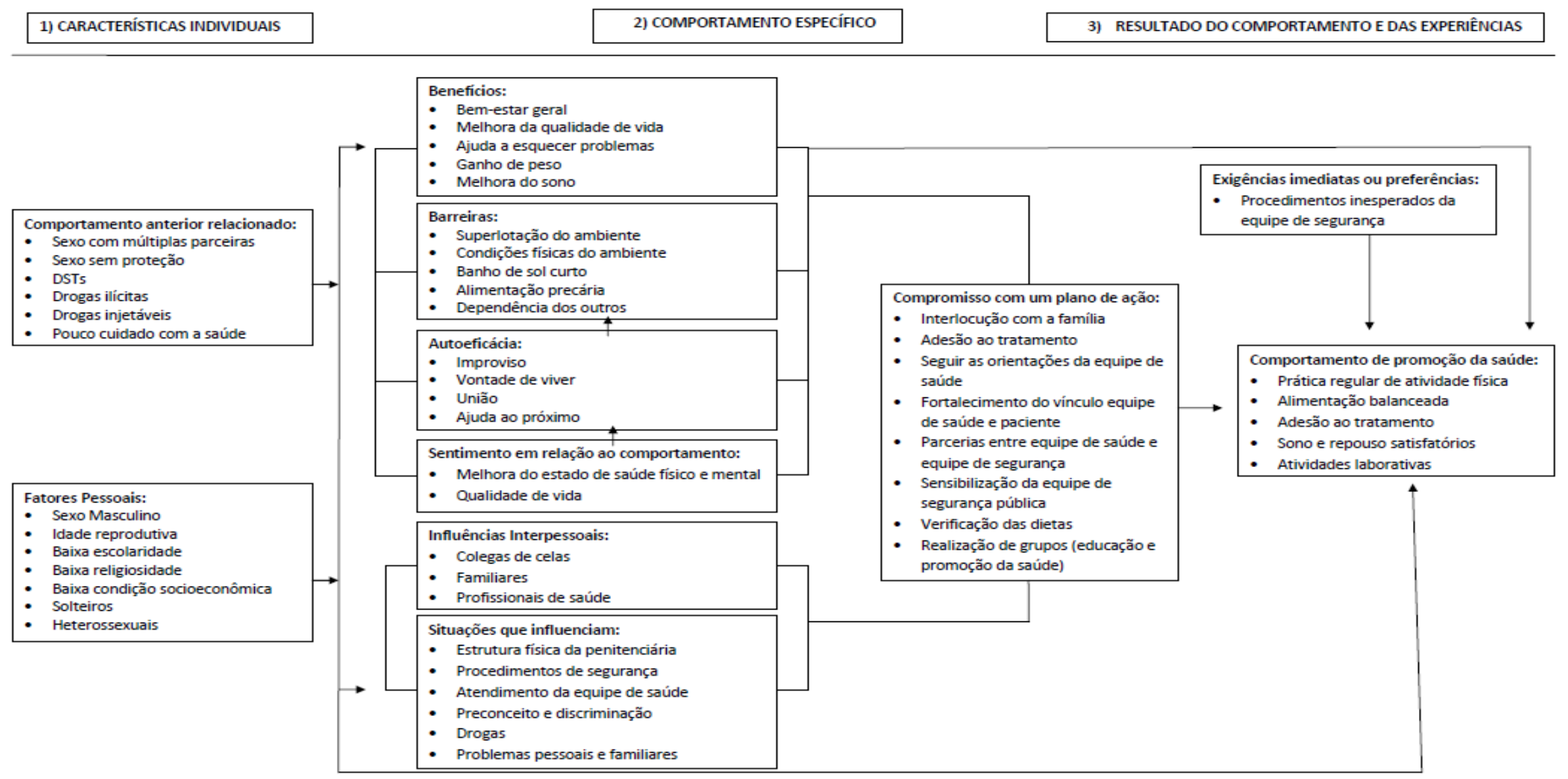

FONTE: Adaptado do Modelo de Promoção da Saúde de Nola Pender. 


\section{CONSIDERAÇÕES FINAIS}

Os resultados do estudo apontaram que o perfil dos entrevistados assemelha-se ao relatado em outros estudos realizados com pessoas privadas de liberdade. Assim, parecem confirmar as características da população carcerária brasileira, que é composta por adultos jovens, solteiros, de baixa escolaridade, com pouca vinculação religiosa e exercendo profissões de baixa remuneração.

Pôde-se apreender, ainda, que as características individuais, relacionadas aos comportamentos anteriores adotados pelos participantes, revelaram grandes exposições às vulnerabilidades de infecção pelo HIV, uma vez que essa população relatou sexo sem proteção e com múltiplas parceiras, uso de drogas ilícitas, ocorrência de DSTs e baixa procura aos serviços de saúde.

Essas características, somadas às vulnerabilidades sociais apontadas no perfil dos entrevistados, significam um impacto negativo na adoção de comportamentos de promoção da saúde, sobretudo, devido às resistências para procurar informações adequadas, influenciando a compreensão e/ou tomada de decisão para autoproteção da saúde. Contribui ainda, para as vulnerabilidades pessoais, as concepções equivocadas acerca das representações sobre masculinidade.

Quanto a ser portador do HIV/Aids e viver no cárcere, os participantes relataram muitas dificuldades, sendo que a superlotação e as condições de infraestrutura figuram como os principais motivos das limitações para a promoção da saúde.

A leitura dos comportamentos conforme a teoria de Nola Pender, apontam que as queixas apresentadas pelos participantes constituem as barreiras e as situações que influenciam nos comportamentos promotores de saúde, e podem interferir de maneira negativa na adoção de novos hábitos.

Porém, foi possível perceber que, apesar das inúmeras barreiras existentes dentro do sistema penitenciário, os participantes do estudo estão sensíveis quanto à importância da adoção de alguns hábitos que podem favorecer uma condição mais saudável. Na perspectiva deles, são: a prática regular de atividade física, uma alimentação equilibrada, adesão ao tratamento proposto, sono e repouso satisfatórios e atividades laborativas. Por perceberem os benefícios na melhora do bem-estar, ganho de peso e na melhoria na qualidade do sono, 
entendem que sua qualidade e expectativa de vida podem ser beneficiadas com adoção desses hábitos, e assim buscam, sempre que possível, praticá-los.

Pode-se inferir que a adesão a esses novos comportamentos saudáveis, associada aos sentimentos positivos, foi possível devido ao trabalho realizado pela equipe de saúde do local, principalmente pela equipe médica e de enfermagem. As orientações gerais e a educação em saúde revelam êxito quanto à conscientização dos sujeitos sobre a importância de tais práticas.

Dessa forma, pode-se dizer que, apesar das limitações quanto à infraestrutura e superlotação, que constituem barreiras importantes para adoção de hábitos saudáveis, o trabalho da equipe de enfermagem é primordial para que as ações de promoção da saúde sejam eficazes e minimizem os danos à saúde das pessoas privadas de liberdade. É necessário que a equipe de enfermagem discuta o plano de ação proposto no estudo, buscando aperfeiçoá-lo a fim de fortalecer o vínculo paciente-profissionais de saúde. O trabalho de sensibilização da equipe de segurança, propondo parcerias entre ela e a equipe de saúde, também deve ser apreciada pela equipe de enfermagem. Entende-se que novas ações e condutas podem ser implementadas a fim de se mitigar as barreiras existentes e otimizar a qualidade de vida dessa população.

Os resultados do estudo permitiram, ainda, comprovar que a enfermagem dispõe de um modelo/teoria próprio, que demostrou ser objetivo, de fácil entendimento, prático e abrangente.

Nesta perspectiva, apontamos o Modelo de Promoção da Saúde de Nola Pender como uma possibilidade para subsidiar o planejamento das ações de promoção da saúde em contextos prisionais. Assim, destaca-se a necessidade de os enfermeiros reconhecerem a importância das bases teóricas para o fortalecimento científico da profissão, na busca da prestação de uma assistência integral e resolutiva, baseada em evidências e apoiadas em teorias de enfermagem.

Como desdobramento deste estudo, espera-se que as equipes de saúde do Complexo Penitenciário do Distrito Federal e de outras penitenciárias compreendam a necessidade de reorientar o processo de trabalho em saúde vigente no interior desses estabelecimentos, aprofundando os conhecimentos em relação à promoção da saúde e aos agravos que mais acometem a população privada de liberdade no Brasil. 


\section{REFERÊNCIAS}

AERTS, A. et al. Tuberculosis and tuberculosis control in European prisons. The International Journal of Tuberculosis and Lung Disease, v. 10, n. 11, p. 1215-1223, nov. 2006. Disponível em:

<http://www.ingentaconnect.com/content/iuatld/ijtld/2006/00000010/00000011/art00006?tok en=004a1474f49439412f415d76552573453a2b452a5a6376253048296a7c2849266d656c98d7 \#aff_1>. Acesso em: 16 fev. 2016.

ALMEIDA, E. L. et al. Adesão dos portadores do HIV/Aids ao tratamento: fatores intervenientes. Revista Mineira de Enfermagem, Belo Horizonte, v.15, n.5, p. 208-216, jan./mar. 2011.

ALQUIMIM, A. F. Comportamento de risco para HIV em população carcerária de Montes Claros (MG). Revista Unimontes Científica, Montes Claros, v. 16, n.1, p. 48-54, jan./jun. 2014.

ARRIOLA, K. R. et al. A collaborative effort to enhance HIV/STI screening in five county jails. Public Health Reports, v. 116, n. 6, p. 520 - 529 nov./dez. 2001. Disponível em: <http://www.ncbi.nlm.nih.gov/pmc/articles/PMC1497374/pdf/12196611.pdf>. Acesso em: 18 fev. 2016.

ASSIS, R. D. A realidade atual do sistema penitenciário brasileiro. Revista CEJ, Brasília, ano XI, n.39, p. 74-78, out./dez. 2007.

BARBOSA, M. L. et al. Atenção básica à saúde dos apenados no sistema penitenciário: subsídios para a atuação da enfermagem. Escola Anna Nery Revista de Enfermagem, Rio de Janeiro, v.18, n.4, p. 586-592, out./dez. 2014.

BARRY, P. M. et al. Is jail screening associated with a decrease in Chlamydia positivity among females seeking health services at community clinics?-San Francisco, 1997-2004.

Sexually Transmitted Diseases, v.2, suppl.2, p. 22-28, fev. 2009. Disponível em: <http://www.ncbi.nlm.nih.gov/pubmed/18418298 >. Acesso em: 20 fev. 2016.

BECKWITH, C. G. et al. An evaluation of a routine opt-out rapid hiv testing program in a Rhode Island Jail. AIDS Education and Prevention, v. 23, n. 3, p. 96 -109, jun. 2011. Disponível em: 〈http://www.ncbi.nlm.nih.gov/pubmed/21689040>. Acesso em: 7 jan. 2016.

BONE, A. et al. Tuberculosis control in prisons. A manual for programme managers. Geneva: World Health Organization, International Committee of the Red Cross, 194 p., 2000. Disponível em: $<$ http://apps.who.int/iris/bitstream/10665/66823/1/WHO_CDS_TB_2000.281.pdf $>$. Acesso em:01 mar. 2016.

BORELLI, M.; MURAI, H. C. Ações educativas do enfermeiro na promoção da saúde: revisão. Revista de Enfermagem da UNISA. v.2, p.122-124, 2001. 
BRASIL. Lei no 7.210, de 11 de julho de 1984. Institui a lei de execução penal. Brasília, 1984. Disponível em: <http://www.planalto.gov.br/ccivil_03/leis/17210.htm>. Acesso em: 10 dez. 2015.

Ministério da Justiça. Departamento Penitenciário Nacional. Sistema Integrado de Informações Penitenciárias. Levantamento Nacional de Informações Penitenciárias Infopen. Brasília, 2014a. 148 p.

. Ministério da Saúde. Conselho Nacional de Saúde. Resolução n 466/2012 de 12 de dezembro de 2012. Aprova as diretrizes e normas regulamentadoras de pesquisas envolvendo seres humanos. Brasília, 2012.

. Secretaria de Atenção à Saúde. Departamento de Ações Programáticas Estratégicas. Área Técnica de Saúde da Mulher. Pré-natal e puerpério: atenção qualificada e humanizada - manual técnico. Brasília, 2006. 162 p.

Área Técnica de Saúde no Sistema Penitenciário. Plano Nacional de Saúde no Sistema Penitenciário. Brasília, 2004.

Secretaria de Políticas de Saúde. Projeto Promoção da Saúde. As cartas da promoção da saúde. Brasília, 2002. 56 p.

. Secretaria de Vigilância em Saúde. Departamento de Análise de Situação e Saúde. Política Nacional de Promoção da Saúde: PNPS: revisão da portaria MS/GM no 687, de 30 de março de 2006. Brasília, 2015c. 38 p.

. Secretaria de Vigilância em Saúde. Departamento de DST, Aids e Hepatites Virais. Aids. 2015b. Disponível em: 〈http://www.aids.gov.br/aids>. Acesso em: 01 mar. 2016.

$\overline{68 \mathrm{p} .} \cdot-\cdot \longrightarrow$ Boletim Epidemiológico Aids e DST. Brasília, 2013a.

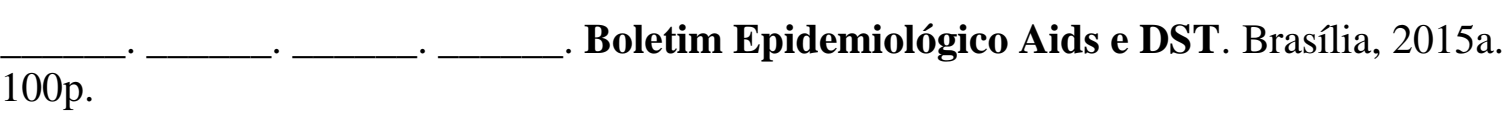

Ciência começa a desvendar portadores de HIV que não desenvolvem a doença. 2005. Disponível em: 〈http://www.aids.gov.br/noticia/cienciacomeca-desvendar-portadores-de-hiv-que-nao-desenvolvem-doenca-ultimo-segundo >. Acesso em: 2 abr. 2016

HIV. 2 ed. Brasília, 2014d. 74p.

Manual técnico para o diagnóstico da infecção pelo

Protocolo clínico e diretrizes terapêuticas para atenção integral às pessoas com infecções sexualmente transmissíveis. Brasília, 2015d. 2 ed. 122p. 
BRASIL. Ministério da Saúde. Secretaria de Vigilância em Saúde. Departamento de DST, Aids e Hepatites Virais. Protocolo clínico e diretrizes terapêuticas para o manejo da infecção pelo HIV em adultos. Brasília, 2013b. 227 p.

Departamento de Vigilância Epidemiológica. Manual de recomendações para o controle da tuberculose no Brasil. Brasília, 2011. 288 p.

Portaria n. $^{\circ}$ 482, de $1^{\circ}$ de abril de 2014. Institui normas para a operacionalização da Política Nacional de Atenção Integral à Saúde das Pessoas Privadas de Liberdade no Sistema Prisional (PNAISP) no âmbito do Sistema Único de Saúde (SUS). Brasília, 2014c.

Portaria Interministerial $\mathrm{n}^{\circ}$ 1, de 02 de janeiro de 2014. Institui a Política Nacional de Atenção à Saúde das Pessoas Privadas de Liberdade (PNAISP) no âmbito do Sistema Único de Saúde (SUS).Brasília, 2014b.

BRITO, V. O.C. et al. Infecção pelo HIV, hepatites B e C e sífilis em moradores de rua, São Paulo. Revista de Saúde Pública, São Paulo, v. 41, suppl. 2, p. 47-56, dez. 2007.

BUSS, P. M. Promoção da Saúde e Qualidade de Vida. Ciência \& Saúde Coletiva, Rio de Janeiro, v.5, n.1, p. 163-177, 2000.

CAMARGO, J.P. et al. O perfil das detentas HIV positivo de uma penitenciária estadual do Paraná, Brasil. Journal of the Health Scienses Institute, v. 30, n.4, p. 369-376, out./dez. 2012. Disponível em: $<$ http://www.unip.br/comunicacao/publicacoes/ics/edicoes/2012/04_outdez/V30_n4_2012_p369a376.pdf>. Acesso em: 20 mar. 2016.

CANUTO, J. M. P. et al. Fatores de risco associados à hipovitaminose D em indivíduos adultos infectados pelo HIV/aids. Archives of Endocrinology and Metabolism, São Paulo, v.59, n.1, p. 34-41, fev. 2015. Disponível em: <http://www.scielo.br/pdf/aem/v59n1/pt_23593997-aem-59-1-0034.pdf>. Acesso em: 5 abr. 2016.

CARDOSO, A. L; MARCON, S. S; WAIDNAMI, M. A. P. O impacto da descoberta da sorologia positiva do portador de HIV/Aids e sua família. Revista de Enfermagem da UERJ, Rio de Janeiro, v. 16, n. 3, p. 326-332. jul./set. 2008.

CARNEIRO, R. F. Promoção da Saúde: conhecimento produzido pelas equipes de enfermagem na estratégia saúde da família. SANARE Revista de Políticas Públicas, Sobral, v. 10, n. 2, p. 64-70, jul./dez. 2011.

CARVALHO, C. M. L.; GALVÃO, M. T. G.; SILVA, R. M. Alterações na vida de mulheres com Síndrome de Imunodeficiência Adquirida em face da doença. Acta Paulista de Enfermagem, São Paulo, v. 23, n. 1, p. 94-100, 2010.

CARTAXO, R. O. et al. Panorama da estrutura presidiária brasileira. Revista Brasileira em Promoção da Saúde, Fortaleza, v. 26, n. 2, p. 266-273, abr./jun. 2013. 
CAZANTI, R. F.; ENNE, R. V.; CRODA, J. H. R. Prevalência de HIV na população privada de liberdade do estado do Mato Grosso do Sul. In: ENCONTRO DE ENSINO PESQUISA E EXTENSÃO, 2014. Anais. Dourados: Universidade Federal da Grande Dourados, 2014. Disponível em: <http://eventos.ufgd.edu.br/enepex/anais/arquivos/430.pdf >. Acesso em: 05 mar. 2016.

CHRISTENSEN, P.B. et al. Prevalence and incidence of bloodborne viral infections among Danish prisoners. European Journal of Epidemiology, v. 16, n. 11, p. 1043-1049, 2000. Disponível em: 〈http://www.ncbi.nlm.nih.gov/pubmed/11421474〉 . Acesso em: 23 fev. 2016.

CLAY, P. G. et al. Meta- analysis os studies comparing single and multi-tablet fixed dose combination HIV treatment regimens. Medicine, v.94, n.42, p. 1-14, out. 2015. Disponível em: <http://www.ncbi.nlm.nih.gov/pmc/articles/PMC4620781/>. Acesso em: 04 mar. 2016.

COELHO, H. C. et al. Prevalência e fatores de risco para infecção pelo HIV em penitenciária brasileira. Caderno de Saúde Pública, Rio de Janeiro, v. 23, n. 9, p. 2197-2204, set. 2007.

COLE, J. et al. Opt-out screening for chlamydia trachomatis and Neisseria gonorrhoeae in female detainees at cook county jail in Chicago, IL. Sexually Transmitted Diseases, v. 41, n. 3, p. 161-165, mar. 2014. Disponível em: 〈http://www.ncbi.nlm.nih.gov/pubmed/24521720>. Acesso em 02 mar. 2016.

COLLIÈRE, M-F. Cuidar... A primeira arte da vida. 2 ed. Loures - Lisboa: Lusociência, 2003.

COLOMBRINI, M. R. C.; LOPES, M. H. B. M.; FIGUEIREDO, R. M. Adesão à terapia antirretroviral para HIV/Aids. Revista da Escola de Enfermagem da USP, São Paulo, v. 40, n. 4, p. 576-581, 2006.

COSTA, T. L.; OLIVEIRA, D. C.; FORMOZO, G. A. O setor saúde nas representações sociais do HIV/Aids e qualidade de vida de pessoas soropositivas. Escola Anna Nery Revista de Enfermagem, Rio de Janeiro, v. 19, n. 3, p. 475-483, jul./set. 2015.

DANTAS, G. E. et al. Percepções das pessoas vivendo com HIV/Aids frente ao tratamento antirretroviral. ID on line Revista Multidisciplinar e de Psicologia, v. 6, n. 17, p. 48-64, jul. 2012. Disponível em: <http://idonline.emnuvens.com.br/id/article/view/193/193>. Acesso em: 22 mar. 2016.

DASSI, M. A. L. M. A pena de prisão e a realidade carcerária brasileira: uma análise crítica. 2006. Disponível em:

<http://www.publicadireito.com.br/conpedi/manaus/arquivos/anais/bh/maria_angelica_lacerd a_marin_dassi.pdf $>$. Acesso em: 20 fev. 2016.

DISTRITO FEDERAL. Secretaria de Estado de Justiça e Cidadania do Distrito Federal. Subsecretaria do Sistema Penitenciário. Gerência de Controle de Internos. Resenha Diária, mar. 2016a. 
DISTRITO FEDERAL. Secretaria de Estado de Saúde do Distrito Federal. Subsecretaria de Atenção Integral á Saúde. Coordenação de Atenção Primária à Saúde. Diretoria de Áreas Estratégicas de Atenção Primária. Gerência de Saúde no Sistema Prisional. Relatório de Agravos, mar. 2016b.

DIUANA, V. et al. Saúde em prisões: representações e práticas dos agentes de segurança penitenciária no RJ - Brasil. Caderno de Saúde Pública, Rio de Janeiro, v. 24, n. 8, p. 18871896, ago. 2008.

DOLAN, K. et al. HIV in prison in low-income and middle-income countries. The Lancet Infectious Diseases, v. 7, n. 1, p. 32-41, jan. 2007. Disponível em: <http://www.thelancet.com/journals/laninf/article/PIIS1473-3099(06)70685-5/abstract $>$. Acesso em: 28 jan. 2016.

FAGUNDES, V. H. V. et al. Infecções oportunistas em indivíduos com infecção pelo HIV e relação com o uso de terapia antirretroviral. Acta Scientiarum Health Scienses, Maringá, v. 32, n. 2, p. 141-145, 2010. Disponível em: $\langle$ http://periodicos.uem.br/ojs/index.php/ActaSciHealthSci/article/viewFile/4508/4508>. Acesso em: 25 mar. 2016.

FAZEL, S.; BAILLARGEON, J. The health of prisoners. The Lancet, v. 377, n.9769 p. 956965, mar. 2011. Disponível em: 〈http://www.thelancet.com/journals/lancet/article/PIIS01406736(10)61053-7/abstract >. Acesso em: 10 jan. 2016

FECHIO, J.J. et al. A influência da atividade física para portadores do vírus HIV. Revista Brasileira de Atividade Física e Saúde, São Paulo, v. 3, n. 2, p. 43-57, 1998.

FERNANDES, L. H. et al. Necessidade de aprimoramento à saúde no sistema carcerário. Revista de Saúde Pública, São Paulo, v. 48, n. 2, p. 275-283, abr. 2014.

FERRETI, M. A. C.; KNIJNIK, J. D. A prática esportiva e atividade física podem educar pessoas atrás das grades? Revista da Faculdade de Educação Física da UNICAMP, Campinas, v. 7, n. 3, p. 59-73, set./dez. 2009.

FIUZA, M. L. T. et al. Adesão ao tratamento antirretroviral: assistência integral baseada no modelo de atenção às condições crônicas. Escola Anna Nery Revista de Enfermagem, Rio de Janeiro, v. 16, n. 4, p. 740-748, out./dez. 2013.

FOUCAUlT, M. Vigiar e Punir: nascimento da prisão. 41 ed. Petrópolis, RJ: Vozes, 2013. $291 \mathrm{p}$.

FOX, R. K. et al. Hepatitis C virus infection among prisoners in the California state correctional system. Clinical Infectious Diseases, v. 41, n.2, jul. 2005. Disponível em: <http://cid.oxfordjournals.org/content/41/2/177.long>. Acesso em: 26 fev. 2016.

GALUCIO, I. A. S. Os impactos da assistência religiosa no processo de ressocialização de presos. In: CONGRESSO INTERNACIONAL DA FACULDADES EST, 1., 2012, São 
Leopoldo. Anais do Congresso Internacional da Faculdades EST. São Leopoldo: EST, v.1, 2012, p. 1219-1238. Disponível em:

<http://anais.est.edu.br/index.php/congresso/article/view/124/87>. Acesso em: 19 jan. 2016.

GALVÃO, M. C. B.; DAVIM, R. M. B. Ausência de assistência à gestante em situação de cárcere penitenciário. Cogitare Enfermagem, Curitiba, v. 18, n. 3, p. 452-459, jul./set. 2013.

GARCIA, S.; SOUZA, F. M. Vulnerabilidades ao HIV/aids no contexto brasileiro:

iniquidades de gênero, raça e geração. Saúde e Sociedade, São Paulo, v. 19, supl. 2, p. 9-20, dez. 2010.

GEOCZE, L. et al. Qualidade de vida e adesão ao tratamento antirretroviral de pacientes portadores de HIV. Revista de Saúde Pública, São Paulo, v. 44, n. 4, p. 743-749, ago. 2010.

GIACOMOZZI, A. I. Representações sociais da droga e vulnerabilidades de usuários de CAPSad em relação às DST/HIV/AIDS. Estudos e Pesquisa em Psicologia, Rio de Janeiro, v. 11, n. 3, p. 776-795, 2011.

GIR, E.; VAICHUNOLIS, C. G.; OLIVEIRA, M. D. Adesão à terapêutica antirretroviral por Indivíduos com HIV/Aids assistidos em uma instituição do interior paulista. Revista Latino Americana de Enfermagem, Ribeirão Preto, v.1, n.5, p. 634-641, set./out. 2005.

GOFFMAN, E. Manicômios, Prisões e Conventos. São Paulo, SP: Perspectiva, 1974. 316p.

GOIS, S. M. et al. Para além das grades e punições: uma revisão sistemática sobre a saúde penitenciária. Ciência \& Saúde Coletiva, Rio de Janeiro, v. 17, n. 5, p. 1235-1246, mai. 2012.

GONÇALVES, K.K. História de vida e situação de saúde no ambiente prisional de Goiás: estudo da prevalência de hepatite $\mathbf{C}$ em detentos. 2005. 95 f. Dissertação (Mestrado em Ciências Ambientais e Saúde) - Universidade Católica de Goiás, Goiânia. Disponível em: $\langle$ http://tede.biblioteca.ucg.br/tde busca/arquivo.php?codArquivo=30 >. Acesso em: $22 \mathrm{mar}$. 2016.

GUEDES, N. G. et al. Atividade física de escolares: análise segundo o modelo teórico de promoção da saúde de Pender. Revista Escola de Enfermagem da USP, São Paulo, v. 43, n. 4, p. 774-80, 2009.

GUERRIERO, I.; AYRES, J. R. C. M.; HEARST, N. Masculinidade e vulnerabilidade ao HIV de homens heterossexuais, São Paulo. Revista de Saúde Pública, São Paulo, v. 36, n. 4, p. 50-60, ago. 2002.

HALLAL, R. et al. O acesso universal ao tratamento antirretroviral no Brasil. Revista Tempus Actas em Saúde Coletiva. p. 53-65, 2013.

Disponível em: 〈http://www.tempus.unb.br/index.php/tempus/article/download/791/778>.

Acesso em: 01 mar. 2016. 
HARKZE, A. J. et al. Heterogeneity in hepatitis B virus (HBV) seroprevalence estimates from U.S. adult incarcerated populations. Annals of Epidemiology, v. 19, n. 9, p. 647-650, set. 2009. Disponível em: 〈http://www.ncbi.nlm.nih.gov/pmc/articles/PMC2856929/>. Acesso em: 26 fev. 2016.

HEIDEMANN, I.T. S. B. et al. Promoção à Saúde: trajetória histórica e suas concepções. Texto e Contexto Enfermagem, Florianópolis, v. 15, n. 2, p. 352-358, abr./jun. 2006.

Promoção da saúde e qualidade de vida: concepções da carta de Otawwa em produção científica. Ciência, Cuidado e Saúde, v. 11, n. 3, p. 613-619, jul./set. 2012.

WOSNY, A. M.; BOEHS, A. E. Promoção da saúde na atenção básica: estudo baseado no método de Paulo Freire. Ciência e Saúde Coletiva, Rio de Janeiro, v. 19, n. 8, p. 3553-3559, ago. 2014.

ILIAS, M.; CARANDINA, L.; MARIN, M. J. S. Adesão à terapia antirretroviral de portadores do vírus da imunodeficiência humana atendidos em um ambulatório da cidade de Marília, São Paulo. Revista Baiana de Saúde Pública, Salvador, v. 35, n. 2, p. 471-474, abr./jun. 2011.

KAVASERY, R. et al. A prospective controlled trial of routine opt-out HIV testing in a men's jail. PLoS One, v. 4, n. 11, p. 1-5, nov. 2009. Disponível em:

$\langle$ http://journals.plos.org/plosone/article/asset?id=10.1371\%2Fjournal.pone.0008056.PDF>. Acesso em: 22 jan. 2016.

LAZZAROTTO, A. R. et al. Treinamento físico no risco de doença isquêmica cardíaca em sujeitos HIV/AIDS em uso de TARV. Revista Brasileira de Medicina do Esporte, São Paulo, v. 20, n. 3, p. 233-236, mai./jun. 2014.

LEMOS, L. A. et al. Grupo de promoção da saúde para portadores do vírus da imunodeficiência humana. Revista de Enfermagem da UERJ, Rio de Janeiro, v. 21, n. 4, p. 521-526, out./dez. 2013.

LIMA, I. C. V. et al. Ações de promoção da saúde em serviço de assistência ambulatorial especializada em HIV/Aids. Ciência, Cuidado e Saúde, v. 10, n. 3, p. 556-563, jul./set. 2011.

LIMA, T. C.; FREITAS, M. I. P. Comportamentos em saúde de uma população portadora do HIV/Aids. Revista Brasileira de Enfermagem, Brasília, v. 65, n. 1, p. 110-115, jan./fev. 2012.

MACALINO, G. E. et al. Prevalence and incidence of HIV, hepatitis B virus, and hepatitis C virus infections among males in Rhode Island prisons. American Journal of Public Health, v. 94, n. 7, p. 1218-1223, jul. 2004. Disponível em: <http://www.ncbi.nlm.nih.gov/pmc/articles/PMC1448424/pdf/0941218.pdf $>$. Acesso em: 28 jan. 2016. 
MACHADO, V. G. O fracasso da pena de prisão: alternativas e soluções. Panóptica Direito, Sociedade e Cultura, v. 4, n. 3, p. 108-129, 2009.

MACNEIL, J. R.; LOBATO, M. N.; MOORE, M. An unanswered health disparity: tuberculosis among correctional inmates, 1993 through 2003. American Journal of Public Health, v. 95, n. 10, p. 1800-1805, out. 2005. Disponível em:

<http://www.ncbi.nlm.nih.gov/pmc/articles/PMC1449439/pdf/0951800.pdf>. Acesso em: 28 jan. 2016.

MAIA, C.; GUILHEM, D.; FREITAS, D. Vulnerabilidade ao HIV/Aids de pessoas heterossexuais casadas ou em união estável. Revista de Saúde Pública, São Paulo, v. 42, n. 2, p. 242-248, abr. 2008.

MALISKA, I. C .A. et al. Percepções e significados do diagnóstico e convívio com o HIV/Aids. Revista Gaúcha de Enfermagem, Porto Alegre, v. 30, n. 1, p. 85-91, mar. 2009.

MARIA, J. C. Insuficiência de vitamina D em pacientes infectados pelo HIV tratados com terapia antirretroviral contendo Tenofovir. 2015. 69 f. Dissertação (Mestrado em Ciências Nutricionais) - Faculdade de Ciências Farmacêuticas, Universidade Estadual Paulista, São Paulo. Disponível em:

<http://www.fcfar.unesp.br/arquivos/link/20151204155447jessika_carvalho_maia_me.pdf $>$. Acesso em: 5 abr. 2016.

MARQUES, H. H. S. et al. A revelação do diagnóstico na perspectiva dos adolescentes vivendo com HIV/Aids e seus pais e cuidadores. Caderno de Saúde Pública, Rio de Janeiro, v. 22, n. 3, p. 619-629, mar. 2006.

MARQUES JUNIOR, J. S.; GOMES, R.; NASCIMENTO, E. F. Masculinidade hegemônica, vulnerabilidade e prevenção ao HIV/AIDS. Ciência e Saúde Coletiva, Rio de Janeiro, v. 17, n. 2, p. 511-520, fev. 2012.

MARTINS, V. V. Saúde sexual de mulheres com estomia na perspectiva da teoria de Nola Pender. 2013. 179 f. Dissertação (Mestrado em Enfermagem) - Faculdade de Enfermagem, Universidade do Estado do Rio de Janeiro, Rio de Janeiro. Disponível em: $\langle$ http://www.bdtd.uerj.br/tde busca/arquivo.php?codArquivo=5200 $>$. Acesso em: 28 jan. 2016.

MARTINS, E. L. C. et al. O contraditório direito à saúde de pessoas em privação de liberdade: o caso de uma unidade prisional de Minas Gerais. Saúde e Sociedade, São Paulo, v. 23 , n. 4 , p. 1224-1234, out./dez.

MARZIALE, M. H. et. al. Rede de Prevenção de Acidentes de Trabalho: uma estratégia de ensino a distância. Revista Brasileira de Enfermagem, Brasília, v.63, n.2, mar./abr. 2010.

MASSAROLLO, M. D. et al. Interfaces da alimentação no sistema prisional: o caso de um Centro de Detenção e Ressocialização do Paraná. Revista Faz Ciência, Paraná, v. 14, n. 20, p. 125-151, jul./dez. 2012. 
MEIRELLES, B. H. S. et al. Percepções da qualidade de vida de pessoas com HIV/Aids. Revista Rene, Fortaleza, v. 11, n. 3, p. 68-76, jul./set. 2010.

MINAYO, M. C. S. O desafio do conhecimento: pesquisa qualitativa em saúde. 11 ed. São Paulo: Hucitec, 2008. 2002. Pesquisa social: teoria, método e criatividade. Petrópolis - Rio de Janeiro: Vozes,

MORAES, A. M.; MORAES, B. M.; RAMOS, V. M. A prática da atividade física no presídio: o que pensam os apenados? Caderno de Educação Física e Esporte, Paraná, v. 12, n. 1, p. 47-54, jan./ jun. 2014.

NASCIMENTO, A. R. A.; MENANDRO, P. R. M. Análise lexical e análise de conteúdo: uma proposta de utilização conjugada. Estudos e Pesquisa em Psicologia, Rio de Janeiro, ano 6, n.2, p. 72-88, 2006.

NICOLAU, A. I. O. et al. Retrato da realidade socioeconômica e sexual de mulheres presidiárias. Acta Paulista de Enfermagem, São Paulo, v. 25, n. 3, p. 386-392, 2012.

NUCCI, G. S. Manual de Direito Penal. 7 ed. São Paulo: Revista dos Tribunais, 2011.

OLIVEIRA, E. S. et al. Política Nacional de Promoção da Saúde e a prática de enfermagem: revisão integrativa. Revista de Enfermagem UFPE online, Recife, v. 8, n. 3, p. 735-741, mar. 2014. Disponível em:

<http://www.revista.ufpe.br/revistaenfermagem/index.php/revista/article/viewArticle/3448 $>$. Acesso em: 02 abr. 2016.

OLIVEIRA, F. S. B.; ALVES, J. S.; PAES, P. P. O exercício físico resistido como terapia não medicamentosa em pessoas que vivem com HIV/Aids e lipodistróficas. EFDeportes Revista Digital, Buenos Aires, ano 18, n. 181, jun.2013. Disponível em: <http://www.efdeportes.com/efd181/o-exercicio-fisico-resistido-em-pessoas-com-hivaids.htm>. Acesso em: 05 abr. 2016.

OLIVEIRA, L. G. D.; NATAL, S.; CAMACHO, L. A. B. O programa de controle da tuberculose em unidades prisionais de dois estados brasileiros. Caderno de Saúde Coletiva, Rio de Janeiro, v. 20, n. 2, p. 250-257, 2012.

PADOIN, S. M. M. et al. Fatores Associados à não adesão ao tratamento antirretroviral em adultos acima de 50 anos que têm HIV/Aids. DST - Jornal Brasileiro de Doenças Sexualmente Transmissíveis, Niterói, v. 23, n. 4, p. 194-197, 2011.

PARECE; M. S. et al. STD testing policies and practices in U.S. city and county jails. Sexually Transmitted Diseases, v. 26, n. 8, p. 431-437, set. 1999. Disponível em: <http://www.ncbi.nlm.nih.gov/pubmed/10494933 >. Acesso em: 15 jan. 2016. 
PEDROSA, V. L. et al. DST e suas determinantes: quatro anos de vigilância em um centro de sentinela no estado de Amazonas - Brasil. DST- Jornal Brasileiro de Doenças Sexualmente Transmissíveis, Niterói, v.23. n.2, p. 57-65, 2011.

PENDER, N. J;MURDAUGH, C. L.; PARSONS, M. A. Health promotion in nursing practice. $4^{\text {th }}$, ed. EnglewoodCliffs: Prentice Hall; 2002.

PEREIRA, H. C. D. et al. Monitoramento dos linfócitos TCD4+ de usuários com HIV/Aids de um serviço especializado de Imperatriz - MA. Revista de pesquisa: cuidado é fundamental online, Rio de Janeiro, v.4, n.3, p.2448-2457, jul./set. 2012. Disponível em: <http://www.seer.unirio.br/index.php/cuidadofundamental/article/view/1808/pdf_569>. Acesso em: 8mai. 2014.

PETROLA, L. M. et al. Presidiários masculinos e práticas sexuais: enfoque nas vulnerabilidades às doenças sexualmente transmissíveis. Revista de pesquisa: cuidado é fundamental online. Rio de Janeiro, v. 3, n. 4, p. 2473-2480, out./dez. 2011. Disponível em: 〈https://dialnet.unirioja.es/descarga/articulo/5090782.pdf >. Acesso em: 18 mar. 2016.

PÍCOLI, R. P. et al. Gestação e puerpério no cárcere: estudo descritivo da atenção à saúde. Revista Baiana de Saúde Pública, Salvador, v. 38, n. 1, p. 67-82, jul./set. 2012.

PINTO, T. et al. Benefícios do exercício físico para pacientes com HIV/AIDS. Revista HUPE, Rio de Janeiro, v. 12, n. 4, p. 18-26, out./dez. 2013.

PIRES, R. O. M. (Org.) et al. Gestão do processo de trabalho em saúde no estabelecimento penal. In: Curso de Atenção à Saúde das Pessoas Privadas de Liberdade. Santa Catarina, 2014. p. 1-43.

POLEJACK, L.; SEIDL, E. M. F. Monitoramento e adesão ao tratamento antirretroviral para HIV/Aids: desafios e possibilidades. Ciência e Saúde Coletiva, Rio de Janeiro, v. 15, supl. 1, p. 1201-1208, jun. 2010.

PRELLWITZ, I. M. et al. HIV behind bars: Human Immunodeficiency Virus cluster analysis and drug resistance in a reference correctional unit from southern Brazil. PloS One, Rio de Janeiro, v. 8, n. 7, jul. 2013. Disponível em:

<http://www.ncbi.nlm.nih.gov/pmc/articles/PMC3706441/>. Acesso em: 20 de out. 2014.

RAMJAN, R. et al. Systematic review and meta-analysis: Patient and programme impact of fixed-dose combination antiretroviral therapy. Tropical Medicine and International Health. v. 19, n. 5, p. 501-513, mai. 2014. Disponível em:

<http://www.ncbi.nlm.nih.gov/pubmed/24628918>. Acesso em: 2 mar. 2016.

RASO, V. et al. Uma breve revisão sobre exercício físico e HIV/Aids. Revista Brasileira Ciência e Movimento, São Paulo, v. 15, n. 4, p. 99-110, 2007.

REIS, C. B.; BERNARDES, É. B. O que acontece atrás das grades: estratégias de prevenção desenvolvidas nas delegacias civis contra HIV/AIDS e outras doenças sexualmente 
transmissíveis. Ciência e Saúde Coletiva, Rio de Janeiro, v. 16, n. 7, p. 3331-3338, jul. 2011 .

RODRIGUES, D. A.; TOIGO, A. M. Efeitos de diferentes tipos de exercício físico em portadores de HIV/AIDS com lipodistrofia. Revista de Atenção à Saúde, São Caetano do Sul, v. 13, n. 43, p. 73-78, jan./mar. 2015.

ROMEU, G. A. et al. Avaliação da adesão a terapia antirretroviral de pacientes portadores de HIV. Revista Brasileira de Farmácia Hospitalar e Serviços de Saúde, São Paulo, v. 3, n. 1, p. 37-41, jan./mar. 2012.

ROSA, F. et al. Prevalência de anti-HCV em uma população privada de liberdade. Revista Associação Médica Brasileira, São Paulo, v. 58, n. 5, p. 557-560, set./out. 2012.

ROSEN, D. L. et al. An evaluation of HIV testing among inmates in the North Carolina prison system. American Journal of Public Health, v.99, n. S2, p. 452-459, out. 2009. Disponível em:

<http://www.ncbi.nlm.nih.gov/pmc/articles/PMC2760001/pdf/AJPH.2007.133124.pdf >. Acesso em: 25 fev. 2016.

RUDNICKI, D. Comida e direitos humanos nos Presídio Central de Porto Alegre. Revista Direito GV, São Paulo, v. 7, n. 2, p. 515-538, jul./dez. 2011.

SALES, S. B. H. Prevalência de deficiência/insuficiência nos níveis séricos e consumo de vitamina D e cálcio em pacientes HIV. 2014. 56 f. Dissertação (Mestrado em Ciências) Faculdade de Medicina, Universidade de São Paulo, São Paulo, 2014. Disponível em: $<$ http://www.teses.usp.br/teses/disponiveis/5/5133/tde-20012015-154835/pt-br.php >. Acesso em: 5 abr. 2016.

SANCHEZ, A. R. et al. A tuberculose nas prisões do Rio de Janeiro, Brasil: uma urgência de saúde pública. Caderno de Saúde Pública, Rio de Janeiro, v. 23, n. 3, p. 545-552, mar. 2007.

Screening for tuberculosis on admission to highly endemic prisons? The case of Rio de Janeiro State prisons. The International Journal of Tuberculosis and Lung Diseases, v. 13, n. 10, p. 1247-1252, out. 2009. Disponível em:

<http://www.ncbi.nlm.nih.gov/pubmed/19793429>. Acesso em: 23 fev. 2016.

SANTOS, B. F. O.; SANTANA, N. O.; FRANCA, A. V. C. Prevalence, genotypes and factors associated with HCV infection among prisoners in Northeastern Brazil. World Journal of Gastroenterology, v. 17, n. 25, p. 3027-3034, jul. 2011. Disponível em: <http://www.ncbi.nlm.nih.gov/pmc/articles/PMC3132254/>. Acesso em: 22 mar. 2016.

SANTOS, F. B.; SEIDL, E. M. F. Caracterização de pessoas com HIV/Aids em abandono do tratamento antirretroviral e a busca consentida de casos. Brasília Médica, Brasília, v. 48, n. 3, p. 268-276, 2011. 
SANTOS, I. et. al. O grupo pesquisador construindo ações de autocuidado para o envelhecimento saudável: pesquisa sociopoética. Escola Anna Nery Revista de Enfermagem, Rio de Janeiro, v.15, n.4, p. 746-754, out./dez. 2011.

SANTOS, W. J. et al. Barreiras e aspectos facilitadores da adesão à terapia antirretroviral em Belo Horizonte - MG. Revista Brasileira de Enfermagem, Brasília, v. 64, n. 6, p. 10281037, nov./dez. 2011.

SENA, E. A.; FREITAS, C. H. S. M.; PONTES, A. L. S. O papel do nutricionista na atenção aos portadores do HIV/Aids no sistema penitenciário brasileiro: uma revisão de literatura. Revista Brasileira de Ciências da Saúde, Paraíba, v. 18, supl. 2, p. 169-178, 2014.

SILVA, A. A. A. et al. Prevalência de má nutrição e doenças oportunistas em pacientes HIV/Aids internados em um hospital referência em Porto Velho - Rondônia. Revista Saber Científico. v. 4, n. 1, p. 80-88, 2015.

SILVA, A. C. S.; SANTOS, I. Promoção do autocuidado de idosos para o envelhecer saudável: aplicação da teoria de Nola Pender. Texto e Contexto Enfermagem, Florianópolis, v.19, n.4, p.745-753, out./dez. 2010.

. BERARDINELLI, L. M. M. A imagem corporal do idoso no reflexo do autocuidado no envelhecimento saudável: estudo sociopoético. Online Brazilian Journal of Nursing, Niterói, v.9, n.1, abr. 2010. Disponível em:

<http://www.objnursing.uff.br/index.php/nursing/article/view/j.1676-4285.2010.2779/612>. Acesso em: 30 jan. 2016.

Promovendo autocuidado em clientes com obesidade e coronariopatia: aplicação do diagrama de Nola Pender. Revista de Enfermagem da UERJ, Rio de Janeiro, v.21, n.3, p.301-306, jul./set. 2013.

SILVA, E. F. R. et al. Estado nutricional, clínico e padrão alimentar de pessoas vivendo com HIV/Aids em assistência ambulatorial no município de São Paulo. Revista Brasileira de Epidemiologia, São Paulo, v. 13, n. 4, p. 677-688, dez. 2010.

SILVA; E. L. A realidade do sistema penitenciário brasileiro e o princípio da dignidade da pessoa humana. 2013. Disponível em:

<http://www.egov.ufsc.br/portal/conteudo/realidade-do-sistema-penitenci\%C3\%A1riobrasileiro-e-o-princ\%C3\%ADpio-da-dignidade-da-pessoa-humana $>$. Acesso em: 30 mar. 2016.

SILVA, I. R. P. et al. Dislipidemia e estado nutricional em pacientes HIV positivo com síndrome lipodistrófica. Revista de Epidemiologia e Controle de Infecção, Santa Cruz do Sul, v. 4, n. 3, p. 200-207, jul./set. 2014.

SILVA, M. C. A.; BURGOS, M. G. P. A.; SILVA, R. A. Alterações nutricionais e metabólicas em pacientes com Aids em uso de terapia antirretroviral. DST - Jornal 
Brasileiro de Doenças Sexualmente Transmissíveis, Rio de Janeiro, v. 24, n. 4, p. 233-238, 2012.

SILVA, R. C.N. et al. Abuso de drogas: relação entre hepatite C e co-infeccção com HIV. Revista Saúde e Pesquisa, Maringá, v.8, n. 1, p. 141-148, jan./abr. 2015.

SILVA; T. A. O sistema carcerário brasileiro: não ressocialização, o desrespeito aos direitos humanos e a superlotação. 2014. Disponível em:

<https://jus.com.br/artigos/29690/o-sistema-carcerario-brasileiro-nao-ressocializacao-odesrespeito-aos-direitos-humanos-e-a-superlotacao>. Acesso em: 30 mar. 2016.

SOUSA, C. S. O.; SILVA, A. L. O cuidado a pessoas com HIV/aids na perspectiva de profissionais de saúde. Revista Escola de Enfermagem da USP, São Paulo, v. 47, n. 4, p. 907-914, 2013.

SOUSA, P. K. R.; MIRANDA, K. C. L.; FRANCO, A. C. Vulnerabilidade: análise do conceito na prática clínica do enfermeiro em ambulatório de HIV/AIDS. Revista Brasileira de Enfermagem, Brasília, v. 64, n. 2, p. 381-384, mar./abr. 2011.

SOUZA, K. M. J. et al. Atraso do diagnóstico da tuberculose em sistema prisional: a experiência do doente apenado. Texto \& Contexto Enfermagem, Florianópolis, v. 21, n. 1, p. 17-25, jan./mar. 2012.

SOUZA, M. L. et al. O cuidado em enfermagem - uma aproximação teórica. Texto \& Contexto Enfermagem, Florianópolis, v. 14, n. 2, p. 266-270, abr./jun. 2005.

SOUZA, M. O. S.; PASSOS, J. P. A prática de enfermagem no sistema penal: limites e possibilidades. Escola Anna Nery Revista de Enfermagem, Rio de Janeiro, v. 12, n. 3, p. 417-423, set. 2008.

SPAULDING, A. C. et al. Diversity of release patterns for jail detainees: Implications for public health interventions. American Journal of Public Health, v. 101, n. S1, dez. 2011. Disponível em: <http://ajph.aphapublications.org/doi/pdf/10.2105/AJPH.2010.300004>. Acesso em: 6 fev. 2016.

Small reservoirs: jail screening for gonorrhea and Chlamydia in low prevalence areas. Journal of Correctional Health Care, v. 15, n. 1, p. 28-34, jan. 2009. Disponível em: <http://www.ncbi.nlm.nih.gov/pubmed/19477809>. Acesso em: 22 fev. 2016.

STRAZZA, L. et al. Estudo de comportamento associado à infecção pelo HIV e HCV em detentas de um presídio feminino de São Paulo, Brasil. Caderno de Saúde Pública, Rio de Janeiro, v. 23 n. 1, p. 197-205, jan. 2007.

SUCUPIRA, A. C.; MENDES, R. Promoção da Saúde: conceitos e definições. SANARE Revista de Políticas Públicas, Sobral, ano IV, n. 1, p. 7-10, jan./mar. 2003. 
TOMEY, A. M.; ALLIGOOD, M. R. Teóricas de Enfermagem e sua Obra: modelos e teorias de enfermagem. $5^{\text {a }}$ edição. Portugal: Lusociências, 2004. Cap. 33 (699-715).

TURATO, E. R. Métodos qualitativos e quantitativos na área da saúde: definições, diferenças e seus objetos de pesquisa. Revista de Saúde Pública, São Paulo, v.39, n.3, p. 507-514, 2005.

UNAIDS. HIV/Aids em ambientes prisionais: prevenção, atenção, tratamento e apoio marco referencial para uma resposta nacional eficaz. Viena. 2007. 52p.

Informações básicas. Disponível em: <http://unaids.org.br/informacoes-basicas/.

Acesso em: 10 fev. 2016.

VALENTE, G. S. C.; SANTOS, F. S. A complexidade do trabalho de enfermagem no hospital de custódia e tratamento psiquiátrico. Revista de pesquisa: cuidado é fundamental online, Rio de Janeiro, v. 6, n. 1, p. 109-117, jan./mar. 2014. Disponível em: <http://www.seer.unirio.br/index.php/cuidadofundamental/article/view/2871/pdf_1098 $>$. Acesso em: 19 jan. 2016.

VARELLA, D. Estação Carandiru. 2ª ed. São Paulo, SP: Companhia das Letras, 2009. 295p.

VESCIO, M. F. et al. Correlates of hepatitis C virus seropositivity in prison inmates: a metaanalysis. Journal of Epidemiology \& Community Health, v. 62, n. 4, p. 305-313, abr. 2008. Disponível em:

<http://www.ncbi.nlm.nih.gov/pubmed/18339822>. Acesso em: 15 jan. 2016.

VICTOR, J. F.; LOPES, M. V.O.; XIMENES, L. B. Análise do diagrama do modelo de promoção da saúde, de Nola J. Pender. Acta Paulista de Enfermagem, São Paulo, v. 18, n. 3, p. 235-240, 2005.

WALDOW, V. R.; LOPES, M. J. M.; MEYER D. E. Maneiras de cuidar, maneiras de ensinar. Porto Alegre: Artes Médicas; 1998.

WEINBAUM, C. M.; SABIN, K.; SANTIBANEZ, S. Hepatitis B, hepatitis C, and HIV in correctional populations: a review of epidemiology and prevention. Official Journal of the International Aids Society - AIDS, v. 19, n. S3, p. 41-46, out. 2005. Disponível em: <http://www.ncbi.nlm.nih.gov/pubmed/16251827>. Acesso em: 21 jan. 2016.

WORLD HEALTH ORGANIZATION. 10 facts on sexually transmitted infections. 2008. Disponível em: <http://www.who.int/features/factfiles/sexually_transmitted_diseases/en/>. Acesso em: 15 mar. 2016.

HIV/Aids. 2015. Disponível em:

<http://www.who.int/mediacentre/factsheets/fs360/en/>. Acesso em: 04 fev. 2016. 
WORLD HEALTH ORGANIZATION. Sexually transmitted infections. 2015. Disponível em: 〈http://www.who.int/mediacentre/factsheets/fs110/en/>. Acesso em: 15 mar. 2016. 


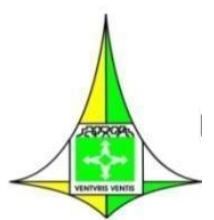

\section{APÊNDICE 1 \\ GOVERNO DO DISTRITO FEDERAL \\ SECRETARIA DE ESTADO DE SAÚDE}

Fundação de Ensino e Pesquisa em Ciências da Saúde

Comitê de Ética em Pesquisa

ROTEIRO PARA ENTREVISTA SEMIESTRUTURADA

Data: ...................

Inicio:

hs

Término: hs

\section{A) PERFIL SOCIO-DEMOGRÁFICO}

1- Identificação:

2- Idade:

3- Profissão/Ocupação

4- Estado civil

5- Escolaridade

6- Crença religiosa

7- Orientação sexual.

8- Anos de reclusão:

\section{B) SITUAÇÃo DE SAÚDE}

\section{CARACTERÍSTICAS E FATORES INDIVIDUAIS}

\subsection{Fatores Pessoais}

Exame positivo para HIV: ....../....../.....

Outra doenças?

Você sabe como contraiu o HIV? ( ) Sim ( ) ) Não

Condição (no caso de resposta afirmativa).

Usa de antirretrovirais?( ) Sim ( ) Não

Caso afirmativo quais? 
Você usa os antirretrovirais conforme lhe foi orientado?

( ) Sim ( ) Não Por que?

Teve alguma doença durante o cumprimento da pena? ( ) Sim ( ) Não

Se sim, qual (is): ( ) Tuberculose

$$
\begin{aligned}
& \text { ( ) Pneumonia } \\
& \text { ( ) Meningite } \\
& \text { ( ) Outras ......... }
\end{aligned}
$$

Já recebeu orientações de como promover a sua saúde? Quais? De Quem?

\subsection{Comportamento anterior}

a) Antes de saber ser portador de HIV/Aids, como eram seus comportamentos relacionados a: - Atividades sexuais

- Doenças Sexualmente Transmissíveis

-Uso de drogas

b) Descreva as medidas gerais (cuidados) para a promoção da saúde que você tomava antes de saber que era portador de HIV/Aids, ou seja, o que você fazia para se manter saudável e evitar doenças.

\section{COMPORTAMENTO ESPECÍFICO ATUAL}

(levando em consideração a sua atual condição de saúde e a sua situação de encarceramento)

\subsection{Comportamentos de promoção de saúde atual (hábitos de vida)}

O que você faz hoje para se manter saudável e sem problemas de doenças e outras complicações de saúde? 
2.2 Como você percebe a importância dessas práticas de promoção da saúde?

- Benefícios destes comportamentos:

- Barreiras/Dificuldades para estes comportamentos:

- Influências pessoais (É influenciado por alguém?)

- Situações que influenciam

\section{RESULTADO DO COMPORTAMENTO E EXPERIÊNCIAS INDIVIDUAIS}

3.1 Fale sobre hábitos e condições do ambiente que você acha importante para manter uma vida saudável, considerando a sua condição de portador de HIV em privação de liberdade. 

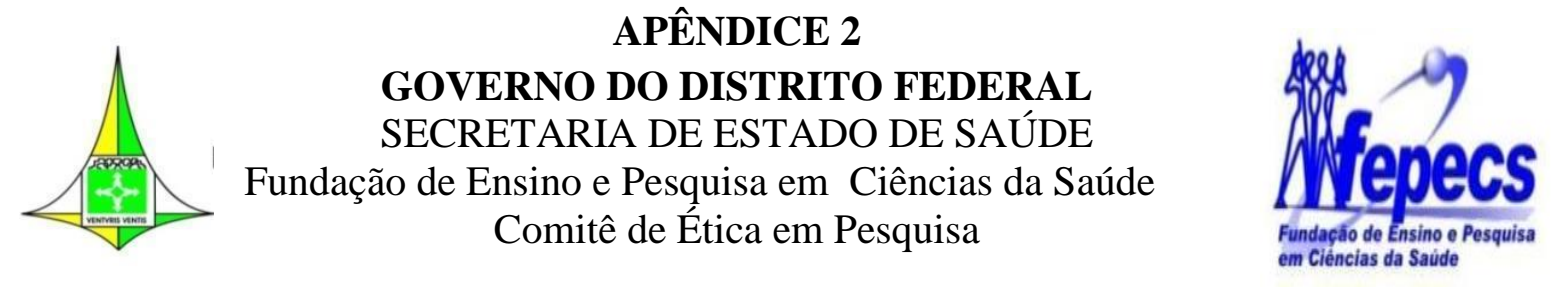

TERMO DE CONSENTIMENTO LIVRE E ESCLARECIDO - TCLE

O senhor está sendo convidado a participar do projeto: "A promoção da saúde dos portadores de HIV/Aids: um estudo no Complexo Penitenciário do Distrito Federal Papuda". O nosso objetivo é investigar comportamentos de promoção da saúde das pessoas privadas de liberdade portadoras de HIV/Aids no Complexo Penitenciário do Distrito Federal - Papuda.

O senhor receberá todos os esclarecimentos necessários antes e no decorrer da pesquisa e lhe asseguramos que seu nome não aparecerá, sendo mantido o mais rigoroso sigilo pela omissão total de quaisquer informações que permitam identificá-lo.

A sua participação será por meio de um questionário que você deverá responder no setor de saúde desta penitenciária, na data combinada com um tempo estimado para seu preenchimento de 60 minutos. Não existe obrigatoriamente, um tempo pré-determinado para responder o questionário. Será respeitado o tempo de cada um para respondê-lo. Informamos que o senhor pode se recusar a responder qualquer questão que lhe traga constrangimento, podendo desistir de participar da pesquisa em qualquer momento sem nenhum prejuízo para o senhor.

Os resultados da pesquisa serão divulgados aqui no Complexo Penitenciário do Distrito Federal - Papuda, podendo ser publicados posteriormente. Os dados e materiais utilizados na pesquisa ficarão sobre a guarda do pesquisador.

Se o senhor tiver qualquer dúvida em relação à pesquisa, por favor, entre em contato com a equipe de saúde desta penitenciária, na Gerência de Assistência ao Interno - GEAIT, no horário de 09:00 às 16:00 h, de segunda a sexta-feira.

Este projeto foi Aprovado pelo Comitê de Ética em Pesquisa da SES/DF (CEP/Fepecs), sob o número de Protocolo 027867/2015. As dúvidas com relação à assinatura 
do TCLE ou os direitos do sujeito da pesquisa podem ser obtidos pelo telefone: (61) 33254955.

Este documento foi elaborado em duas vias, uma ficará com o pesquisador responsável e a outra com o sujeito da pesquisa.

Nome / assinatura:

Pesquisador Responsável

Nome e assinatura:

Brasília, __ de ____ de __ 


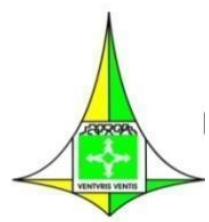

\section{ANEXO 1 \\ GOVERNO DO DISTRITO FEDERAL \\ SECRETARIA DE ESTADO DE SAÚDE}

Fundação de Ensino e Pesquisa em Ciências da Saúde

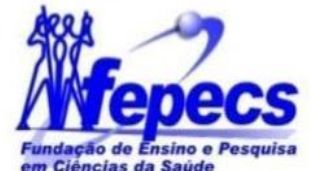

Comitê de Ética em Pesquisa

\section{PARECER CONSUBSTANCIADO DO CEP/FEPECS}

\section{COMITÊ DE ÉTICA EM PESQUISA - FEPECS/SES-DF}

\section{PARECER CONSUBSTANCIADO DO CEP}

\section{DADOS DO PROJETO DE PESQUISA}

Título da Pesquisa: A promoção da saúde dos portadores de HIV/Aids: um estudo no Complexo Penitenciário do Distrito Federal - Papuda

Pesquisador: Henrique Coimbra Guimarães

Área Temática:

Versão: 2

CAAE: 43761015.5 .0000 .5553

Instituição Proponente: Diretoria Regional de Saúde de São Sebastião

Patrocinador Principal: Financiamento Próprio

\section{DADOS DO PARECER}

Número do Parecer: 1.129.067

Data da Relatoria: 29/06/2015

\section{Apresentação do Projeto:}

O vírus da imunodeficiência humana - HIV é um retrovirus que tem como uma de suas principais propriedades a infecção de células do sangue e supressão do sistema imunológico. A Síndrome da Imunodeficiência Adquirida - Aids é a doença causada pelo vírus HIV devido à deterioração progressiva do sistema imune, ocasionando infecções oportunistas, como pneumonia, tuberculose e meningite, que podem levar ao óbito. Diante da situação epidemiológica do HIV/Aids no Brasil e no mundo, nenhuma doença exigiu tanto envolvimento de organizações governamentais e não governamentais, mobilizando a sociedade sob diversos aspectos.

Estudos realizados em 10 municípios brasileiros entre 2008 e 2009 estimaram taxas de prevalência de HIV de $5,9 \%$ entre usuários de drogas, de $10,5 \%$ entre homens que fazem sexo com homens e de $4,9 \%$ entre mulheres profissionais do sexo. Dessa forma, evidencia-se que a epidemia do HIV no Brasil possui maior prevalência em populações que vivem em situações de risco e de maior vulnerabilidade, caracteristicas estas bem peculiares à população privada de liberdade, já que nos presídios há uma heterogeneidade da população confinada, o que consequentemente estimula práticas que aumentam o risco de transmissão de doenças infecciosas tanto pelos comportamentos sexuais inadequados como pelo uso de drogas. 


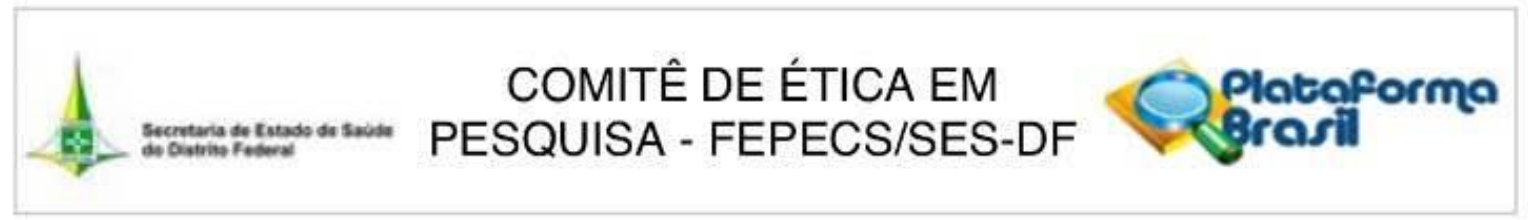

Continuaçắo do Parecer: 1.129 .067

\section{Objetivo da Pesquisa:}

Geral:

- Investigar comportamentos de promoção da saúde das pessoas privadas de liberdade portadoras de HIV/Aids no Complexo Penitenciário do Distrito Federal - Papuda.

\section{Específicos:}

- Identificar as características sócio demográficas e perfil psicossocial dos portadores de HIV/Aids do Complexo Penitenciário da Papuda;

- Descrever a vivência dos internos do Complexo Penitenciário da Papuda no convivio com a doença HIV/Aids;

- Analisar os relatos e experiências dos detentos sobre ser portador do HIV/Aids, com ênfase na adoção de comportamentos de promoção da saúde, como alimentação, atividade física, doenças oportunistas, internações e acesso aos serviços de saúde.

\section{Avaliação dos Riscos e Benefícios:}

Os sujeitos foram adequadamente identificados. Foram apresentados os riscos e benefícios. Com os benefícios, espera-se possibilitar, planejar e implementar intervençōes de saúde para que os sujeitos do estudo possam viver com maior qualidade de vida. Os antecedentes científicos que justificam a pesquisa foram apresentados.

\section{Comentários e Considerações sobre a Pesquisa:}

A pesquisa refere-se ao Mestrado em Enfermagem. Trata-se de um estudo caráter descritivo, de abordagem qualitativa, exploratório. A pesquisa será realizada no Complexo Penitenciário do Distrito Federal - Papuda, localizado na região administrativa de São Sebastião/DF. Para o referido estudo serão entrevistados 13 pacientes portadores de HIV/Aids que estão sob regime fechado de detenção, alojados no PDF II (Penitenciária do Distrito Federal

II), o que representa no momento $20,3 \%$ da população total de PVHA (pessoa que vive com HIV/Aids).

Para a coleta de dados serăo utilizados dois instrumentos: o primeiro visa traçar o perfil sócio-demográfico dos sujeitos do estudo e o segundo consistirá em entrevista semiestruturada onde os sujeitos serão incentivados a falar sobre a sua situação atual de saúde enquanto portadores do HIV/Aids e institucionalizados, focando o impacto deste como fator predisponente para a adoção de comportamentos de promoçăo da saúde.

As entrevistas serão gravadas em aparelho digital, ressaltando que a participação na pesquisa é 


\section{COMITÊ DE ÉTICA EM PESQUISA - FEPECS/SES-DF}

Continuação do Parecer: 1.129.067

voluntária e, portanto, não implicará em redução de pena, indulto ou qualquer beneficio ou prejuizo à pessoa".

Os dados serão analisados pelo método de análise de conteúdo (AC).

\section{Considerações sobre os Termos de apresentação obrigatória:}

Folha de Rosto: Apresentada. Documento assinado pelo Coordenador Geral de Saúde SAS/SES/DF.

Termo de Concordância: Apresentado. Documento assinado pelo Diretor Regional de Saúde de São Sebastião e pela Chefia da Unidade Clínica da Penitenciária do DF.

Termo de Anuência da Instituição: Apresentado. Documento assinado pelo Diretor Geral do Presídio PDF II. Curriculum Vitae do(s) pesquisador(es): Apresentados.

Cronograma da Pesquisa: Apresentado.

TCLE: Apresentado.

Metodologia: Apresentado.

Critérios de Inclusão e Exclusāo: Definidos.

\section{Recomendações:}

O pesquisador assume o compromisso de garantir o sigilo que assegure $o$ anonimato e a privacidade dos sujeitos da pesquisa e a confidencialidade dos dados coletados. Os dados obtidos na pesquisa deverão ser utilizados exclusivamente para a finalidade prevista no seu protocolo, que só poderá iniciar após aprovação pelo CEP/FEPECS/SES/DF.

O pesquisador deverá encaminhar relatório parcial e final de acordo com o desenvolvimento do projeto da pesquisa.

Conclusões ou Pendências e Lista de Inadequações:

- Projeto Aprovado.

Situação do Parecer:

Aprovado

Necessita Apreciação da CONEP:

Não

Consideraçōes Finais a critério do CEP: 